\title{
Trophic Ecology of the Cuban Boa, Chilabothrus angulifer (Boidae)
}

Tomás M. Rodríguez-Cabrera ${ }^{1}$, Ernesto Morell Savall ${ }^{2}$, Sheila Rodríguez-Machado ${ }^{3}$, and Javier Torres $^{4}$

${ }^{1}$ Sociedad Cubana de Zoología, Cuba (tomasmichel.rodriguez@gmail.com)

${ }^{2}$ Edificio 4, Apto 7, e/ Oquendo y Silverio, Rpto Virginia, Santa Clara, Villa Clara 50100. Cuba (ernestomorell68@nauta.cu)

${ }^{3}$ Department of Biological Sciences, Museum of Natural Sciences, Louisiana State University, 119 Foster Hall, Baton Rouge, Louisiana 70803, USA

(sheilaroma89@gmail.com)

${ }^{4}$ Department of Ecology and Evolutionary Biology, University of Kansas, Lawrence, Kansas 66045, USA (javiertorres@ku.edu)

\begin{abstract}
The Cuban Boa (Chilabothrus angulifer) is a top terrestrial predator in Cuba. References to prey species consumed by this boa date to when the first Europeans arrived in the region more than 500 years ago. However, longterm studies on its trophic ecology do not exist. The scarce and scattered records on its feeding habits indicate that this boa preys on a variety of native and domestic animals. Based on dietary information collected in the field and from the literature, we characterized the diet of this snake and tested four different hypotheses: (1) The Cuban Boa is a generalist predator; (2) the diets of boas in natural and anthropogenic habitats differ; (3) an ontogenetic shift in diet occurs; and (4) foraging strategies used in natural and anthropogenic habitats differ. We identified 49 prey species from 351 prey items obtained from 218 snakes, including 71 items (31 snakes) from the literature. Mammals represented 55\% of total prey items consumed, followed by birds (41\%) and ectotherms (4\%). Chilabothrus angulifer exhibited a narrow niche breadth. However, rather than a trophic specialist, we consider this boa an opportunistic generalist predator, capable of adjusting its diet and foraging behavior according to prey availability and abundance. The diet of Ch. angulifer changed dramatically from mostly native mammals and birds in natural habitats to mostly livestock, pets, and human commensals in human-altered habitats. Also, mammals were consumed more frequently in natural habitats, whereas birds dominated the diet of boas associated with anthropogenic habitats. Few ectotherms were consumed in either type of habitat. We observed an ontogenetic shift in diet, but this primarily reflected a trend of consuming larger prey rather than a shift from ectotherms to endotherms as reported for some other boids. In natural habitats, Ch. angulifer used both ambush and active-foraging modes by day and night, whereas in anthropogenic situations, most boas used an active-foraging strategy at night. The frequent consumption of domestic animals by Cuban Boas might be the principal reason for the historical human-wildlife conflict involving this species in rural areas of Cuba.
\end{abstract}

$\mathrm{H}_{\text {leasen }}^{\text {un }}$ uman-wildlife conflicts pose one of the greatest challenges in biodiversity conservation (Conover 2001; Decker et al. 2002; Anthony et al. 2010; Manral et al. 2016). Large constrictors (Boidae, Pythonidae) are among the top predators in many ecosystems. Their large size and muscular strength allow them to exploit a wide variety of prey, ranging from small ectotherms and endotherms to relatively large prey such as alligators, capybaras, monkeys, artiodactyls, and even hyenas, bears, and leopards (Murphy and Henderson 1997; Rivas 2000; Fredriksson 2005; Reed and Rodda 2009; Monroy-Vilchis et al. 2011; Greshko 2017). With the continuous development of human settlements, many large snakes have been forced to coexist with humans in a different structural habitat with a different associated fauna (Shine and Fitzgerald 1996; Fearn et al. 2001; Luiselli et al. 2001; Pearson et al. 2005; Tolson and Henderson 2006). The occurrence of these large predators in urban areas increases the probability of predation on domestic animals that are important to human wellbeing (Fearn et al. 2001; Tolson and Henderson 2006; Reed and Rodda 2009; RodríguezCabrera et al. 2016a). Such interactions often are responsible for human-wildlife conflicts that are pushing many large constrictors to the edge of extinction (IUCN 2020).

With a snout-vent length (SVL) that can exceed $5.0 \mathrm{~m}$ and a mass of more than $30 \mathrm{~kg}$ (Gundlach 1880; Tolson and Henderson 1993; Petersen et al. 2015; Rodríguez-Cabrera et al. 2016a; T.M. Rodríguez-Cabrera, unpubl. data), the Cuban Boa (Chilabothrus angulifer) (Fig. 1) is the largest snake in the West Indies. This species is endemic to the Cuban Archipelago, where it is widely distributed on the main island, Isla de la Juventud, and some adjacent cays, where it inhabits a variety of environments at elevations from 


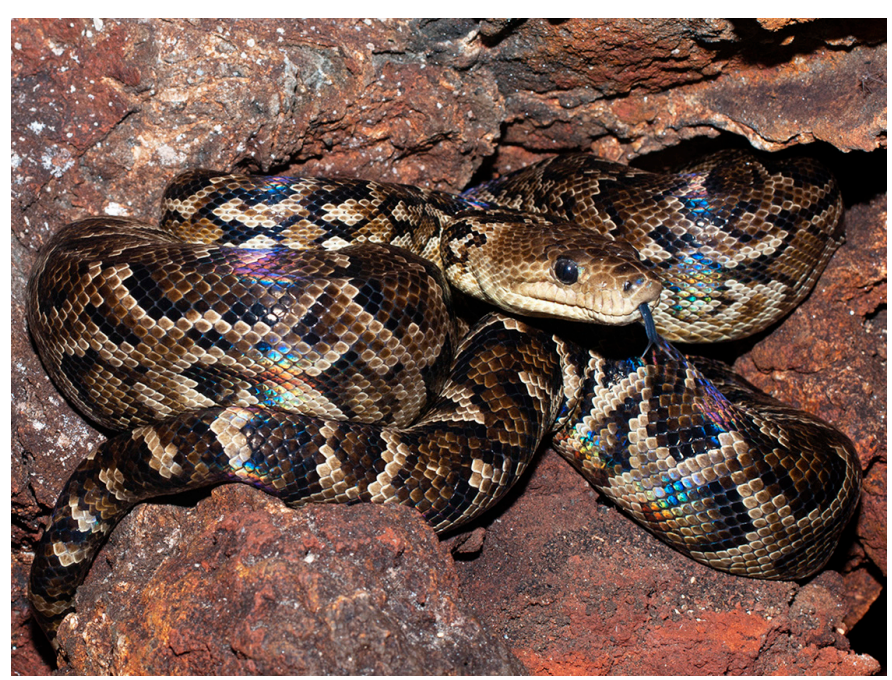

Fig. 1. The Cuban Boa (Chilabothrus angulifer) is the largest and stoutest snake in the West Indies. Photograph (C) Raimundo López-Silvero.

sea level to above 1,200 m (Tolson and Henderson 1993, 2006; Henderson and Powell 2009; Rodríguez et al. 2010, 2013; Estrada 2012; Marichal 2016). Chilabothrus angulifer is a top predator in Cuban terrestrial ecosystems (Petersen et al. 2007, 2015; Rodríguez-Cabrera et al. 2016a). The long history of deforestation in Cuba, mostly as a consequence of the extensive development of the sugar industry and stockbreeding, resulted in an approximately $90 \%$ reduction of forest coverage between the 16th and mid-20th centuries (Capote et al. 1989; del Risco 1989, 1995; Gutiérrez-Domech and Rivero-Glean 1997; Funes 2004). This likely forced many boas to abandon natural habitats in search of alternative prey (e.g., domestic animals), increasing the frequency and intensity of conflicts with humans. In fact, multiple references to human-boa conflicts have been documented in the literature since the 19th century (Appendix I).

Chilabothrus angulifer may be locally common in a few remaining natural habitats (Berovides and Carbonell 1998; Linares et al. 2011; Rodríguez-Cabrera et al. 2015). Aggregations of nearly 30 boas have been repeatedly reported in natural sites with large concentrations of food resources, especially bat caves (Berovides and Carbonell 1998). However, when analyzing the relative abundance of $C h$. angulifer on a wider geographical scale, the species is uncommon. Populations of Ch. angulifer in natural habitats other than bat caves (e.g., karstic woodlands, grasslands, wetlands) appear to be much smaller and dispersed (Tolson and Henderson 2006; P.J. Tolson, in litt. 2008; T.M. Rodríguez-Cabrera, pers. obs.). However, studies on the ecology of this boa are few and almost exclusively focused on cave-associated populations (Alfonso et al. 1998; Berovides and Carbonell 1998; Morell et al. 1998; Linares et al. 2011; Rodríguez-Cabrera et al. 2015; Dinets 2017). The exception is a still-unpublished long-term field research project led by Peter J. Tolson on the grounds of the U.S. Naval Base at Guantánamo Bay (Tolson and Henderson 2006; Petersen et al. 2007, 2015; P.J. Tolson in Henderson and Powell 2009; Meeks 2018).

The available data suggest that $C h$. angulifer preys on a wide variety of animals that includes reptiles, native birds, bats, hutias, introduced murid rodents, and domestic animals (Appendix I). Herein, we test the hypothesis that $C h$. angulifer is a generalist predator and predict that this boa has a wide dietary niche breadth.

Even if a given species is a trophic generalist or specialist, its diet may be constrained by the abundance and composition of available dietary resources. Specifically, species assemblages and their relative abundances differ considerably between natural and anthropogenic habitats (Estrada et al. 1997; Tews et al. 2004; Gamage et al. 2011). Therefore, the expectation that prey in natural habitats will differ from that in human-altered habitats is reasonable. We also test the hypothesis that the diet of Ch. angulifer in natural habitats differs from that of boas in anthropogenic habitats and predict that both prey composition and relative abundance in the diet of snakes occurring in natural habitats are different than those in the diet of snakes associated with human-altered habitats.

Another factor that can constrain the types of prey consumed is the size of the snake. Snakes are gape-limited predators because they swallow their prey whole; hence, gape size sets an upper limit to prey size (Shine 1991; Forsman 1996; Rodríguez-Robles et al. 1999; Vincent et al. 2004, 2005; Hampton 2014). Medium-sized to large adult boas and pythons may be more than an order of magnitude larger than neonates of the same species (Henderson et al. 1987; Tolson and Henderson 1993; Rivas 2000; Pizzatto and Marques 2007; Reed and Rodda 2009). Therefore, these snakes typically exhibit an ontogenetic shift in diet. An initial shift usually involves a transition from ecto- to endothermic prey and then a second more gradual shift involves a transition from smaller to larger endothermic prey (Henderson et al. 1987; Harlow and Shine 1992; Henderson 1993; Fearn et al. 2001; Pizzatto et al. 2009; Henderson and Pauers 2012). Due to the great difference in size between neonatal and adult $C h$. angulifer, we test the hypothesis that an ontogenetic shift in diet occurs in this species and predict that prey type and size changes as snakes grow.

Snakes may use sit-and-wait and/or active foraging strategies in response to a number of biotic and abiotic factors (Huey and Pianka 1981; Mushinsky 1987). Habitat structure and the characteristics and accessibility of available prey can influence the strategy employed (Mushinsky 1987; Lind and Welsh 1994; Secor 1995; Mullin and Cooper 2000; Beaupre and Montgomery 2007; Emmons et al. 2016). We test the hypothesis that the foraging strategy used by $C h$. angulifer differs in natural versus anthropogenic habitats and predict that the frequency of foraging modes will be different. 


\section{Materials and Methods}

Data collection.-We collected data from four different sources: direct field observations over a span of more than 30 years (1987-2020), the literature, unpublished data provided by colleagues, and testimonies from trustworthy farmers and/or local land owners. To the best of our knowledge, we screened all of the available scientific literature related to the natural history and diet of $C h$. angulifer since the first mention of the species in the 16th century. We chose specific descriptions of predation over accounts that were anecdotal, repetitive, or speculative. Compelling data were in about 20 different publications, most of which described isolated predation events (Appendix I). Most of the data originated from about 30 montane and lowland localities in central Cuba (Cienfuegos, Villa Clara, and Sancti Spíritus Provinces) (Fig. 2). However, we also included relevant information from more than 25 additional localities in other provinces across the country. Most localities are represented by single events (i.e., one boa), but multiple cases came from a few localities (e.g., Cariblanca, Sancti Spíritus Province, and San Blas village and vicinity in the Guamuhaya Massif, Cienfuegos Province).

The data gleaned from the literature were in some cases insufficient for the purposes of this work. Therefore, we verified and enhanced them with additional information by establishing direct communication with the respective authors when possible (Appendix I). In the case of the Whitecrowned Pigeon (Patagioenas leucocephala), we were unable to obtain any additional quantitative data. Therefore, this species was included in the total number of species consumed by Ch. angulifer, but not in the statistical analyses.

Many snakes encountered in the field had a visible bulge in the stomach. To avoid killing the snake, we used forced regurgitation by palpation of the abdomen in order to obtain the dietary information (Luiselli and Amori 2016). We quan- tified and identified the prey items to the lowest taxonomic resolution possible, and assigned each to one of three categories (i.e., egg, juvenile or adult). Zoological nomenclature followed the most recent compilations for each group: amphibians (AmphibiaWeb 2020; Hedges et al. 2019), reptiles (Uetz et al. 2020; Hedges et al. 2019), birds (Navarro 2020), and mammals (Mammal Diversity Database 2020). Many feeding events witnessed were incidental to other work, which sometimes precluded determination of an accurate weight for the prey item. In such situations or when prey items were in advanced states of digestion, we extrapolated the average prey mass from fresh conspecific individuals of equivalent size or assumed a mean mass for the species based on the literature (Silva 1979; Sampedro and Montañez 1989; Silva et al. 2007; Jiménez et al. 2014; Sibley 2017). When possible, we measured the SVL of snakes to the nearest centimeter using the string method (Rivas et al. 2008) but, in some cases, we visually estimated total length. Cuban Boas have relatively short tails averaging only about $10 \%$ of total length (T.M. Rodríguez-Cabrera, unpubl. data). Thus, we assumed that our visual estimates of total length approximated SVL.

Hypothesis testing.- - To test the hypothesis that Ch. angulifer is a generalist predator, we calculated its trophic niche breadth (Krebs 1998) using the standardized version of Levins' (1968) niche breadth (Hurlbert 1978):

$$
B^{\prime}=\frac{B-1}{n-1} \quad B=\frac{1}{\Sigma p_{j}{ }^{2}}
$$

where $B^{\prime}$ is the standardized version of Levins' niche breadth, $B$ is Levins' measure of niche breadth, $n$ is the number of possible resource states, and $p_{j}$ is the proportion of individuals found using resource state $j$. Levins' standardized niche breadth ranges from 0 to 1 . This index reaches a maximum

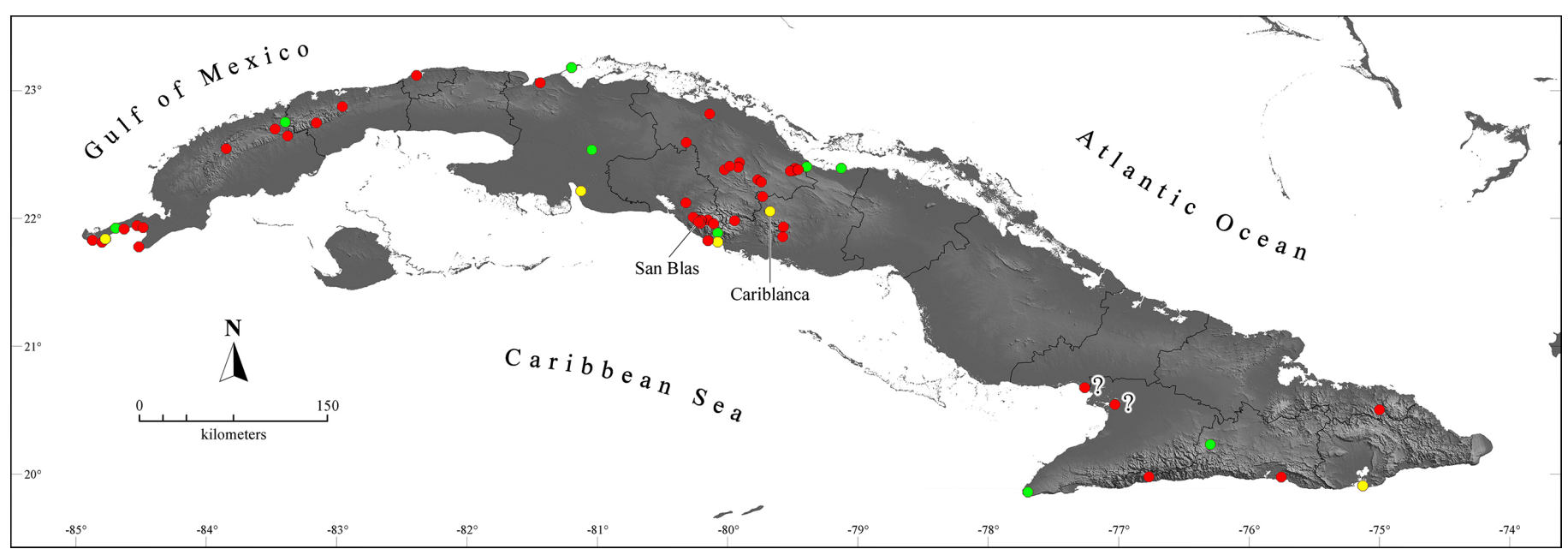

Fig. 2. Localities where predation events by Cuban Boas (Chilabothrus angulifer) have been reported, including records from the literature (green dots), records from this work (red dots), and both (yellow dots). Labels indicate localities with the highest numbers of predation events. The dots with question marks represent locations in southern Las Tunas Province (left) and in the "Wiso Colony" (right) where boas with visible stomach bulges have been observed associated with bird-nesting colonies in mangroves. 
when each resource state is used by a similar number of individuals in proportion to its abundance, which means that the species does not discriminate between one resource state or another. It reaches a minimum when only a single resource state is used by all individuals, reflecting the narrowest possible niche and hence maximum specialization. We grouped prey items into 16 resource states according to similarities in body shape, size, and/or ecological features (i.e., anurans, lizards, snakes, turtles, aquatic birds [Gruiformes], free-ranging raptors [Accipitriformes, Cathartiformes], forest birds [Columbiformes, Cuculiformes, Passeriformes], caged birds [Columbiformes, Galliformes, Falconiformes, Passeriformes, Psittaciformes], free-ranging poultry [Anseriformes, Galliformes], bats, bovids, pigs, carnivores, rabbits [caged], hutias, and rats). Some taxonomic groups were repeated in the cases of free-ranging native and domestic birds and caged birds. However, because the way a bird is captured in the wild differs considerably from the way a caged bird is captured (i.e., little chance to evade the snake), we split them into different categories. We assumed that each of the 16 resource states involved different foraging modes, energy costs, and energy gains. We analyzed the niche breadth at two levels, for the species as a whole and separately for boas found in natural habitats and for those in anthropogenic habitats.

To test the hypothesis that the diets of boas in natural and anthropogenic habitats differ, we grouped the prey items into four classes (i.e., amphibians, reptiles, birds, and mammals) and then grouped all predation events into the two habitat categories based on qualitative criteria. We designated as natural habitats all localities without permanent evidence of human activities (Fig. 3). These are mostly karstic areas with caves and primary vegetation in the form of dense forests. Some areas with semi-natural or secondary vegetation far from permanent human settlements also were considered natural. We designated as anthropogenic habitats those localities with an ongoing incidence of human activities (Fig. 3). These are matrices of heavily disturbed habitats usually set aside for agriculture and/or stockbreeding, with isolated patches of secondary vegetation and usually located in rural, suburban, or urban areas (e.g., small villages and surroundings, farms, pastures, sugarcane fields, fruit plantations).

To test the hypothesis that an ontogenetic shift in diet occurs in Ch. angulifer, we grouped boas into four size classes: (1) Juveniles (<1.0 m SVL), (2) subadults and small adults (1.0-2.0 m SVL; sexual maturation occurs within this size range: $-1.15 \mathrm{~m} \mathrm{SVL}$ in males, $\sim 1.3 \mathrm{~m} \mathrm{SVL}$ in females; Rodríguez-Cabrera et al. 2016b), (3) medium-sized adults (>2.0-3.0 m SVL), and (4) large adults (>3.0 m SVL). Hardy (1957) did not provide the exact sizes of five snakes preying on bats; we placed them in the subadult/small adult category based on an estimated mean value derived from the range in sizes of the snakes he studied (see Appendix I). Because of the wide range of sizes and body shapes among birds and mammals, we split those prey items into several categories, resulting in 11 total categories of prey (i.e., amphibians [50-300 g], reptiles $[<100 \mathrm{~g}$ ], small birds $[<100 \mathrm{~g}]$, medium-sized birds $[100-500 \mathrm{~g}]$, large birds $[>500 \mathrm{~g}]$, bats $[<50 \mathrm{~g}]$, rats [pups and adults, 20-120 g], hutias [young and adults, 1,200-5,000 g], rabbits [kits, 50-500 g], carnivores [domestic/feral dogs and cats, 500-4,000 g], and artiodactyls [suckling pigs, goats, and sheep, 1,000-6,000 g]). We compared prey types and their frequencies in the diets of boas in the four size classes within the same habitat type and between different habitat types. Because of the unequal number of boas in the four size classes, we limited statistical analyses to those size classes (subadult/ small adult and medium-sized adult) with sufficiently large
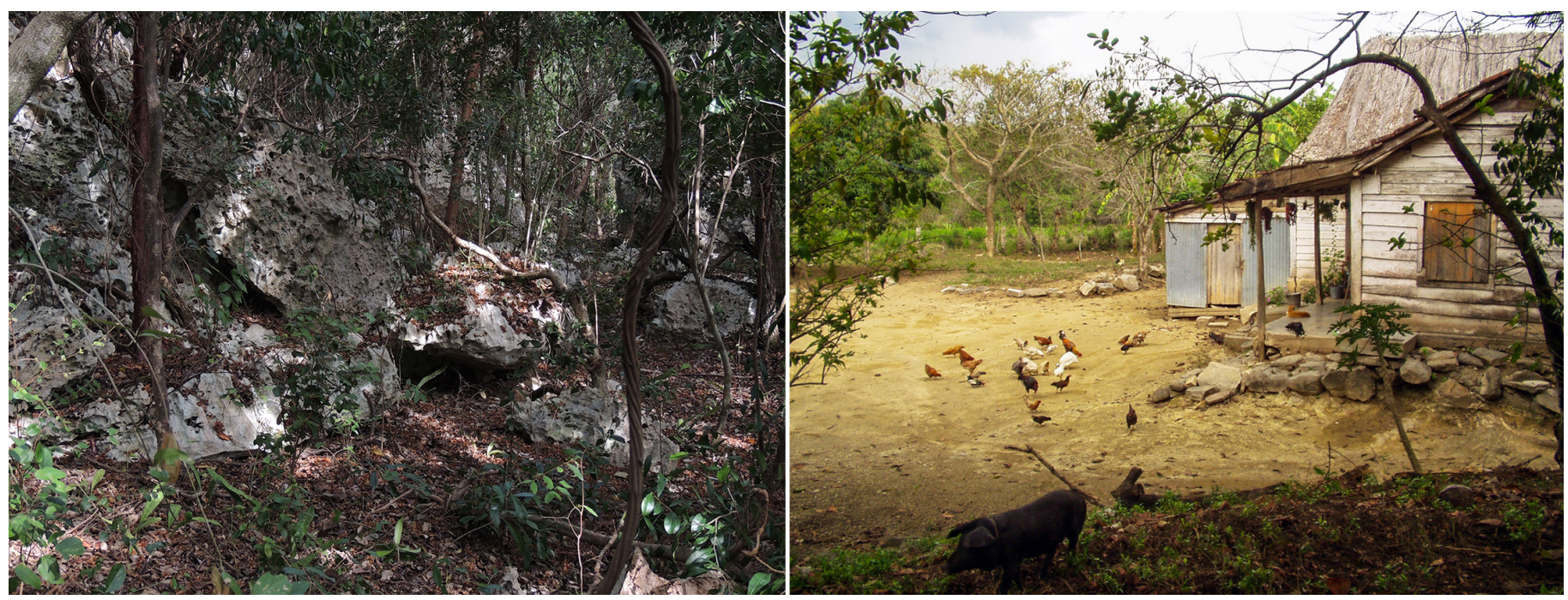

Fig. 3. Examples of habitat types where we recorded predation events by Cuban Boas (Chilabothrus angulifer): Natural habitat, semi-deciduous forest on limestone with abundance of caves on the Hicacos Peninsula, Matanzas Province (left); anthropogenic habitat, typical rustic wooden house with many domestic animals in a rural area at Cariblanca, Sancti Spíritus Province (right). Photographs @ T.M. Rodríguez-Cabrera. 
sample sizes. We used qualitative criteria to compare the other size classes. Using the R package "ggplot2" (Wickham 2016; $\mathrm{R}$ Core Team 2018), we generated a scatter plot on which we plotted the SVL of all snakes for which a measurement was available (all size classes) against prey mass. Also, to facilitate visualization and interpretation of the data, we plotted the data transformed to their cube roots (Cox 2008).

To test the hypothesis that foraging strategies of boas differed between natural and anthropogenic habitats, we used only actual predation events witnessed (i.e., snakes found while constricting or swallowing prey) to determine foraging mode and time. Although recognizing that foraging modes represent a continuum from sit-and-wait to active-foraging strategies, we classified predation events as resulting from either as sit-and-wait (ambush) or active-foraging (searching) mode (Schoener 1971). According to the time at which a predation event occurred, we classified it as diurnal or nocturnal. We also used a substantial number of stomach-content data to characterize foraging strategy. For example, we could reasonably assume which foraging strategy was used by a boa when the prey item was a domestic animal the owner was able to recognize and could provide information on its usual sleeping routine. Domestic fowl regularly use the same roosting/sleeping sites. Many of the snakes with stomach contents in anthropogenic habitats were found close to roosting sites on the next day or a few days after the prey went missing (in those cases, the assumption that an active-foraging mode was used seemed reasonable). We compared the proportion of boas using each foraging mode in natural habitats and anthropogenic habitats.

Statistical analysis.-We conducted permutational multivariate analyses of variance (PERMANOVA) to test the null hypotheses of no differences in prey composition and frequency of occurrence in the diet of Ch. angulifer between habitats and among size classes. First, we conducted a multivariate one-factor design: Factor Habitat (two levels fixed: natural and anthropogenic) to test for global differences in diet composition (amphibians, reptiles, birds, and mammals) and frequency between habitats. Second, we conducted a multivariate (11 categories) two-factor design: Factor Habitat (two levels fixed: natural and anthropogenic) and Factor Size Class (two levels fixed: subadults/small adults and mediumsized adults). We calculated Bray-Curtis similarity matrices from fourth root-transformed data and the permutation tests used 9999 unrestricted permutations of raw data for the first analysis. We also ran permutations of residuals under a reduced model for the second analysis. We used the PRIMER-E (v6.1.16) and PERMANOVA+ (v1.0.6) statistical packages (Clarke and Warwick 2001, Anderson et al. 2008) to conduct analyses. Using R software (R Core Team 2018), we conducted Pearson's chi-squared tests with Yates's continuity corrections $\left(\chi^{2}\right)$ to test the null hypotheses of: (1) independence of habitat type and foraging strategy and (2) independence of habitat type and foraging time.

\section{Results}

General diet composition and trophic niche breadth.-We recorded 351 prey items obtained from 218 snakes: 71 items from the literature $(\mathrm{n}=31$ snakes) and 280 items from this work ( $\mathrm{n}=187$ snakes; Table 1). We confirmed 49 different taxa in the diet of $C h$. angulifer. Most prey items were endotherms ( $\mathrm{n}=337$ items [96\%]; $\mathrm{n}=204$ snakes), whereas ectotherms represented only a small portion $(\mathrm{n}=14$ items [4\%]; $\mathrm{n}=14$ snakes). Mammals represented $54.7 \%$ of total prey items consumed ( $\mathrm{n}=192$ items; $\mathrm{n}=105$ snakes), followed by birds ( $\mathrm{n}=145$ items [41.3\%]; $\mathrm{n}=99$ snakes), whereas amphibians ( $\mathrm{n}=7$ items [2\%]; $\mathrm{n}=7$ snakes) and reptiles ( $\mathrm{n}$ $=7$ items $[2 \%] ; \mathrm{n}=7$ snakes) comprised only a small proportion of the diet (Table 1; Fig. 4). The prey species most frequently consumed were domestic fowl (Gallus gallus) (24.8\%), Desmarest's Hutias (Capromys pilorides) (14.5\%), two bat species (Jamaican Fruit-eating Bat [Artibeus jamaicensis]: 8.8\%; Cuban Flower Bat [Phyllonycteris poeyi]: 6.0\%), and House Rats (Rattus rattus) (7.7\%); the remaining prey species were taken only sporadically.

Our data show that $C h$. angulifer has a narrow trophic niche $\left(\mathrm{B}^{\prime}=0.319\right)$. Most snakes $(75.4 \%)$ consumed only four prey types (free-ranging poultry [32.1\%], hutias [19.9\%], bats $[11.9 \%]$, and rats $[11.5 \%])$. When we analyzed the trophic niche breadths of boas in the two habitat types, the species had a slightly wider niche in natural habitats $\left(\mathrm{B}^{\prime}=0.321\right)$ than in anthropogenic habitats $\left(\mathrm{B}^{\prime}=0.135\right)$. In natural habitats, most boas $(83.3 \%)$ consumed only four prey types (hutias [33.3\%], bats [22.8\%], rats [15.8\%], and forest birds [11.4\%]). In anthropogenic habitats, most boas (77.9\%) consumed only two prey types (free-ranging poultry [65.4\%] and caged birds [12.5\%]).

Most of the snakes with stomach contents $(n=116$ snakes) contained a single prey item $(\mathrm{n}=84$ snakes, $72.4 \%)$,

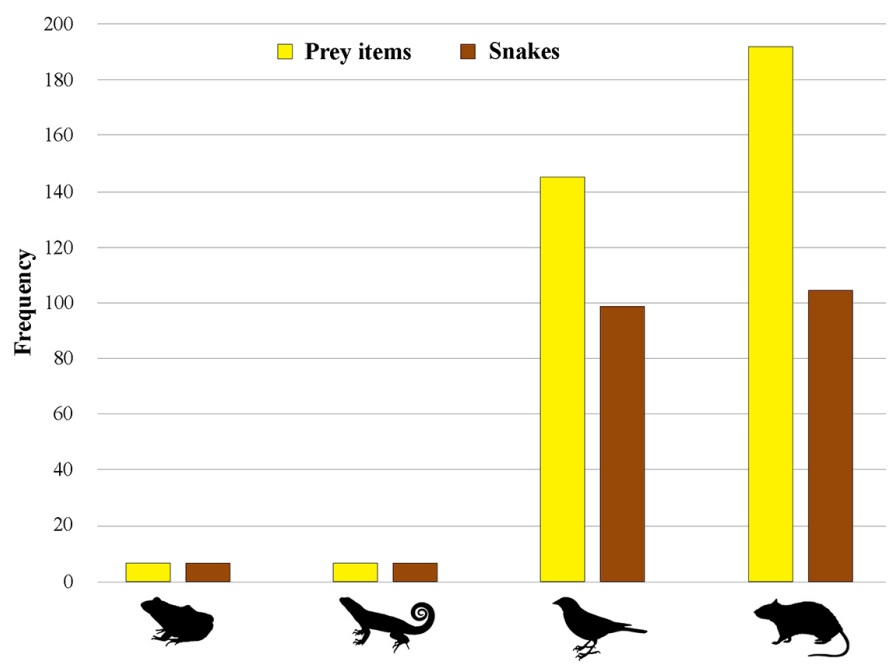

Fig. 4. Frequency of occurrence of four prey types (amphibians, reptiles, birds, and mammals) in the diet of the Cuban Boa (Chilabothrus angulifer). Columns indicate the number of prey items and the number of snakes found consuming each resource. 
Table 1. Prey taxa confirmed for free-ranging Cuban Boas (Chilabothrus angulifer) in natural (NAT) and anthropogenic (ANT) habitats, including data from the literature and this work. The percentage of total prey items represented by each species is listed in parentheses after the name of the species. The number of prey items is followed (in parenthesis) by the number of snakes involved; question marks (?) represent unknown data. Prey growth states (GS) were defined as adult (A), juvenile/nestling/hatchling (J), and egg (E). Snake size classes are juveniles (JU: $<1.0 \mathrm{~m} \mathrm{TL}$ ), subadults/small adults (SA: 1.0-2.0 m TL), mediumsized adults (MA: > 2.0-3.0 m TL), and large adults (LA: > 3.0 m TL). When a prey species is reported by one or more authors, a superscript indicates the number of items referred. Sources: 1. This paper; 2. Tolson (2012); 3. Holanova and Hribal (2004), V. Holanova, in litt. 6.iv.2020; 4. Viña and Armas (1988); 5. Sampedro and Montañez (1989); 6. Sampedro (1998, in litt. 6.xii.2015; 7. Vázquez and Nieves (1980); 8. Godínez et al. (1987); 9. Segovia et al. (2013); 10. Mancina and Llanes (1997), C.A. Mancina, pers. comm. 19.v.2020; 11. Buide (1966); 12. Dinets (2017); 13. Mancina (2011), pers. comm. 19.v.2020; 14. Sheplan and Schwartz (1974); 15. Rodríguez-Cabrera et al. (2015); 16. Hardy (1957); 17. Hernández and Pimentel (2005); 18. Tolson and Petersen (2008), P.J. Tolson, in litt. 28.iii.2020; 19. Borroto-Páez (2011a); 20. Tolson and Henderson (1993), P.J. Tolson, in litt. 8.v.2020.

${ }^{a}$ Recorded as possibly Anolis bartschi (which certainly represents a different species than A. smallwoodi; see Appendix I). ${ }^{\circ}$ Recorded as Pseudemys decussata. ${ }^{c}$ Recorded as Columba leucocephala. ${ }^{\mathrm{d}}$ Recorded as Hirundo fulva.

*The six bats (i.e., "two Mormoops blainvillei, two Phyllonycteris poeyi, one Brachyphylla nana, and one small unidentifiable bat") reported by Sheplan and Schwartz (1974), were in a single snake.

\begin{tabular}{|c|c|c|c|c|c|}
\hline Prey & \multicolumn{2}{|c|}{ Prey items (Snakes) } & $\begin{array}{c}\text { Prey } \\
\text { GS }\end{array}$ & $\begin{array}{c}\text { Snake Size } \\
\text { Class }\end{array}$ & Source \\
\hline \multicolumn{6}{|l|}{ AMPHIBIA } \\
\hline \multicolumn{6}{|l|}{ Anura: Hylidae } \\
\hline Cuban Treefrog, Osteopilus septentrionalis (1.4\%) & $5(5)$ & - & A & JU, SA & 1 \\
\hline \multicolumn{6}{|l|}{ Anura: Ranidae } \\
\hline American Bullfrog, Lithobates catesbeianus (0.3\%) & - & $1(1)$ & A & SA & 1 \\
\hline \multicolumn{6}{|l|}{ REPTILIA } \\
\hline \multicolumn{6}{|l|}{ Squamata: Dactyloidae } \\
\hline Green-blotched Giant Anole, Anolis smallwoodi (0.3\%) & $1(1)$ & - & A & JU & 2 \\
\hline Unidentified anole, Anolis sp. ${ }^{a}(0.3 \%)$ & $1(1)$ & - & $?$ & JU & 3 \\
\hline \multicolumn{6}{|l|}{ Squamata: Leiocephalidae } \\
\hline \multicolumn{6}{|l|}{ Squamata: Tropidophiidae } \\
\hline Giant Trope, Tropidophis melanurus (0.3\%) & $1(1)$ & - & $\mathrm{J}$ & SA & 4 \\
\hline \multicolumn{6}{|l|}{ Testudines: Emydidae } \\
\hline Cuban Slider, Trachemys decussata ${ }^{\mathrm{b}}(0.3 \%)$ & $1(1)$ & - & $\mathrm{J}$ & SA & 5,6 \\
\hline \multicolumn{6}{|l|}{ AVES } \\
\hline \multicolumn{6}{|l|}{ Accipitriformes: Accipitridae } \\
\hline Red-tailed Hawk, Buteo jamaicensis (0.3\%) & $1(1)$ & - & A & MA & 1 \\
\hline \multicolumn{6}{|l|}{ Cathartiformes: Cathartidae } \\
\hline Turkey Vulture, Cathartes aura $(0.6 \%)$ & $2(1)$ & - & $\mathrm{J}$ & MA & 1 \\
\hline \multicolumn{6}{|l|}{ Anseriformes: Anatidae } \\
\hline \multicolumn{6}{|l|}{ Cuculiformes: Cuculidae } \\
\hline Great Lizard-Cuckoo, Coccyzus merlini (0.3\%) & $1(1)$ & - & A & MA & 1 \\
\hline \multicolumn{6}{|l|}{ Falconiformes: Falconidae } \\
\hline Northern Crested Caracara, Caracara cheriway (0.3\%) (caged) & - & $1(1)$ & A & MA & 1 \\
\hline \multicolumn{6}{|l|}{ Galliformes: Phasianidae } \\
\hline Japanese Quail, Coturnix japonica (2.6\%) (caged) & - & $9(1)$ & A & MA & 1 \\
\hline Domestic Chicken, Gallus gallus (24.8\%) (10 caged) & $2(2)$ & $85(61)$ & 53J, 34A & SA, MA, LA & 1 \\
\hline Wild Turkey, Meleagris gallopavo (1.1\%) & - & $4(2)$ & $\mathrm{J}$ & SA & 1 \\
\hline
\end{tabular}




\begin{tabular}{|c|c|c|c|c|c|}
\hline \multirow[b]{2}{*}{ Prey } & \multicolumn{2}{|c|}{ Prey items (Snakes) } & \multirow{2}{*}{$\begin{array}{c}\text { Prey } \\
\text { GS }\end{array}$} & \multirow{2}{*}{$\begin{array}{l}\text { Snake Size } \\
\text { Class }\end{array}$} & \multirow[b]{2}{*}{ Source } \\
\hline & NAT & ANT & & & \\
\hline \multicolumn{6}{|l|}{ Galliformes: Numididae } \\
\hline Helmeted Guineafowl, Numida meleagris (2.0\%) & - & $7(6)$ & $6 \mathrm{~J}, 1 \mathrm{~A}$ & SA & 1 \\
\hline \multicolumn{6}{|l|}{ Gruiformes: Rallidae } \\
\hline Purple Gallinule, Porphyrio martinicus (0.3\%) & $1(1)$ & - & A & SA & 1 \\
\hline \multicolumn{6}{|l|}{ Passeriformes: Icteridae } \\
\hline Greater Antillean Grackle, Quiscalus niger (0.3\%) & $1(1)$ & - & A & $\mathrm{JU}$ & 1 \\
\hline Unidentifed blackbird $(0.3 \%)$ & $1(1)$ & - & A? & SA & 1 \\
\hline \multicolumn{6}{|l|}{ Passeriformes: Tyrannidae } \\
\hline Gray Kingbird, Tyrannus dominicensis (0.3\%) & $1(1)$ & - & $\mathrm{J}$ & SA & 9 \\
\hline \multicolumn{6}{|l|}{ Passeriformes: Estrildidae } \\
\hline Tricolored Munia, Lonchura malacca (1.7\%) (caged) & - & $6(1)$ & A & $\mathrm{JU}$ & 1 \\
\hline \multicolumn{6}{|l|}{ Passeriformes: Hirundinidae } \\
\hline Cave Swallow, Petrochelidon fulva ${ }^{\mathrm{d}}(0.6 \%)$ & $2(1)$ & - & E & SA & 10 \\
\hline \multicolumn{6}{|l|}{ Passeriformes: Thraupidae } \\
\hline Western Spindalis, Spindalis zena (0.3\%) (caged) & - & $1(1)$ & A & $\mathrm{JU}$ & 1 \\
\hline \multicolumn{6}{|l|}{ Passeriformes: Turdidae } \\
\hline Red-legged Thrush, Turdus plumbeus (0.6\%) & $2(2)$ & - & A & SA & 1 \\
\hline \multicolumn{6}{|l|}{ Psittaciformes: Psittacidae } \\
\hline Rosy-faced Lovebird, Agapornis roseicollis (0.3\%) (caged) & - & $1(1)$ & A & JU & 1 \\
\hline Budgerigar, Melopsittacus undulatus (0.3\%) (caged) & - & $1(1)$ & A & $\mathrm{JU}$ & 1 \\
\hline Cuban Parakeet, Psittacara euops (0.3\%) (caged) & - & $1(1)$ & A & $\mathrm{JU}$ & 1 \\
\hline \multicolumn{6}{|l|}{ MAMMALIA } \\
\hline \multicolumn{6}{|l|}{ Artiodactyla: Bovidae } \\
\hline Domestic Goat, Capra hircus (0.6\%) & - & $2(2)$ & $\mathrm{J}$ & LA & $11^{1}, 1^{1}$ \\
\hline Domestic Sheep, Ovis aries $(0.3 \%)$ & - & $1(1)$ & $\mathrm{J}$ & LA & 1 \\
\hline \multicolumn{6}{|l|}{ Artiodactyla: Suidae } \\
\hline Domestic Pig, Sus scrofa (3.7\%) & $5(1)$ & $8(3)$ & $\mathrm{J}$ & MA, LA & 1 \\
\hline \multicolumn{6}{|l|}{ Carnivora: Canidae } \\
\hline Domestic Dog, Canis lupus familiaris (1.1\%) & - & $4(2)$ & $\mathrm{J}$ & SA & 1 \\
\hline \multicolumn{6}{|l|}{ Carnivora: Felidae } \\
\hline Domestic Cat, Felis catus (1.1\%) & $1(1)$ & $3(3)$ & $2 \mathrm{~J}, 2 \mathrm{~A}$ & SA, MA & 1 \\
\hline Chiroptera: Phyllostomidae & & & & & \\
\hline Jamaican Fruit-eating Bat, Artibeus jamaicensis (8.8\%) & $31(9)$ & - & A & SA & 12 \\
\hline Cuban Fruit-eating Bat, Brachyphylla nana* $(0.6 \%)$ & $2(2)$ & - & A & SA & $13^{1}, 14^{1}$ \\
\hline Buffy Flower Bat, Erophylla sezekorni (1.7\%) & $6(3)$ & - & $3 \mathrm{~J}, 3 \mathrm{~A}$ & JU, SA & $15^{3}, 1^{3}$ \\
\hline Cuban Flower Bat, Phyllonycteris poeyi ${ }^{*}(6.0 \%)$ & $21(10)$ & - & A & JU, SA & $1^{1}, 14^{2}, 15^{3}, 16^{15}$ \\
\hline Chiroptera: Mormoopidae & & & & & \\
\hline Antillean Ghost-faced Bat, Mormoops blainvillei* $(1.1 \%)$ & $4(2)$ & - & A & SA & $14^{2}, 1^{2}$ \\
\hline Unidentified bats $^{*}(1.7 \%)$ & $6(3)$ & - & A? & SA & $14^{1}, 1^{5}$ \\
\hline Lagomorpha: Leporidae & & & & & \\
\hline European Rabbit, Oryctolagus cuniculus (4.3\%) (caged) & - & $15(2)$ & $\mathrm{J}$ & SA, MA & 1 \\
\hline Rodentia: Capromyidae & & & & & \\
\hline Desmarest's Hutia, Capromys pilorides (14.5\%) & $51(37)$ & - & $8 \mathrm{~J}, 43 \mathrm{~A}$ & SA, MA, LA & $17^{1}, 18^{1}, 1^{49}$ \\
\hline Prehensile-tailed Hutia, Mysateles prehensilis (0.3\%) & - & $1(1)$ & A & MA & 1 \\
\hline Black-tailed Hutia, Mesocapromys melanurus (0.3\%) & $1(1)$ & - & A & MA & 1 \\
\hline Rodentia: Muridae & & & & & \\
\hline House Rat, Rattus rattus (7.7\%) & $22(17)$ & $5(5)$ & $5 \mathrm{~J}, 22 \mathrm{~A}$ & SA, MA, LA & $19^{1}, 20^{1}, 1^{25}$ \\
\hline Brown Rat, Rattus norvegicus (0.3\%) & - & $1(1)$ & A & MA & 1 \\
\hline Unidentified rats, Rattus sp. (0.6\%) & $1(1)$ & $1(1)$ & A & MA & 1 \\
\hline Total prey items (351) & 184 & 167 & & & \\
\hline Total snakes (218) & 114 & 104 & & & \\
\hline Total prey species (49) & 29 & 24 & & $s$ in both habit & t types \\
\hline
\end{tabular}


but 32 snakes (27.6\%) contained two or more items (Table 2). Thus, for several prey species, the number of items recorded was higher than the number of snakes containing them (Fig. 4; Table 1). The maximum number of prey items in a single boa was nine ( $\mathrm{n}=3$ snakes; Table 2 ). In a single instance, a snake contained more than one prey species in its stomach (all bats; $\mathrm{n}=6$ items) (Tables 1 and 2, Appendix I). One snake (1.47 $\mathrm{m}$ SVL) was observed swallowing an adult Buffy Flower Bat (Erophylla sezekorni) while constricting another bat of the same species. Another snake ( $<2.0 \mathrm{~m} \mathrm{SVL})$ was observed coiled in the nest of a Cave Swallow (Petrochelidon fulva) a short time after the nest had been checked and had contained two eggs (Appendix I). These two cases represent the only snakes found in the act of predation involving multiple prey items in natural habitats. Seven snakes in anthropogenic habitats contained prey items in their stomach while constricting or swallowing other individuals of the same species ( $\mathrm{n}=37$ items).

Ninety-five snakes (43.6\%) were observed while taking prey (Table 3$)$. Half $(\mathrm{n}=47$ snakes, $49.5 \%)$ were preying on poultry, $16(16.8 \%)$ on bats, and ten $(10.5 \%)$ on ectotherms. Fewer snakes were observed preying on hutias $(n=8,8.4 \%)$, rats $(n=6,6.3 \%)$, forest birds $(n=6,6.3 \%)$, and other prey types.

Diets in natural and anthropogenic habitats. - We identified 29 taxa in natural habitats $(\mathrm{n}=184$ items; $\mathrm{n}=114$ snakes) and 24 taxa in anthropogenic habitats ( $\mathrm{n}=167$ items; $\mathrm{n}=104$ snakes) (Table 1). We found significant differences in the dietary composition of boas in natural and anthropogenic habitats (pseudo- $\mathrm{F}_{(1)}=90.477 ; \mathrm{P}=0.0001$; Table 4A).

Only four prey taxa (rats [Rattus rattus], domestic fowl [Gallus gallus], cats [Felis catus], and pigs [Sus scrofa]) were consumed by snakes in both habitat types, albeit in different proportions (Table 1). Mammals were consumed more frequently in natural habitats $(82.1 \%, \mathrm{n}=151$ items; $\mathrm{n}=84$ snakes) than in anthropogenic habitats $(24.6 \%, \mathrm{n}=41$ items; $\mathrm{n}=21$ snakes) (Fig. 5). The most frequently taken prey items in natural habitats were bats ( $\mathrm{n}=70$ items [38\%]; $\mathrm{n}=26$ snakes), followed by hutias (Capromys and Mesocapromys, $\mathrm{n}$ $=52$ items [28.3\%]; $\mathrm{n}=38$ snakes), and rats (Rattus; $\mathrm{n}=23$ items [12.5\%]; $\mathrm{n}=18$ snakes) (Fig. 6). Domestic animals consumed in natural habitats were feral (i.e., cats) or semiferal (i.e., chickens and pigs) and represented only a small portion of the total number of prey items consumed ( $\mathrm{n}=$ 8 items [4.4\%]; $\mathrm{n}=4$ snakes). Birds were more frequently consumed by boas in anthropogenic habitats ( $\mathrm{n}=124$ items [74.3\%]; $\mathrm{n}=81$ snakes) than by boas in natural habitats $(\mathrm{n}=$ 21 items [11.4\%]; $\mathrm{n}=18$ snakes). The most frequently taken prey items in anthropogenic habitats were domestic chickens ( $\mathrm{n}=85$ items; $\mathrm{n}=61$ snakes), which comprised $50.9 \%$ of all prey items and $68.6 \%$ of all birds consumed in this habitat type. All native or introduced feral birds (i.e., Caracaras [Caracara cheriway], Quail Doves [Geotrygon montana], Munias [Lonchura malacca], Parakeets [Psittacara euops], and Spindalis [Spindalis zena]) consumed in anthropogenic habitats ( $\mathrm{n}=10$ items, $\mathrm{n}=5$ snakes) were caged. Rats accounted for only $4.2 \%$ of the total number of prey items taken in anthropogenic habitats ( $\mathrm{n}=7$ items; $\mathrm{n}=7$ snakes; Fig. 7 ). Artiodactyls ( $\mathrm{n}=16$ items) were consumed only by snakes larger than $2.5 \mathrm{~m}$ SVL ( $\mathrm{n}=3$ medium-sized adults; $\mathrm{n}=4$ large adults; Fig. 6). Except for one snake (>3.0 m SVL) in a natural habitat that contained five suckling semi-feral pigs, all artiodactyl prey were taken by boas in anthropogenic habitats. The largest measured snake included in this work was an adult female $5.65 \mathrm{~m}$ in total length (ca. $5.0 \mathrm{~m} \mathrm{SVL}$ ) and probably exceeding $40 \mathrm{~kg}$ that had been killed on a farm near the village of Las Vegas, Guamuhaya Massif, Cuamayagua,

Table 2. Individual Cuban Boas (Chilabothrus angulifer) with multiple prey items determined either by examination of stomach contents and/or observations of predation events. References (superscripts): 1. Mancina and Llanes (1997); C.A. Mancina, pers. comm. 19.v.2020; 2. Rodríguez-Cabrera et al. (2015); 3. Hardy (1957); 4. Sheplan and Schwartz (1974).

\begin{tabular}{|c|c|c|}
\hline Items & Snakes & Prey species (number of prey items and growth states) \\
\hline 2 & 17 & $\begin{array}{l}\text { Turkey Vultures, Cathartes aura ( } 2 \text { chicks), Rock Pigeons, Columba livia ( } 2 \text { adults), Wild Turkeys, Meleagris } \\
\text { gallopavo ( } 2 \text { chicks), Helmeted Guineafowl, Numida meleagris ( } 2 \text { chicks), Cave Swallows, Petrochelidon fulva } \\
\text { ( } 2 \text { eggs) })^{1} \text {, Mourning Doves, Zenaida macroura ( } 2 \text { adults), Buffy Flower Bats, Erophylla sezekorni ( } 2 \text { adults), } \\
\text { Desmarest's Hutias, Capromys pilorides ( } 2 \text { young and } 14 \text { adults), Antillean Ghost-faced Bats, Mormoops blainvil- } \\
\text { lei ( } 2 \text { adults), Domestic Pigs, Sus scrofa ( } 2 \text { sucklings) }\end{array}$ \\
\hline 3 & 9 & $\begin{array}{l}\text { Muscovy Ducks, Cairina moschata (chicks), Domestic Dogs, Canis lupus familiaris ( } 3 \text { sucklings), Buffy Flower } \\
\text { Bats, Erophylla sezekorni ( } 3 \text { sucklings) }{ }^{2} \text {, Desmarest's Hutias, Capromys pilorides ( } 9 \text { adults), Cuban Flower Bats, } \\
\text { Phyllonycteris poeyi ( } 3 \text { adults) }{ }^{3} \text {, Domestic Pigs, Sus scrofa ( } 6 \text { sucklings) }\end{array}$ \\
\hline 4 & 1 & Unidentified bats \\
\hline 5 & 1 & Domestic Pigs, Sus scrofa (sucklings) \\
\hline 6 & 3 & $\begin{array}{l}\text { Bats spp. (1 Cuban Fruit-eating Bat, Brachyphylla nana; } 2 \text { Antillean Ghost-faced Bats, Mormoops blainvillei; } 2 \\
\text { Cuban Flower Bats, Phyllonycteris poeyi; } 1 \text { unidentified bat })^{4} \text {; European Rabbits, Oryctolagus cuniculus (6 suck- } \\
\text { lings); House Rats, Rattus rattus (5 sucklings and } 1 \text { adult female) }\end{array}$ \\
\hline 9 & 3 & $\begin{array}{l}\text { Japanese Quail, Coturnix japonica (9 adults); Domestic Chickens, Gallus gallus (8 chicks and } 1 \text { hen); Cuban } \\
\text { Flower Bats, Phyllonycteris poeyi ( } 9 \text { adults) }\end{array}$ \\
\hline
\end{tabular}


Table 3. Observations of predation events by Cuban Boas (Chilabothrus angulifer) in natural (NAT) and anthropogenic (ANT) habitats. Asterisks $\left({ }^{*}\right)$ indicate that more prey items than those observed being taken were revealed later as stomach contents (e.g., four snakes preying on Domestic Chickens [Gallus gallus]). When a prey species has been reported by one or more authors, a superscript indicates the number of snakes involved. References: 1. This paper; 2. Holanova and Hribal (2004), V. Holanova, in litt. 6.iv.2020; 3. Viña and Armas (1988); 4. Sampedro and Montañez (1989); 5. Sampedro (1998), in litt. 6.xii.2015; 6. Segovia et al. (2013); 7. Mancina and Llanes (1997), C.A. Mancina, pers. comm. 19.v.2020; 8. Dinets (2017); 9. Mancina (2011), pers. comm. 19.v.2020; 10. Rodríguez-Cabrera et al. (2015); 11. Hardy (1957); 12. Tolson and Petersen (2008), P.J. Tolson, in litt. 28.iii.2020; 13. BorrotoPáez (2011a); 14. Tolson and Henderson (1993), P.J. Tolson, in litt. 8.v.2020.

\begin{tabular}{lccccc} 
Prey & Items & Snakes & Time & Habitat & Source \\
\hline Cuban Treefrog, Osteopilus septentrionalis & 5 & 5 & day & NAT & 1 \\
\hline Western Cuba Giant Toad, Peltophryne fustiger & 1 & 1 & night & NAT & 1 \\
\hline Unidentified anole, Anolis sp. & 1 & 1 & night & NAT & 2 \\
\hline Cuban Iguana, Cyclura nubila & 1 & 1 & day & ANT & 1 \\
\hline Giant Trope, Tropidophis melanurus & 1 & 1 & day & NAT & 3 \\
\hline Cuban Slider, Trachemys decussata & 1 & 1 & night & NAT & 4,5 \\
\hline Rock Pigeon, Columba livia (caged) & 1 & 1 & night & ANT & 1 \\
\hline Zenaida Dove, Zenaida aurita & 1 & 1 & day & NAT & 1 \\
\hline Domestic Chicken, Gallus gallus (2 snakes on caged birds) & $45^{*}$ & 45 & day', night ${ }^{44}$ & ANT & 1 \\
\hline Wild Turkey, Meleagris gallopavo & $1^{*}$ & 1 & night & ANT & 1 \\
\hline Helmeted Guineafowl, Numida meleagris & 5 & 5 & night & ANT & 1 \\
\hline Greater Antillean Grackle, Quiscalus niger & 1 & 1 & day & NAT & 1 \\
\hline Gray Kingbird, Tyrannus dominicensis & 1 & 1 & night & NAT & 6 \\
\hline Tricolored Munia, Lonchura malacca (caged) & $1^{*}$ & 1 & night & ANT & 1 \\
\hline Cave Swallow, Petrochelidon fulva (eggs) & 2 & 1 & day & NAT & 7 \\
\hline Red-legged Thrush, Turdus plumbeus & 1 & 1 & day & NAT & 1 \\
\hline Great Lizard-Cuckoo, Coccyzus merlini & 1 & 1 & day & NAT & 1 \\
\hline Rosy-faced Lovebird, Agapornis roseicollis (caged) & 1 & 1 & night & ANT & 1 \\
\hline Domestic Cat, Felis catus & 1 & 1 & day & NAT & 1 \\
\hline Jamaican Fruit-eating Bat, Artibeus jamaicensis & 31 & 9 & night & NAT & 8 \\
\hline Cuban Fruit-eating Bat, Brachyphylla nana & 1 & 1 & day & NAT & 9 \\
\hline Buffy Flower Bat, Erophylla sezekorni & 2 & 1 & night & NAT & 1 \\
\hline Cuban Flower Bat, Phyllonycteris poeyi & 4 & 4 & night & NAT & $10^{1}, 11^{3}$ \\
\hline Unidentified bat & 1 & 1 & day & NAT & 1 \\
\hline European Rabbit, Oryctolagus cuniculus (caged) & $1 *$ & 1 & night & ANT & 1 \\
\hline Desmarest's Hutia, Capromys pilorides & 6 & 8 & day & NAT & $12^{1}, 1^{7}$ \\
\hline House Rat, Rattus rattus & & day & NAT ${ }^{5}$, ANT & $13^{1}, 14^{1}, 1^{4}$ \\
\hline
\end{tabular}

Table 4. Permutational multivariate analyses of variance (PERMANOVA) on the dietary composition of Cuban Boas (Chilabothrus angulifer) in natural and anthropogenic habitats (A) and among size classes (B): subadults/ small adults in natural and anthropogenic habitats, and medium-sized adults in natural and anthropogenic habitats. All values are significant at $\alpha=0.05 . \mathrm{df}=$ degrees of freedom, MS = mean squares.

\begin{tabular}{lccccc} 
Source of Variation & df & MS & Pseudo-F & P (perm) \\
\hline A & Habitat & 1 & 48581 & 90.477 & 0.0001 \\
\hline & Residual & 225 & 536.95 & & \\
\hline & & & & \\
\hline B $\quad$ Habitat & 1 & 17998 & 19.778 & 0.0001 \\
\hline & Size class & 1 & 14573 & 16.014 & 0.0001 \\
\hline & Habitat x Size Class & 1 & 8114.1 & 8.9164 & 0.0001 \\
\hline & 171 & 910.01 & & \\
\hline
\end{tabular}

Cienfuegos Province in 1987; it contained a young domestic goat (Capra hircus) ca. $6.0 \mathrm{~kg}$ (J.D. León, pers. comm. 2012).

Desmarest's Hutia was the most frequent prey species consumed in natural habitats $(\mathrm{n}=51$ items $[27.7 \%] ; \mathrm{n}=37$ snakes; Fig. 8). Only one boa ( $>2.0 \mathrm{~m} \mathrm{SVL}$ ) in a natural habitat near Farallones, Moa, Holguín Province, contained an adult Black-tailed Hutia (Mesocapromys melanurus) (G. Begué, pers. comm. 2013; Fig. 9). Another boa (ca. $3.0 \mathrm{~m} \mathrm{SVL)} \mathrm{found} \mathrm{in}$ a secondary grove associated with an anthropogenic habitat at Cariblanca in Sancti Spíritus Province contained an adult Prehensile-tailed Hutia (Mysateles prehensilis), the only case of predation on hutias in this type of habitat. Snakes $(\mathrm{n}=31)$ containing hutias (Capromys, Mesocapromys, and Mysateles) in their stomachs belonged to all size classes except juveniles, and the number of items per stomach varied: one item $(\mathrm{n}=$ 


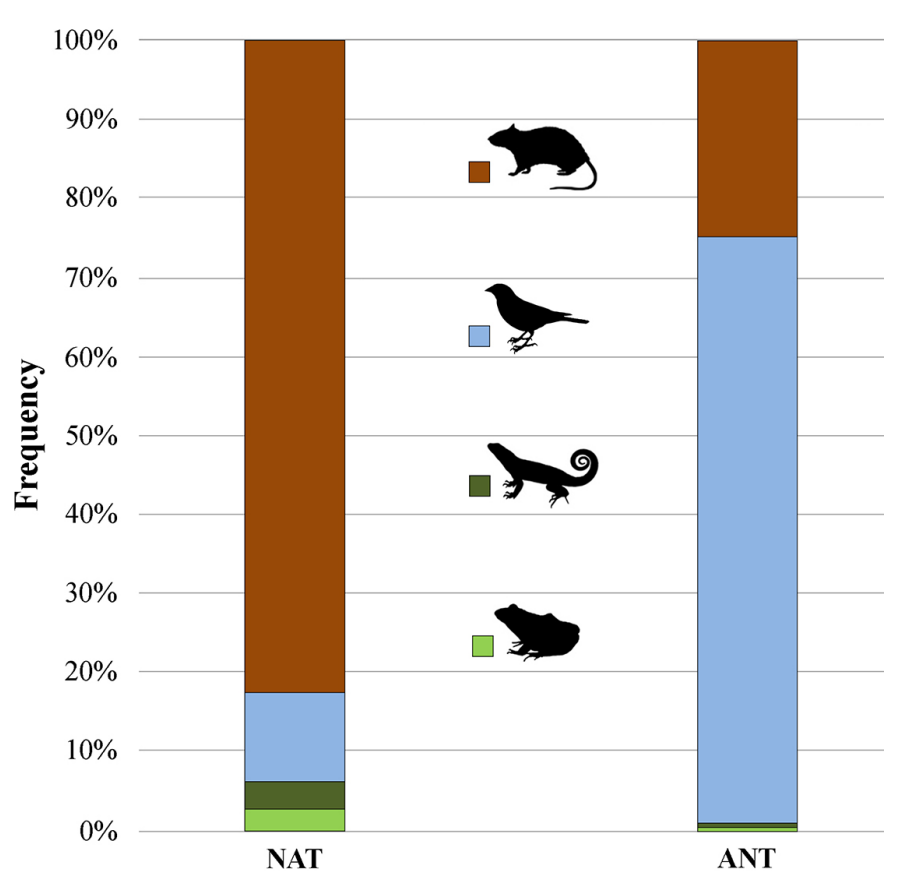

Fig. 5. Frequency of occurrence (number of prey items) of four prey types (amphibians, reptiles, birds, and mammals) in the diet of Cuban Boas (Chilabothrus angulifer) in natural (NAT) and anthropogenic habitats (ANT).
2 subadults/small adults; $\mathrm{n}=10$ medium-sized adults; $\mathrm{n}=$ 8 large adults), two items ( $\mathrm{n}=2$ medium-sized adults; $\mathrm{n}=$ 6 large adults), and three items $(\mathrm{n}=3$ large adults) (Table 2). Most of the snakes that preyed on Ca. pilorides ( $\mathrm{n}=37$ snakes: 29 stomach contents and 8 found preying) exceeded $2.0 \mathrm{~m} \mathrm{SVL}$, with the exception of only four subadults/small adults ( 2 encountered during a predation event and 2 stomach contents) ranging in size from $1.7-1.8 \mathrm{~m}$ in total length (ca. 1.5-1.6 m SVL), each of which had taken a juvenile hutia (ca. $2.0 \mathrm{~kg}$ each). Mourning Doves (Zenaida macroura) were repeatedly reported as prey of subadult/small adult snakes in natural habitats ( $\mathrm{n}=6$ items; $\mathrm{n}=5$ snakes; Fig. 10). Two snakes ( $>2.5 \mathrm{~m} \mathrm{SVL}$ ) in natural habitats contained a partially digested adult Red-tailed Hawk (Buteo jamaicensis) and two large nestling Turkey Vultures (Cathartes aura), respectively (Table 1). Ectotherms, including anurans (Cuban Treefrogs, Osteopilus septentrionalis, American Bullfrogs, Lithobates catesbeianus, and Western Cuba Giant Toads, Peltophryne fustiger, $\mathrm{n}=7$ items), lizards (anoles, Anolis spp.; Cuban Iguana, Cyclura nubila; Saw-scaled Curlytail, Leiocephalus carinatus; $\mathrm{n}=5$ items), a Giant Trope (Tropidophis melanurus, $\mathrm{n}=1$ item), and a hatchling Cuban Slider (Trachemys decussata; $\mathrm{n}=$

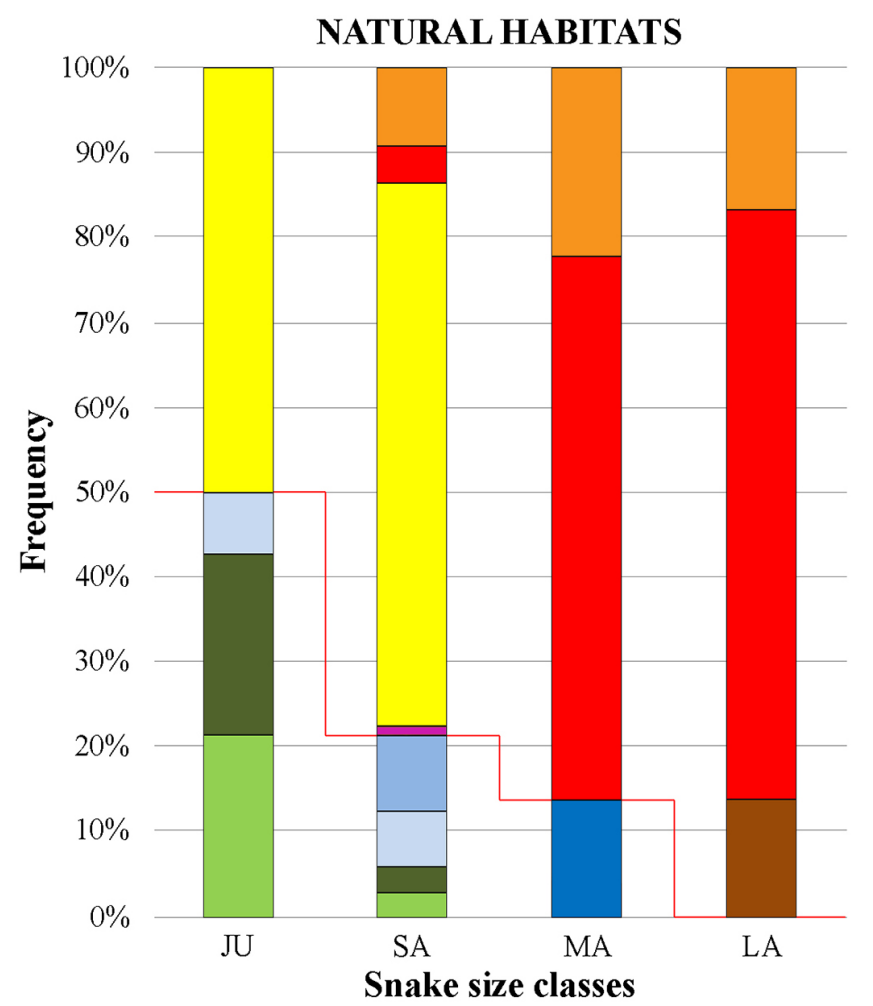

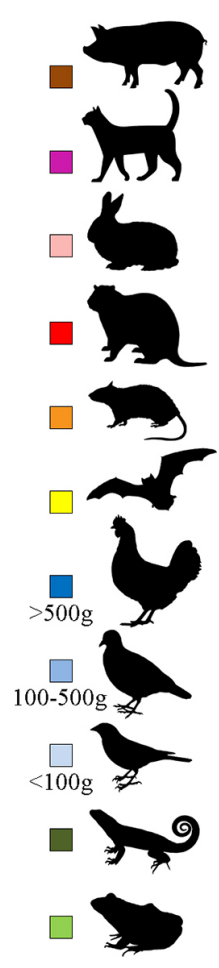

Snake size classes

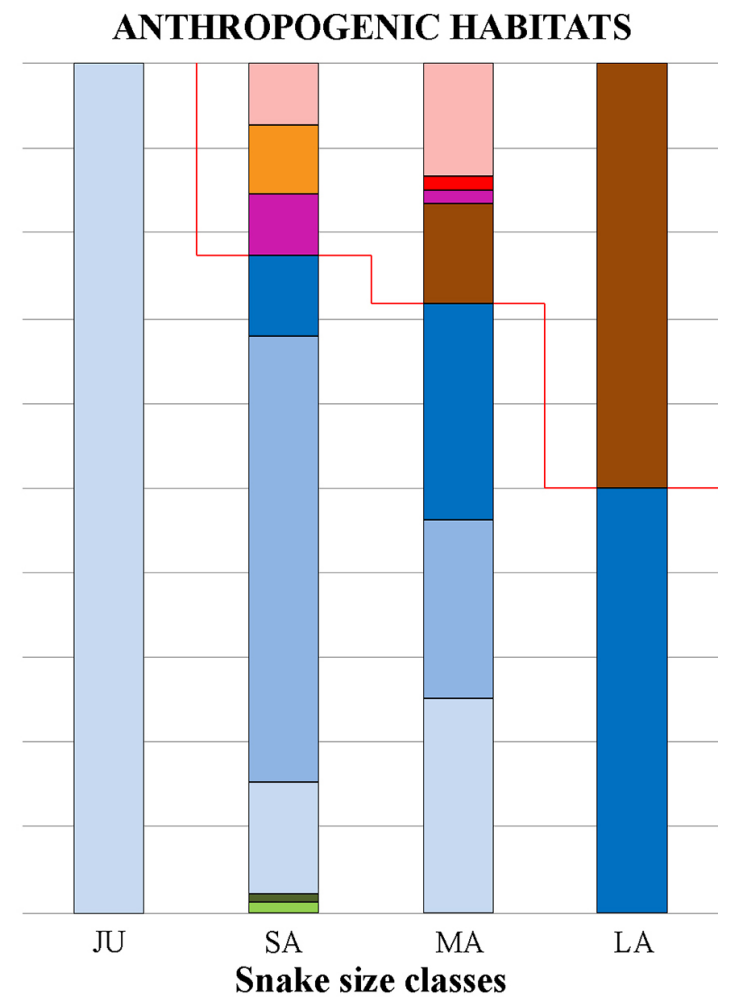

Fig. 6. Frequency of occurrence (number of prey items) of 11 prey types in the diet of Cuban Boas (Chilabothrus angulifer) found in two different habitat types. Snake size classes are juveniles (JU), subadults/small adults (SA), medium-sized adults (MA), and large adults (LA). Prey types in the legend are (from below to above): amphibians, reptiles, small birds, medium-sized birds, large birds, bats, rats, hutias, rabbits, carnivores, and artiodactyls. Mammals are above the red line. 


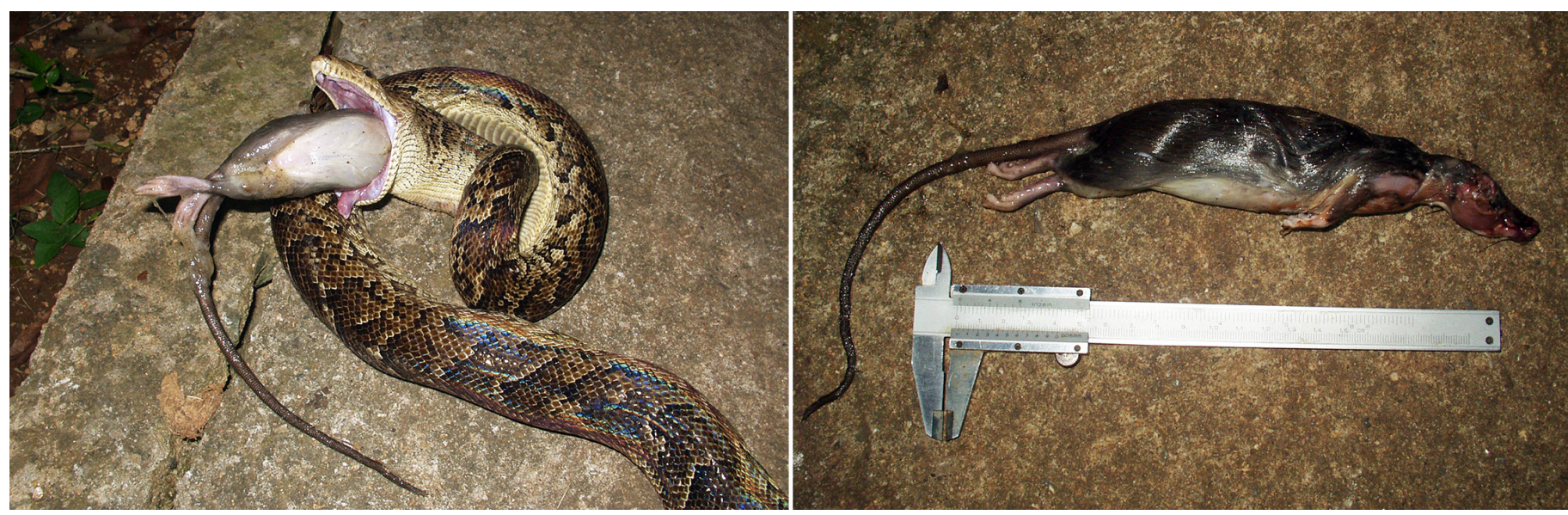

Fig. 7. A small adult Cuban Boa (Chilabothrus angulifer) (1.5 m SVL) containing an adult House Rat (Rattus rattus) (ca. $120 \mathrm{~g}$ ) in an anthropogenic habitat in the Cienfuegos Botanical Garden, Cienfuegos Province. Photographs (C) T.M. Rodríguez-Cabrera.
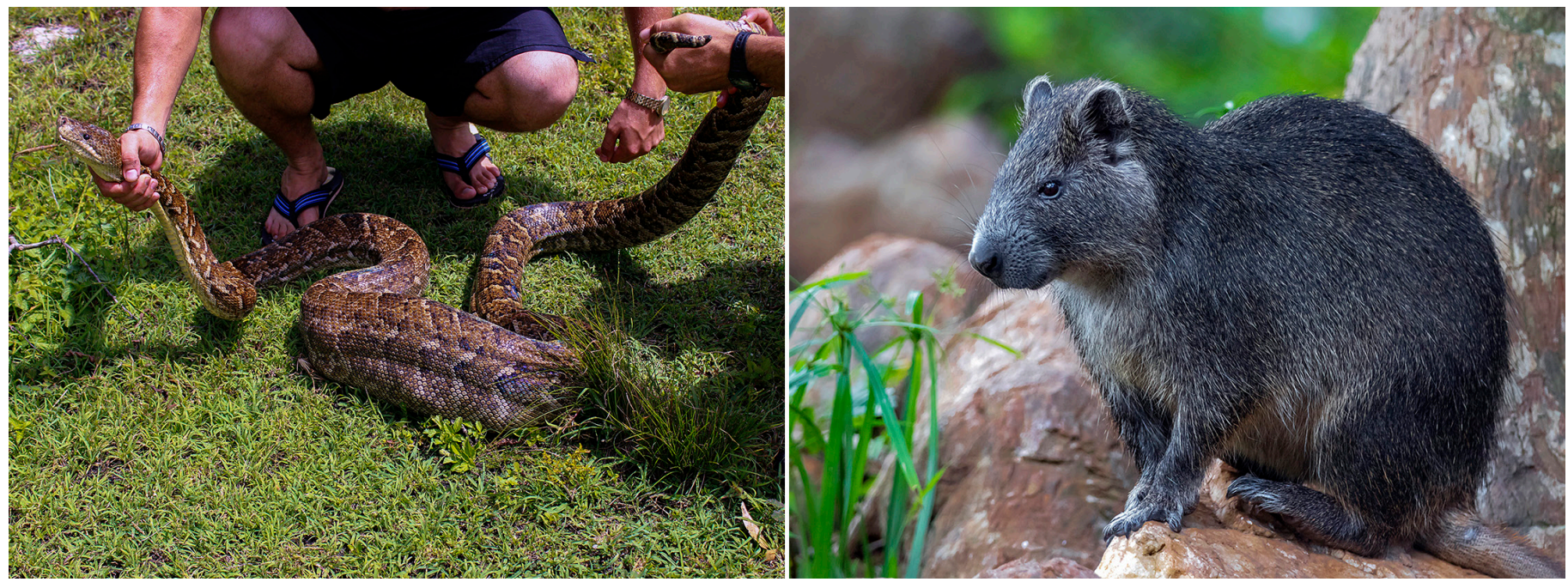

Fig. 8. A medium-sized Cuban Boa (Chilabothrus angulifer) (ca. $3.0 \mathrm{~m} \mathrm{SVL}$ ) containing a Desmarest's Hutia (Capromys pilorides) in a natural habitat in the Zapata Swamp, Matanzas Province (left). This species of hutia (1.3-6.9 kg) (right) is the most frequently taken prey item of the Cuban Boa in natural habitats, particularly by individuals >2.0 m SVL. Photographs (C) Rafael A. Pérez (left) and Aslam I. Castellón (right).
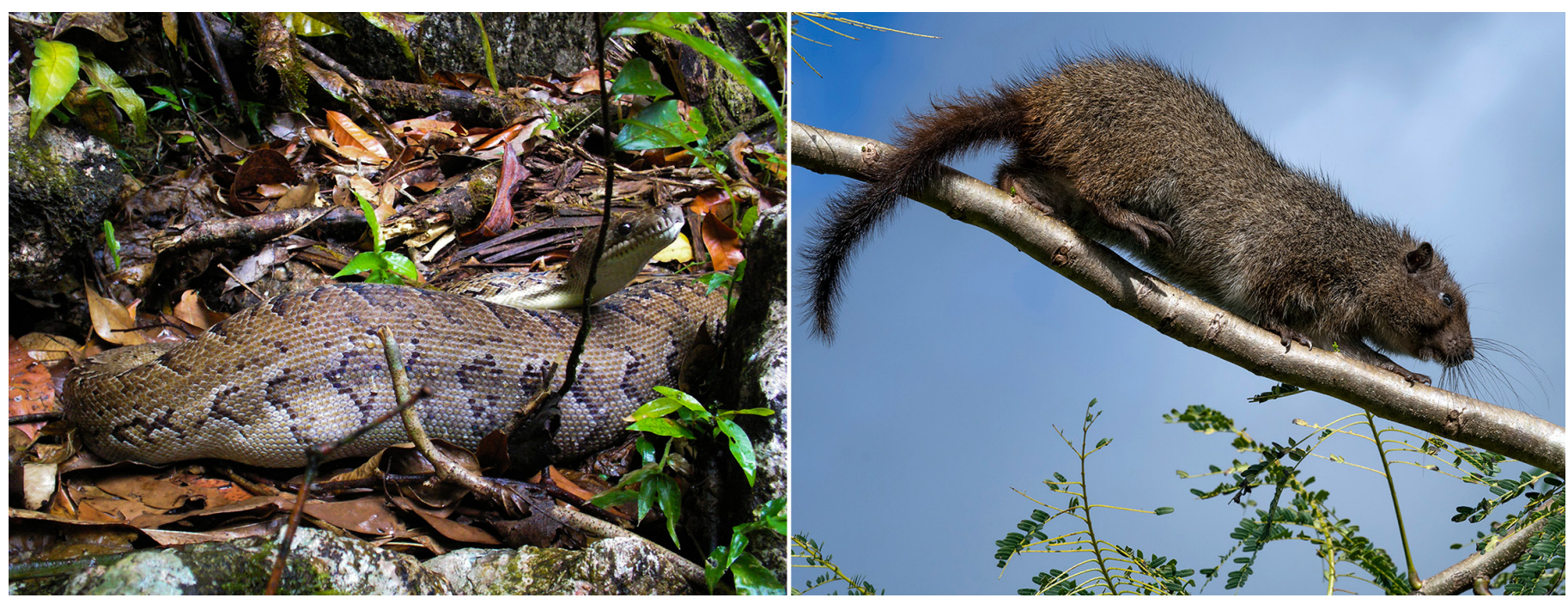

Fig. 9. A medium-sized Cuban Boa (Chilabothrus angulifer) (>2.0 m SVL) containing an adult Black-tailed Hutia (Mesocapromys melanurus) in natural habitat near Farallones, Moa, Holguín Province (left). This species of hutia (1.0-1.6 kg) (right) is restricted to eastern Cuban, is highly arboreal, and lives in family groups of as many as 10 individuals. Photographs (C) Carlos A. Pérez (left) and Samuel Reina (right). 
1 item), were consumed only by juveniles ( $\mathrm{n}=6$ snakes) and subadults/small adults ( $\mathrm{n}=6$ snakes) (Fig. 6). Bats $(\mathrm{n}=70$ items; $\mathrm{n}=26$ snakes) also were consumed only by juveniles ( $\mathrm{n}$ $=5$ snakes) and subadults/small adults $(\mathrm{n}=21$ snakes) (Figs. 6 and 11). Indeed, the smallest measured snake included in this work was a neonate ( $505 \mathrm{~mm} \mathrm{SVL}$ ) found swallowing an adult Cuban Flower Bat (Phyllonycteris poeyi) captured on the wing at a cave entrance in central Cuba (Appendix I).
Ontogenetic shift in diet.-The frequency of prey types consumed by $C h$. angulifer differed significantly between subadults/small adults and medium-sized adults (pseudo$\mathrm{F}_{(1)}=16.014 ; \mathrm{P}=0.0001$; Table 4B; Fig. 6) and also when the habitat type was considered (pseudo- $_{(1)}=19.778 ; \mathrm{P}=$ 0.0001; Table 4B; Fig. 6). The interaction of habitat $\mathrm{x}$ size class also was significant (pseudo- $\mathrm{F}_{(1)}=8.9164 ; \mathrm{P}=0.0001$; Table $4 \mathrm{~B}$ ). After merging and analyzing the data from 152
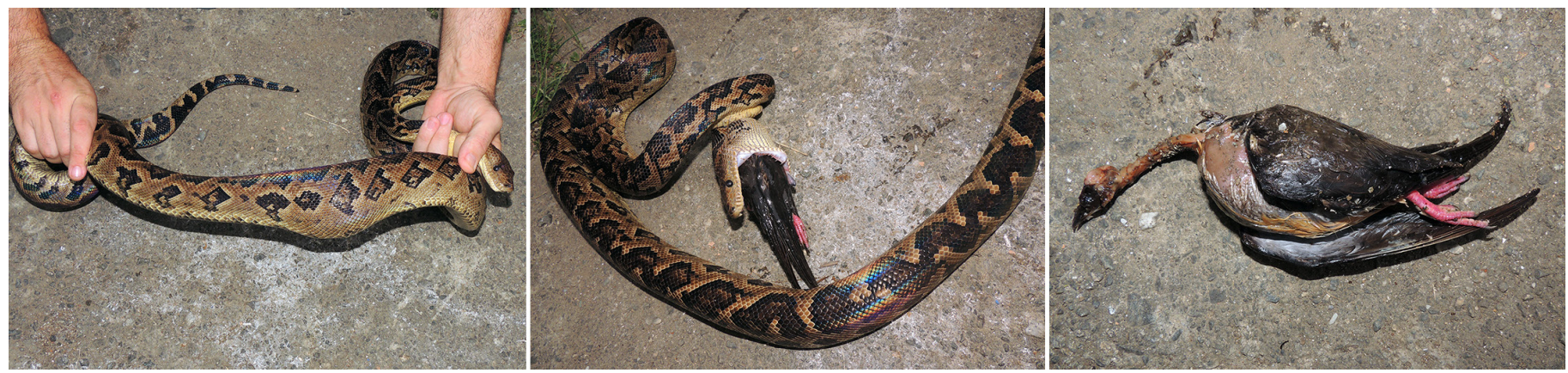

Fig. 10. A small adult Cuban Boa (Chilabothrus angulifer) (ca. $1.5 \mathrm{~m} \mathrm{SVL}$ ) containing a Mourning Dove (Zenaida macroura) (ca. $110 \mathrm{~g}$ ). This snake was in a natural habitat near Fomento, Sancti Spíritus Province. Photographs @ T.M. Rodríguez-Cabrera.
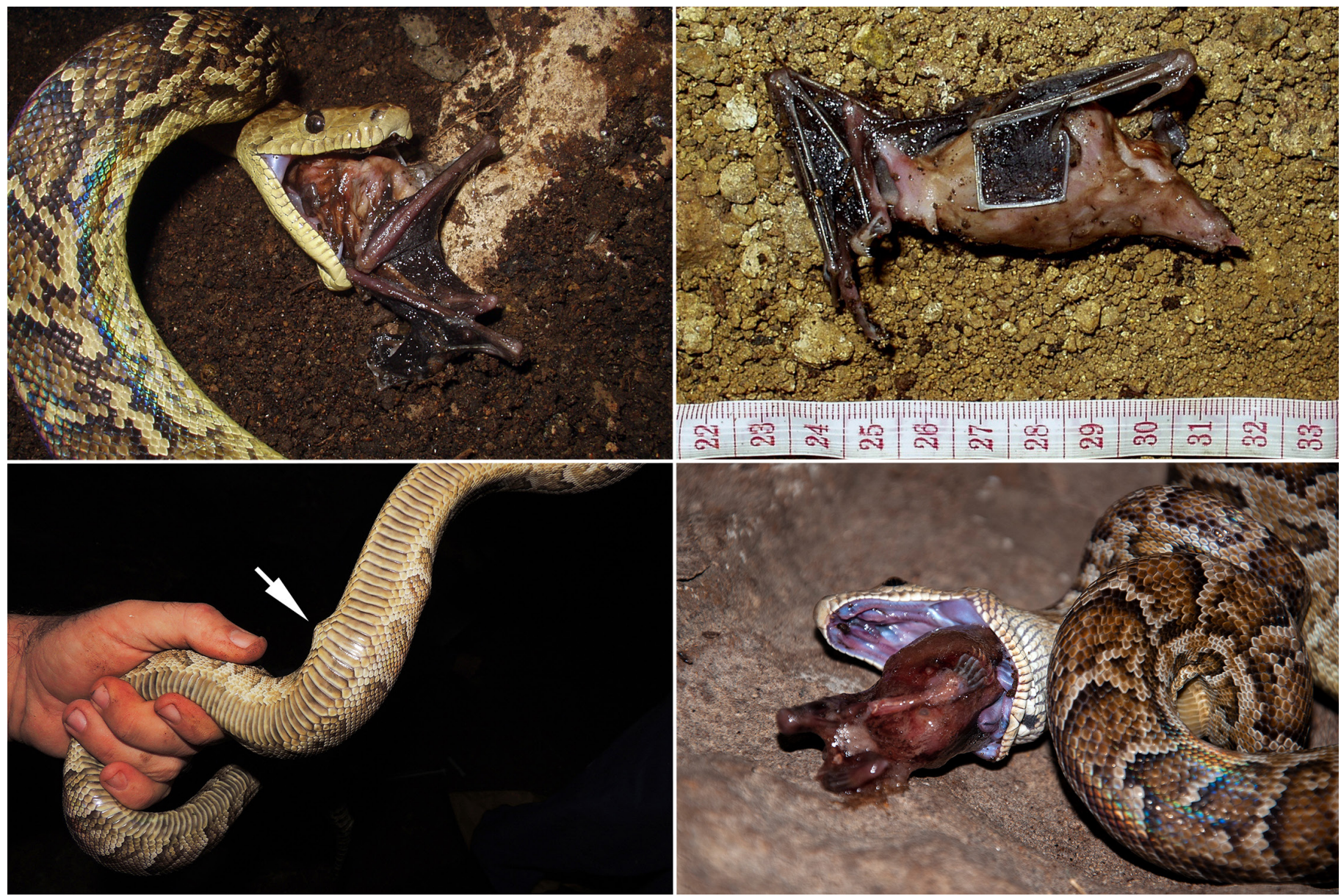

Fig. 11. Sequences of photographs of cave-associated Cuban Boas (Chilabothrus angulifer) containing bats. A sub-adult female (1.245 $\mathrm{m}$ SVL) regurgitating an adult male Buffy Flower Bat (Erophylla sezekorni) (ca. $15 \mathrm{~g}$ ) in "El Abono Cave" in Cariblanca, Sancti Spíritus Province (upper left), with a detail of the bat (upper right; same snake as in Fig. 18 when first captured). Juvenile male (0.93 m SVL) in "Los Majaes Cave" near Galalón, Pinar del Río Province, showing a stomach bulge (arrow) (lower left), and regurgitating an adult male Cuban Flower Bat (Phyllonycteris poeyi) (ca. $20 \mathrm{~g}$ ) (lower right). Photographs (C) T.M. Rodríguez-Cabrera and Alejandro Abella (lower right). 
predation events in both habitat types and for which the sizes of the snakes were known, three trends were evident: (1) Prey size increased with snake size, (2) most prey types were related to snake size, and (3) smaller prey items were omitted from the diets of larger snakes (Fig. 12).

In natural habitats, subadult/small adult snakes $(\mathrm{n}=54)$ consumed 98 prey items and medium-sized snakes $(\mathrm{n}=29)$ consumed 36 prey items; in anthropogenic habitats, subadult/ small adult snakes $(\mathrm{n}=63)$ consumed 84 prey items and medium-sized snakes $(n=30)$ consumed 67 prey items. The prey of subadults/small adults in natural habitats consisted of bats, non-volant mammals, forest birds, and ectotherms. Bats in particular, represented $64.3 \%$ of all prey items consumed by subadults/small adults in this type of habitat ( $\mathrm{n}=63$ items, 21 snakes), followed by small and medium-sized native birds ( $\mathrm{n}=15$ items [15.3\%]; $\mathrm{n}=13$ snakes) (Fig. 6). The diet of medium-sized snakes in natural habitats was comprised largely of hutias, but these snakes also readily took rats and semi-feral domestic fowl. Hutias (Capromys and Mesocapromys) represented $63.9 \%$ of all prey items consumed by medium-sized snakes in natural habitats ( $\mathrm{n}=23$ items; $\mathrm{n}=17$ snakes), but for subadult/small adult snakes, hutias $(\mathrm{n}=4$ items $[4.1 \%] ; \mathrm{n}=4$
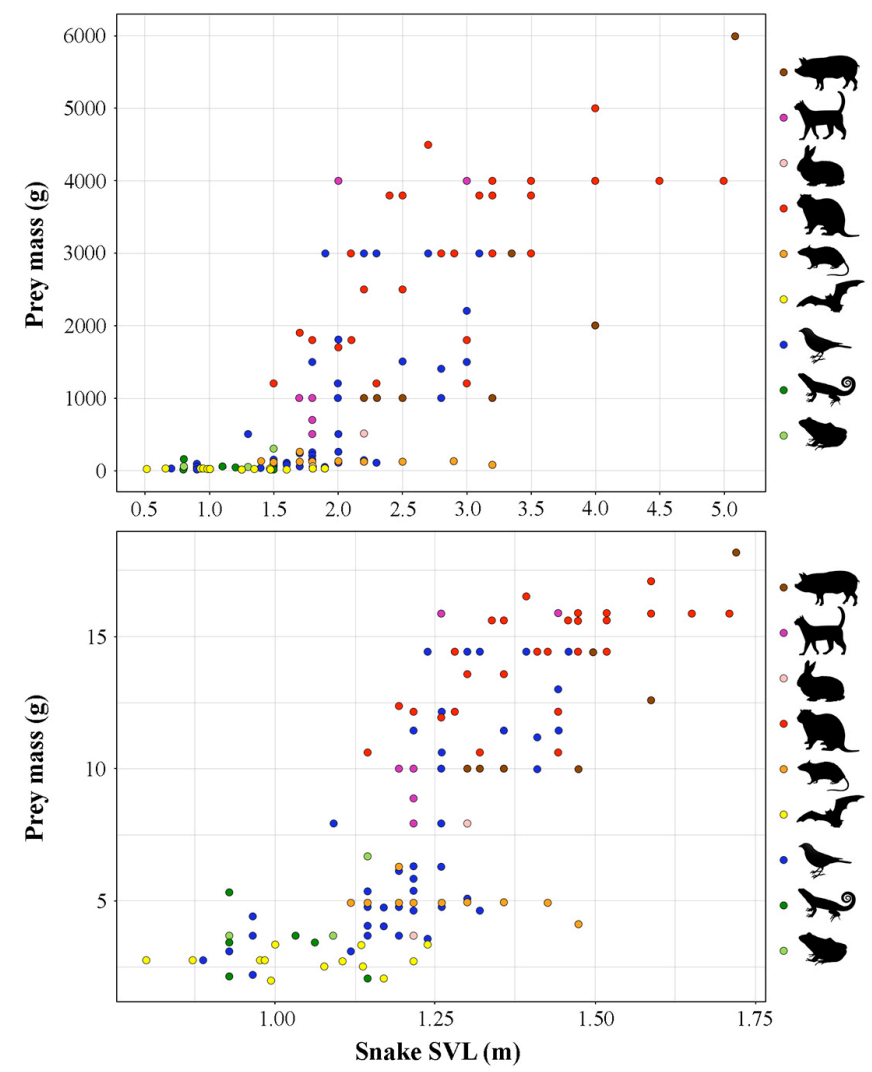

Fig. 12. Relationships of prey size and snake size in 152 Cuban Boas (Chilabothrus angulifer). Data on the original scale (above) and after a cube-root transformation (below). Notice the general trend of larger snakes consuming larger prey items and omitting smaller prey items such as bats and ectotherms from their diets. Prey types in the legend are (from below to above): amphibians, reptiles, birds, bats, rats, hutias, rabbits, carnivores, and artiodactyls. snakes) made up only a small proportion of prey items taken, and those instances always involved young hutias.

The diet of subadult/small adult snakes in anthropogenic habitats included mostly small, medium-sized, and large birds, but also ectotherms, rats, and domestic mammals (Fig. 6). Medium-sized domestic birds ( $\mathrm{n}=44$ items [52.4\%]; 38 snakes), including adult and nestling domestic pigeons (Columba livia) and small adult poultry (Cairina, Gallus, Meleagris, and Numida), were taken most frequently by subadults/small adults. The diets of medium-sized snakes in anthropogenic habitats included most of the prey types consumed by subadult/small adult snakes, but the proportions were different. The prey types most frequently consumed by medium-sized snakes in this type of habitat were small, medium-sized, and large birds in similar proportions, altogether comprising $71.6 \%$ of the total number of prey items consumed ( $\mathrm{n}=48$ items; $\mathrm{n}=24$ snakes). Medium-sized snakes also took a small number of suckling pigs. Domestic chickens represented $53.6 \%(\mathrm{n}=45$ items; $\mathrm{n}=37$ snakes $)$ and $55.2 \%$ ( $\mathrm{n}=37$ items; $\mathrm{n}=21$ snakes) of the total number of prey items consumed by medium-sized adult and mediumsized snakes, respectively, in anthropogenic habitats.

Rats were consumed in similar proportions by subadult/ small adult snakes in both natural $(\mathrm{n}=9$ items [9.2\%]; $\mathrm{n}=9$ snakes) and anthropogenic habitats $(\mathrm{n}=7$ items [8.3\%]; $\mathrm{n}=$ 7 snakes). Eight medium-sized snakes in natural habitats consumed eight rats (22.2\% of the total number of prey items), but we found no medium-sized boas in anthropogenic habitats that had consumed rats.

We did not include juvenile snakes in the statistical analyses to test the ontogenetic shift in diet hypothesis because of small sample sizes (natural habitats: $\mathrm{n}=14$ items, $\mathrm{n}=12$ snakes; anthropogenic habitats: $\mathrm{n}=10$ items, $\mathrm{n}=5$ snakes). However, our few observations are worth mentioning. In natural habitats, juvenile snakes consumed ectotherms and endotherms in comparable numbers, whereas in anthropogenic habitats, juveniles consumed exclusively small caged birds (i.e., Agapornis, Lonchura, Melopsittacus, Psittacara, and Spindalis) (Table 1; Fig. 6). Similarly, we had a small sample size of large adult snakes in anthropogenic habitats $(n=6$ items; $\mathrm{n}=6$ snakes). The few individuals belonging to this size class in this type of habitat primarily consumed large domestic fowl and suckling artiodactyls, such as pigs, goats and sheep, whereas in natural habitats, large adults $(\mathrm{n}=36$ items; $\mathrm{n}=19$ snakes) consumed hutias, rats, and semi-feral suckling pigs (Fig. 6). Hutias were consumed in a similar proportion by medium-sized and large adult snakes ( $\mathrm{n}=23$ items [63.9\%]; $\mathrm{n}=15$ snakes) in natural habitats (Fig. 6). Snakes in these size classes did not consume ectotherms or bats in any type of habitat.

Foraging strategy.-We documented 45 snakes in natural habitats and 50 in anthropogenic habitats engaged in preda- 
tion events (Table 3). In 32 of the events in natural habitats and in 48 of the events in anthropogenic habitats, we determined the foraging mode used. We found that foraging strategy was not independent of habitat type $\left(\chi^{2}=33.148\right.$, $\mathrm{df}=1, \mathrm{P}=8.542 \mathrm{e}-09)$. Twenty snakes $(62.5 \%)$ employed an ambush strategy and 12 snakes (38.7\%) used an activeforaging mode in natural habitats. At least in one additional case involving stomach contents (juvenile bats) in a natural habitat, the snake must have used an active foraging strategy (see below). In all but one predation event observed in anthropogenic habitats and, in most if not all of the cases of stomach contents in this type of habitat, the snakes must have used an active foraging strategy (see below). Foraging time was not independent of habitat type $\left(\chi^{2}=29.513, \mathrm{df}=\right.$ $1, \mathrm{P}=5.553 \mathrm{e}-08)$. More than half of the snakes engaged in predation events ( $\mathrm{n}=27$ snakes, $60.0 \%$ ) in natural habitats did so by day, whereas only $18(40.0 \%)$ events were nocturnal (Table 3). All but three snakes engaged in predation events in anthropogenic habitats were found at night (96\%; Table 3), and one of the cases found by day (constricting a rat) was in a sewer in complete darkness (Appendix I).

The snakes that were found consuming ectotherms in natural habitats apparently used both sit-and-wait and activeforaging strategies, in particular five juveniles preying on Cuban Treefrogs by day and another juvenile eating an anole at night (Table 3). Since these frogs are nocturnal and anoles are diurnal, in all instances the snakes must have actively searched for inactive prey. A small adult captured a hatchling Cuban Slider in its nest just after hatching and emergence (Tables 1 and 3). The foraging strategy used in the remaining cases involving ectotherms is uncertain.

Four of the snakes found in natural habitats were consuming forest birds by day and possibly used a sit-and-wait foraging mode. The prey items included a Greater Antillean Grackle (Quiscalus niger), a Great Lizard Cuckoo (Coccyzus merlini), a Red-legged Thrush (Turdus plumbeus), and a Zenaida Dove (Zenaida aurita) (Table 3). The boas, which apparently had been laying in ambush on the forest floor, were observed at the precise moment they captured the birds. Two other snakes probably used an active foraging mode to find two Cave Swallow (Petrochelidon fulva) eggs and a nestling Gray Kingbird (Tyrannus dominicensis) (Appendix I).

Four subadult/small adult snakes and one medium-sized snake were observed consuming rats in natural habitats by day (Table 3). Because rats are primarily nocturnal, most of the snakes in those cases probably used an active-foraging mode to find sleeping rats. At least in one case, a boa was observed stalking and eventually capturing a rat in a hollow tree on the Guanahacabibes Peninsula (R. Varela, pers. comm. 5.v.2020).

A boa approaching $2.0 \mathrm{~m} \mathrm{SVL}$ was observed swallowing an adult feral cat (ca. $4.0 \mathrm{~kg}$ ) early in the morning at the entrance of a hot cave near Galalón, Pinar del Río Province
(R. Martínez, pers. comm. 31.i.2017). Prior to that observation, bat remains (wings) were frequently observed at the cave entrance, a typical sign of bat predation by cats. Only one cat might have been feeding on bats in that cave, as no more bat remains were observed after that cat was eaten by the boa.

All observed predation events involving Desmarest's Hutias in natural habitats took place by day. Five snakes were observed constricting or swallowing hutias on the forest floor or on limestone rocks usually associated with karstic environments, two snakes captured the hutias in trees and fell to the ground while constricting their prey, and one snake was swallowing a hutia in a grassland by a beach (Table 3; Appendix I). The foraging strategy employed in these cases is unknown since $C a$. pilorides is active by both day and night.

Most snakes observed while engaged in predations events in natural habitats ( $\mathrm{n}=16$ snakes, $36.4 \%)$ were consuming bats associated with caves harboring large bat colonies. These snakes used a sit-and-wait foraging strategy. Bat-hunting always occurred in complete darkness, starting approximately 30-60 min after sunset. In some caves, boas employed two hunting sessions per night, one after sunset and another before sunrise. Snakes may take positions either in the usually narrow cave passages leading to the exit, right at the exit, or in vegetation immediately outside the cave. Boas may hang from rock crevices or coil around rock projections (e.g., stalactites) on the cave's ceiling, around vines, branches, or aerial roots, but always in the pathway of the bats (Fig. 13). Alternatively, snakes may position themselves on the ground or climb onto a rock shelf or into a crevice in the cave chambers and passages where bats roost; in such instances, they typically elevate the anterior third of the body (Fig. 13). This appears to be especially effective when the cave roof is low enough to force the bats to fly near the ground. This same strategy is sometimes used by day as well, when for some reason (e.g., human intrusion), the bats becomes agitated and fly in circles around the chambers without leaving the cave. Contact with the extended portion of the snake's body is necessary to trigger its attack, which consists of a rapid swing with the mouth open toward the origin of the impact. Once a bat is captured, the boa rapidly wraps it in one or two coils and begins the swallowing process, either while hanging or after capturing the bat from the ground (Fig. 14). Apparently, some boas capture multiple bats during a single hunting session. We observed at least one boa on a cave floor constricting and swallowing two freshly captured adult Buffy Flower Bats (Erophylla sezekorni). In addition to the successful predation events recorded, similar scenarios have been repeatedly observed by the authors in bat caves across the island, without necessarily confirming successful predation. All of the captured bats were phytophagous phyllostomids (Jamaican Fruit-eating Bats, Artibeus jamaicensis, Cuban Fruit-eating Bats, Brachyphylla nana; Buffy Flower Bats, Erophylla sezekorni, or Cuban Flower Bats, Phyllonycteris poeyi) (Table 3). 


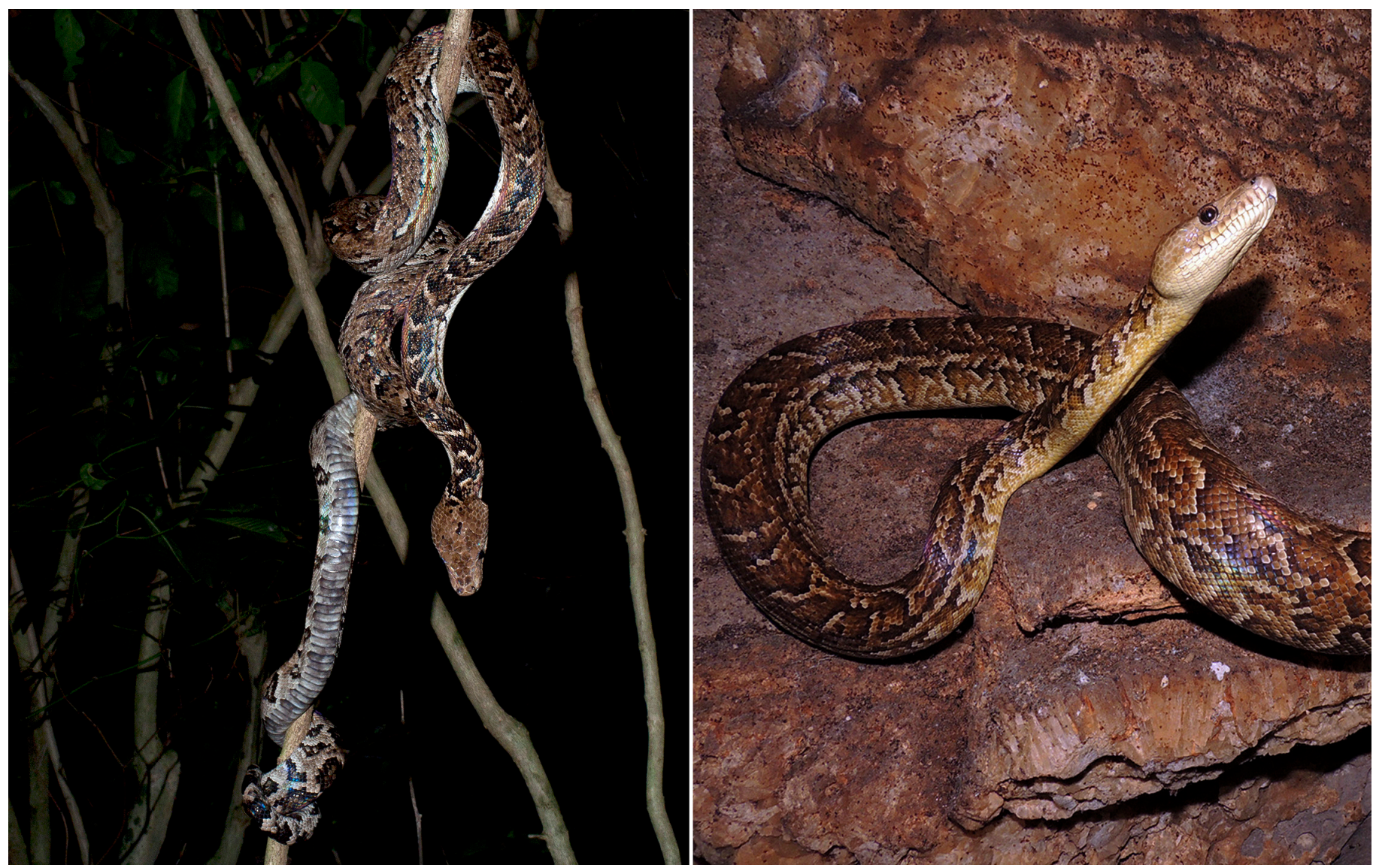

Fig. 13. Two basic positions adopted by cave-associated Cuban Boas (Chilabothrus angulifer) when foraging for bats. The anterior third of the body hanging down (left) or with a comparable portion of the body elevated (right). Photographs (C) Raimundo López-Silvero (left) and T.M. Rodríguez-Cabrera (right).

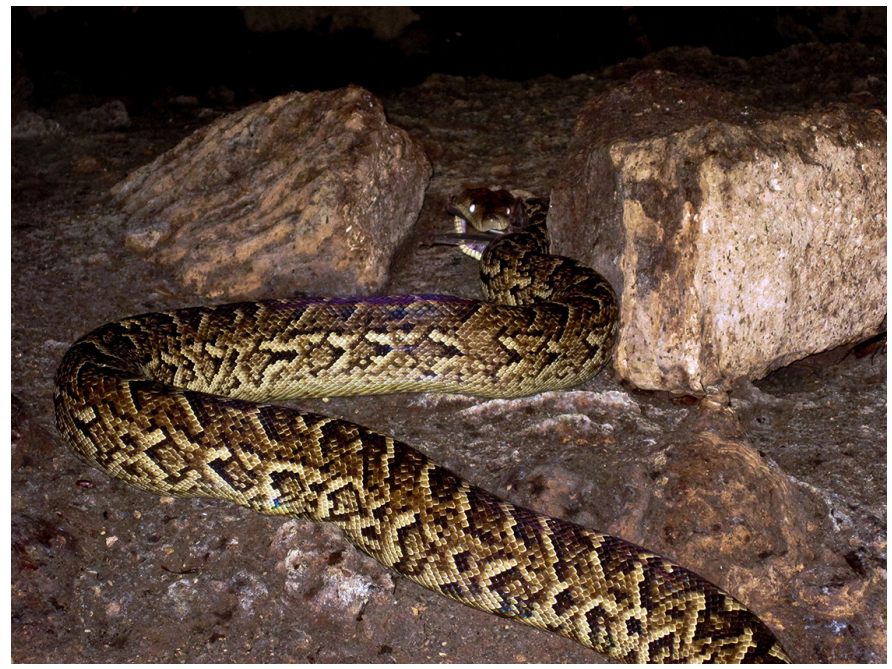

Fig. 14. A small adult Cuban Boa (Chilabothrus angulifer) $(<2.0 \mathrm{~m}$ SVL) swallowing a freshly captured unidentified bat (possibly a Cuban Flower Bat, Phyllonycteris poeyi) on the floor of the same cave studied by Hardy (1957) at Guanayara, west of Trinidad in Sancti Spíritus Province. Photograph @ Haydée González.

Other than the 50 predation events we recorded, most snakes with stomach contents in anthropogenic habitats consumed recognizable domestic animals the night (or a few nights) before they were found. These boas apparently used an active-foraging strategy. Domestic chickens, the most frequently taken prey species in anthropogenic habitats, roost in groups on tree branches, sometimes forming mixed roosting groups with other species (Fig. 15). Hens and chicks sleep on the ground during the first weeks after hatching but, as soon as the wing feathers of the chicks emerge, the mother hen begins to entice the chicks into the trees before sunset. Four snakes were observed preying on chicks hidden under hens while sleeping on the ground; only on one occasion was the snake large enough $(>2.0 \mathrm{~m} \mathrm{SVL})$ to consume both the hen and eight small chicks (A. Hernández, pers. comm. 2013). In most cases, the snakes managed to slip under the hen and take only some of the chicks. Forty snakes preyed on poultry from roosting groups in trees at night. In these cases, the snakes climbed into the trees, captured, coiled around a roosting bird, and usually dropped to the ground to constrict and swallow their prey. On only a few occasions, when the birds were relatively small, did the snakes initiate ingestion while in the trees. Most predation events involving this kind of prey occurred before midnight. Local farmers and landowners stated that domestic chickens apparently are able to detect the presence of a boa, even in complete darkness, since they usually produce an alarm call. Only one snake, which 

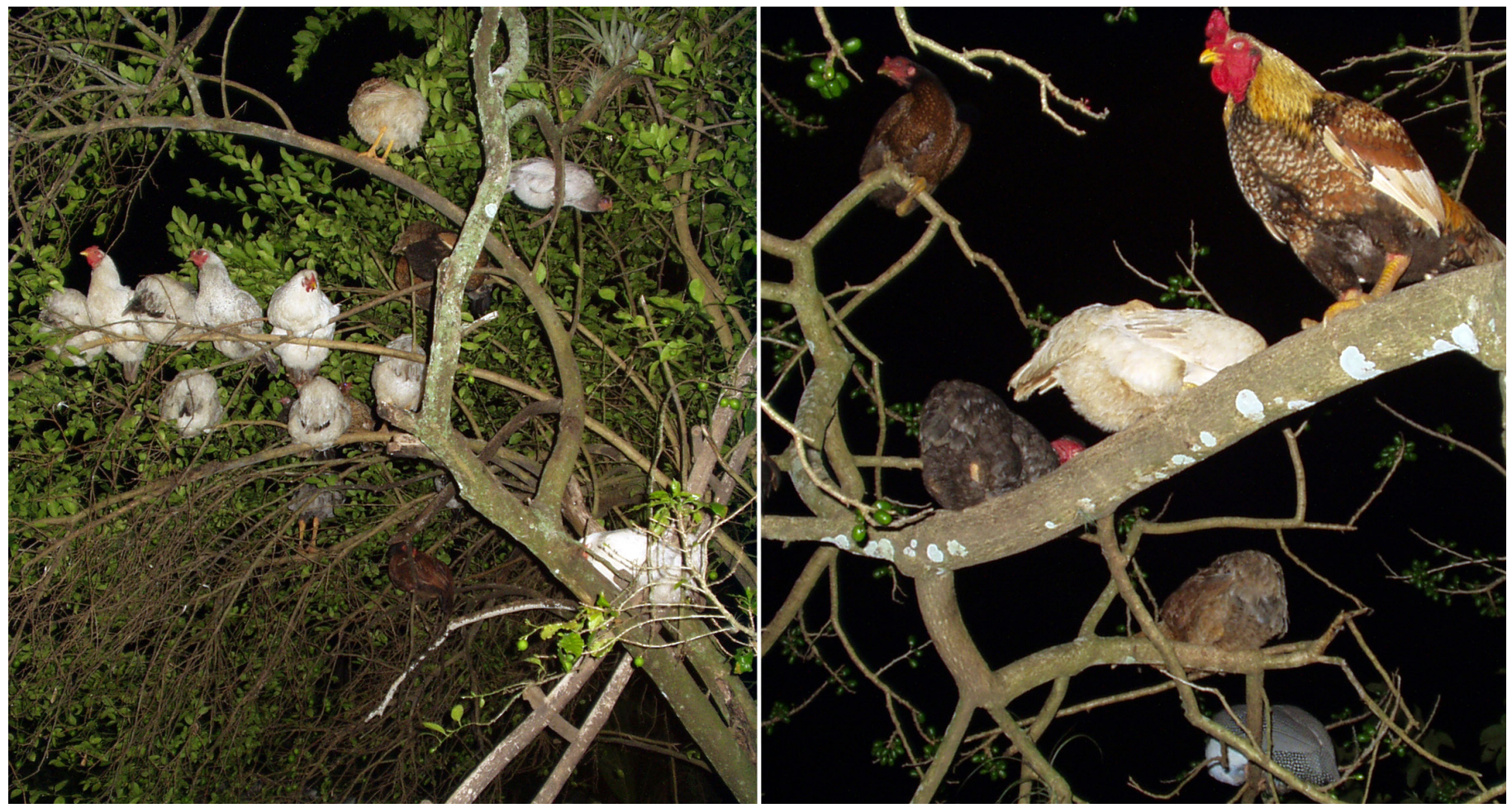

Fig. 15. Poultry on nocturnal roosting perches are typically observed in anthropogenic habitats in Cuba. Predation on domestic fowl by Cuban Boas (Chilabothrus angulifer) occurs frequently in such conditions. Rustic wooden ladders (left) to help poultry access the roosting sites also facilitate access by boas. Photographs (C) T.M. Rodríguez-Cabrera.

apparently had used an ambush-foraging mode was observed preying on a young rooster in an urban area by day (Fig. 16).

Other domestic animals such as caged birds, cats, dogs, and pigs were taken from diverse places in or around buildings and farms while asleep. Although Helmeted Guineafowl (Numida meleagris) may be as common as chickens (Gallus gallus) on many farms, the incidence of predation on this species was much lower and involved mostly young birds (Tables 1 and 3). In places with a high incidence of boa predation (e.g., Cariblanca; Fig. 2), we observed adult Guineafowl (with a better flight capacity) choosing higher roosting sites (often $>8 \mathrm{~m}$ above the ground) than those selected by domestic chickens (with a poorer flight capacity), which usually perch at heights of $1-4 \mathrm{~m}$. Also, Guineafowl seemed to show a preference for trees with longer, thicker, vertical trunks without forks, whereas chickens frequently perch on trees or bushes with shorter, thinner, sloping trunks, often with associated rustic wooden ladders, that are more accessible for snakes (Fig. 15).

A common situation involving caged birds (i.e., Caracara, Columba, Coturnix, Gallus, Lonchura, Melopsittacus, Psittacara, Spindalis; $\mathrm{n}=10$ snakes) and mammals (i.e., European Rabbits, Oryctolagus cuniculus, $\mathrm{n}=2$ snakes) involved snakes slipping into cages between the bars. However, they subsequently were unable to escape due to the newly acquired prey bulge and were found coiled in the cages the next day.

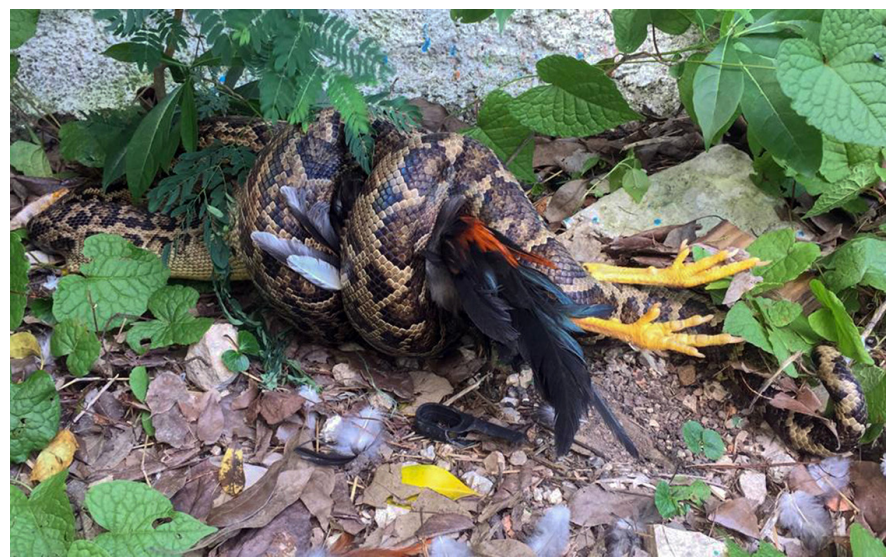

Fig. 16. A Cuban Boa (Chilabothrus angulifer) (ca. $2.0 \mathrm{~m}$ SVL) preying on a young rooster (Gallus gallus) in a backyard in La Habana by day. In this case the snake likely used an ambush-foraging strategy. Photograph (C) Elsa M. Hiralda.

Over 30 observations involved adult and subadult domestic chickens $(>2.0 \mathrm{~kg})$ freshly killed in anthropogenic habitats with the anterior parts of their bodies (head, neck, and shoulders) covered by saliva. Local farmers and landowners recognized this as signs of failed predation attempts by Ch. angulifer. In these cases, the boas apparently were strong enough to subdue and kill their prey but lacked sufficient gape size to swallow them. Farmers and landowners in the 
countryside coined the term "chupados" (i.e., sucked) for these dead chickens.

\section{Discussion}

The usually low population densities and the secretive habits of Cuban Boas render observations of predation in nature very difficult. Nevertheless, a number of historical references address the diet of Chilabothros angulifer (Appendix I). These fall into three more-or-less well defined periods: (1) The first decades of conquest (early 16th century) are represented by mostly ambiguous observations of West Indian chroniclers; (2) the mid-19th to mid-20th centuries also are represented by anecdotal observations but these tend to be more accurate since they were generated by naturalists; and (3) the mid-20th century to the present, represented by more accurate and detailed information. A complete gap of information exists between the early 16th and mid-19th centuries.

Most observers noted that Ch. angulifer is a predator of native birds, hutias, rats, and domestic animals. Before the mid-20th century, only a handful of papers made reference to specific cases of predation by free-ranging boas. Other works merely listed Ch. angulifer among confirmed predators of certain species without quantitative information. These include several popular articles, research project reports, and online publications related to the U.S. Naval Base at Guantánamo Bay that identified the Cuban Boa as the principal predator of hutias and other species (Appendix I).

Extensive studies on the feeding habits of large constrictors are frequently based on data from the literature and stomach contents from museum specimens, often collected over a span of several years (Henderson et al. 1987; Slip and Shine 1988; Fearn et al. 2001; Pizzatto et al. 2009). Dietary studies conducted in specific areas during relatively short periods of time are scarce (Shine and Fitzgerald 1996; Shine et al. 1998; Luiselli et al. 2001; Quick et al. 2005). Chilabothrus angulifer is poorly represented in Cuban museum collections mostly due to preservation constraints (Rodríguez et al. 2013; Rodríguez-Schettino et al. 2014; L.M. Díaz and A. Fong, in litt., 2020). Moreover, many snakes that became museum specimens were first kept in captivity for extended periods, so the use of museum specimens for extensive dietary studies on this boa is impractical.

General dietary composition and niche breadth.Chilabothrus angulifer showed a narrow niche breadth $\left(B^{\prime}=\right.$ 0.319 ), consistent with that of a trophic specialist (Schoener 1971; Hurlbert 1978). This result was unexpected for a predator that consumes as many as 49 different prey species (Table $1)$, even after condensing those species into 16 resource categories. When analyzed separately, the trophic niche breadth of $C h$. angulifer in natural habitats $\left(B^{\prime}=0.321\right)$ was similar to the overall niche breadth, but that of boas associated with anthropogenic habitats was narrower $\left(B^{\prime}=0.135\right)$. The real- ity that most boas exploited only a few different types of prey and that many of those were taken only sporadically explains the narrow trophic niche of the species. Nonetheless, rather than a trophic specialist, Ch. angulifer appears to be an opportunistic predator, capable of adjusting its diet and foraging behavior according to prey availability, abundance, and characteristics of the habitat. Despite the relatively narrow value of niche breadth, we refrain from rejecting the hypothesis that Ch. angulifer is a generalist predator for two main reasons: (1) Trophic specialists do not typically consume such a variety of prey species and (2) do not change their diets when in different habitat types (see below), especially when the change of habitat involves moving to human-altered environments (moves that would be of little evolutionary significance).

A general trend of exploiting the most abundant prey in each type of habitat was evident. The few prey species that form a major portion in the diet of Ch. angulifer in natural habitats show some degree of gregariousness and may reach high population densities. All of the species of bats exploited by boas form colonies that range from a few hundred to hundreds of thousands of individuals (Silva 1979) (Fig. 17). Hutias may form family groups comprised of as many as 10 individuals (see Silva et al. 2007 for a review). Under favorable conditions, $C$ a . pilorides may reach population densities of 35.6-73.6 hutias/ha in inland second-growth forests to 78.0-153.3 hutias/ha in mangrove forests (Comas et al. 1989, 1994; Comas and Berovides 1990; Berovides and Comas 1997a, 1997b; Borroto-Páez and Mancina 2006; see Silva et al. 2007 for a review). House Rats are ubiquitous and also may achieve high population densities. Borroto-Páez et al. (1990) and Borroto-Páez (2011a, 2013) found as many as 14 rats/ha in Cuban sugarcane plantations. Gundlach (1880) also had mentioned the benefits of Cuban Boas reducing the impact of murid rodents in sugarcane plantations.

Although we could not include White-crowned Pigeons (Patagioenas leucocephala) in our statistical analyses due to the lack of quantitative data, these birds are highly gregarious and may form nesting colonies of 20,000 to more than 200,000 breeding adults and as many as 300 or more active nests/ha (Vázquez and Nieves 1980; Chamizo et al. 1983; Godínez et al. 1987; Godínez and Vinola 1988; Godínez 1993). The number of chicks per nest is normally two (range: $1-3$ chicks). Chicks reach the fledgling stage ( $>200 \mathrm{~g}$ ) two weeks after hatching (see Godínez 1993 for a review). Chilabothrus angulifer is a known predator of both eggs and chicks (Vázquez and Nieves 1980; Godínez et al. 1987), but certainly preys on adults as well. Local people and hunters have killed boas containing one or more adult pigeons at nesting colonies located about $10 \mathrm{~km}$ east of Jagüey Grande, Matanzas Province, and at "La Javira," about $5.5 \mathrm{~km}$ south of Topes de Collantes, Sancti Spíritus Province (R. Chamizo, in litt. 8.iv.2020). Those nesting colonies were extirpated in recent 

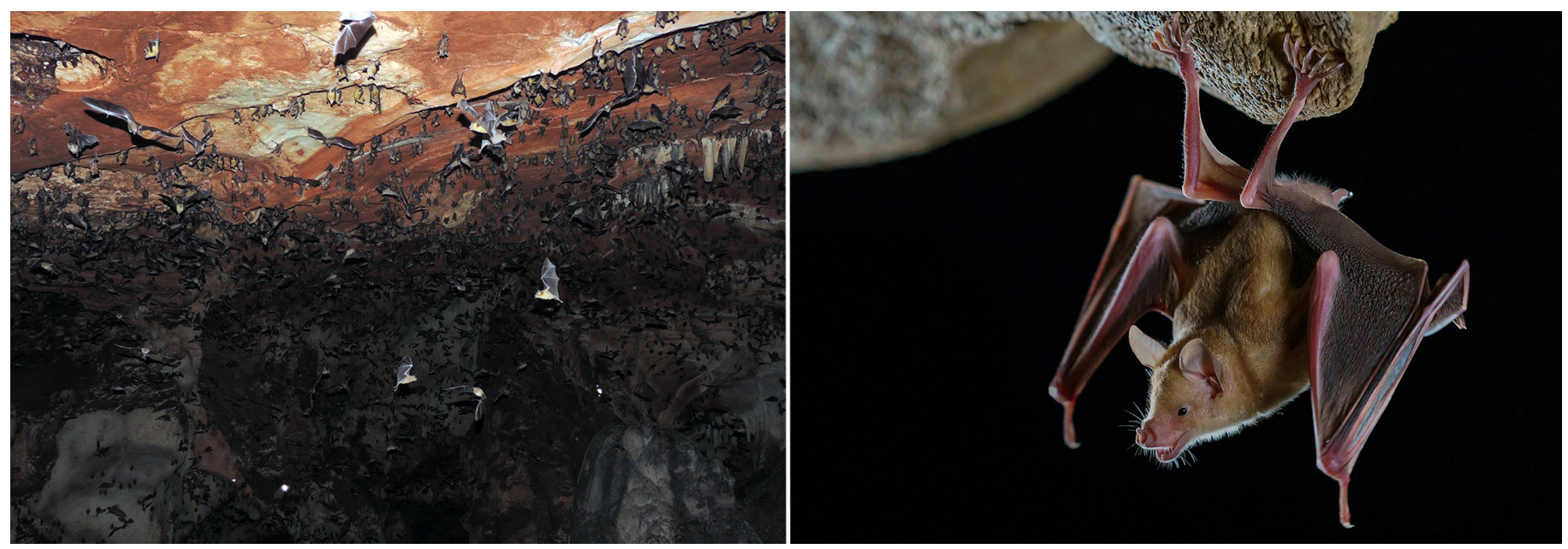

Fig. 17. Phytophagous phyllostomid bats may form aggregations in caves ranging from a few hundred to hundreds of thousands of individuals (left). The Cuban Flower Bat (Phyllonycteris poeyi) (right) is one of the most gregarious species of bats in Cuba and one of the most frequently consumed by Cuban Boas. Such large aggregations represent important concentrations of food for these snakes. Photographs (C) T.M. Rodríguez-Cabrera (left) and Aliesky del Río (right).

years due to deforestation, agriculture, stockbreeding, chick predation, and construction of roads and tourist facilities (Acosta and Mugica 2019; R. Chamizo, in litt. 20.v.2020). However, other nesting colonies remain active in a few locations in western Cuba, on Isla de la Juventud, and on some cays (Acosta and Mugica 2019), providing opportunities to study predation by $C h$. angulifer.

Several species of herons in Cuba also form nesting colonies that might contain 800 to 8,000 nests/ha (Denis 2002). Although $C h$. angulifer has not been reported preying on nestling or adult herons, some evidence suggests that it might exploit this food source as well. On 7 June 2001, a small adult boa (1.4-1.5 $\mathrm{m}$ total length) with a stomach bulge was found coiled in the fork of a Black Mangrove (Avicennia germinans) at "Wiso Colony" near the Cauto River Delta (Fig. 2) in Granma Province (D. Denis, pers. comm. 2013; for more details about this nesting colony see Denis 2001, 2002, 2006a, 2006b; Denis et al. 2003). Based on bulge size (too small to be an adult heron or a hutia), this boa must have ingested a medium-sized Cattle Egret (Bubulcus ibis) chick $(>100 \mathrm{~g})$. Cattle Egrets are the most abundant species nesting in the area (D. Denis, pers. comm. 2013; see also Denis 2001, 2002; Denis et al. 2003). However, the identity of the prey was never corroborated. In mangroves in southern Las Tunas Province (Fig. 2), boas with visible stomach bulges occasionally may be observed resting on branches or in hollow trunks close to nesting colonies that include those of various species of herons, Anhingas (Anhinga anhinga), and White Ibises (Eudocimus albus) (M. Alonso, in litt., 16.vi.2020). Wiley (2003) observed a Puerto Rican Boa (Ch. inornatus, $1.67 \mathrm{~m}$ SVL) consuming an egg and a hatchling Cattle Egret on a cay in Bahía Montalva, Puerto Rico. Daniel (2002) suggested that Indian Pythons (Python molurus) exploit bird concentra- tions such as those in "heronries, nesting colonies and large bird roosts."

Given that poultry is the most frequently taken prey item in anthropogenic habitats, the fact that nearly $70 \%$ of the boas found in those habitats consumed poultry is not surprising. Domestic chickens (G. gallus), the most common poultry species on Cuban farms, represented more than half of the prey items consumed by boas in this type of habitat. Predation by Ch. angulifer on poultry and other domestic animals such as pigeons, turkeys, and suckling pigs was mentioned repeatedly in the older literature without quantitative details (Appendix I). The diet of boas associated with natural habitats suggest that exploitation of concentrated food resources (e.g., bat colonies) are critically important. Large aggregations of birds and mammals, once they become stationary for reproductive and/or roosting purposes, generate considerable amounts of organic waste (i.e., urine, feces, carcasses, broken eggs, feathers, hair) that could be detected chemically. Snakes are well known for responding to chemical cues of potential prey (Ford and Burghardt 1993). Although domestic animals have appeared only recently, most farms could be considered large concentrations of food every bit as enticing as a bat colony, a family group of hutias, or a nesting colony of birds. Ottenwalder (1980) recorded Hispaniolan Boas (Ch. striatus) preying on birds in a free-flight aviary at the National Zoo in Santo Domingo, Dominican Republic (see also Henderson et al. 1987). Sheplan and Schwartz (1974) related the high abundance of Bahamian Boas (Ch. strigilatus) on Eleuthera Island in the Bahamas to the poultry-raising industry that once existed on that and other islands and noted that these boas are known as "fowl snakes" throughout the Bahamas. Domestic chickens also have been reported in the diets of Turks \& Caicos Boas (Ch. chrysogaster), Puerto Rican Boas, 
and Jamaican Boas (Ch. subflavus) (Gosse 1851; Rivero 1978; Schwartz and Henderson 1991; Wiley 2003).

Cuban Boas seem to show a high fidelity to sites with abundant and stable food resources. Rodríguez-Cabrera et al. (2016b) recaptured eight marked individuals associated with a hot cave in central Cuba three $(\mathrm{n}=2)$, six $(\mathrm{n}=3)$, nine ( $\mathrm{n}$ $=1)$, and $12(\mathrm{n}=1)$ months after being marked, and one was recaptured twice (during the 3rd and 9th months). On 23 January 2012, 14 boas were marked in "Erophylla Cave," northwest of Yaguajay, Sancti Spíritus Province. Four of those boas were recaptured in the same cave on 5 July 2012 (ca. 5.5 months later) and one was recaptured on 14 January 2019 (ca. 7 years later; T.M. Rodríguez-Cabrera, unpubl. data). Three more boas marked in "El Abono Cave" at Cariblanca in January and April 2013 were recaptured in the same cave in December 2017 (ca. 5 years later; T.M. RodríguezCabrera, unpubl. data; Fig. 18). Puente-Rolón and Bird-Picó (2004) observed a similar pattern in cave-associated Puerto Rican Boas. After implanting transmitters in nine boas and tracking them over a 10 -month period, they observed that all but one boa remained in the vicinity of the bat cave where they were first captured and visited the cave repeatedly during the study period. No comparable data exist for boas associated with anthropogenic habitats, where the survival rate must be much lower due to human persecution. However, repeated loss of domestic animals of approximately the same size at regular intervals of about $8-10$ days was often followed by the detection of a boa (T.M. Rodríguez-Cabrera, pers. obs.). Although such evidence is at best circumstantial, the fact that domestic animals went missing without signs indicative of avian or mammalian predation at intervals that more-or-less coincide with the digestion time of boas certainly is suggestive of boa predation. Those observations also suggest that
Ch. angulifer might show some degree of fidelity to food-rich anthropogenic habitats.

Consumption of bird eggs by species of Chilabothrus seems to occur infrequently (Koenig et al. 2007). Cuban Boas are reported to have consumed eggs of only two species, White-crowned Pigeons (Godínez et al. 1987; Godínez 1993) and Cave Swallows (Petrochelidon fulva) (Mancina and Llanes 1997). As noted above, Wiley (2003) reported a medium-sized Puerto Rican Boa consuming a Cattle Egret egg. Ottenwalder (1980) also reported predation on 13 Ring-necked Pheasant (Phasianus colchicus) eggs and on an egg (and an adult) of a Hispaniolan Parakeet (Psittacara chloropterus) in the previously mentioned free-flight aviary at the National Zoo in Santo Domingo, Dominican Republic. Schwartz and Henderson (1991) recorded consumption of chicks and eggs of domestic chickens by Turks \& Caicos Boas. Because eggshells eventually collapse in a snake's stomach or are expelled after fluid ingestion, the only ways to document egg predation is to encounter a snake in the act or by dissection of dead snakes. Consequently, egg predation could occur more frequently than the few reports suggest. Martins and Oliveira (1998) found two avian eggshells collapsed in the stomach of a juvenile Rainbow Boa (Epicrates cenchria) and Ferreto and Sifuentes (2019) observed predation by another Rainbow Boa on two eggs of the groundnesting Gray Tinamou (Tinamus tao).

Diets in natural and anthropogenic habitats.-The feeding habits of $C h$. angulifer changed dramatically from a diet based largely on native mammals and birds in natural habitats to a diet mostly comprised of livestock, pets, and human commensals when in human-altered environments (Table 1; Figs. 5 and 6). Those results support the hypothesis that diets in natural and anthropogenic habitats differ.
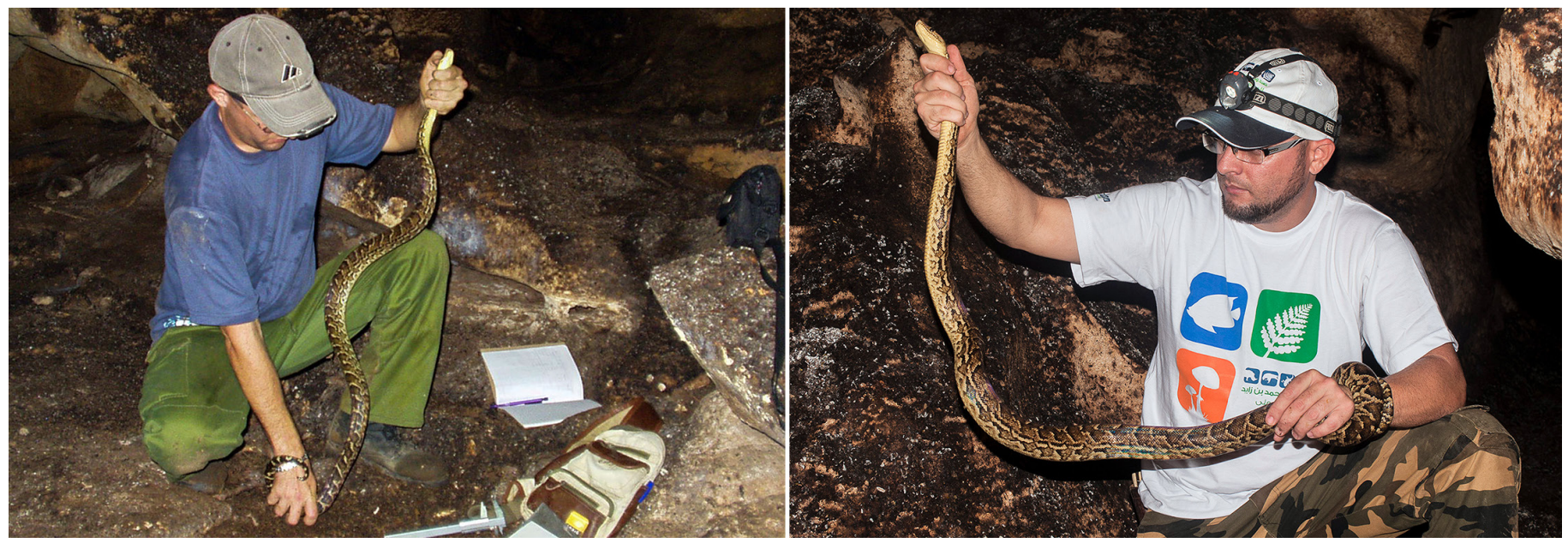

Fig. 18. The senior author holding an average-sized, cave-associated Cuban Boa (Chilabothrus angulifer) in "El Abono Cave," Cariblanca, Sancti Spíritus Province. Boas may show high fidelity to sites with abundant and stable food resources such as bat caves. The individual in the photos is the same female that measured $1.245 \mathrm{~m}$ SVL when first marked on 10 April 2013 (left) and $1.345 \mathrm{~m} \mathrm{SVL}$ when recaptured 56 months later (>4.5 years) on 5 December 2017 (right). The total increase during this period was $100 \mathrm{~mm}$, for an average growth rate of $0.06 \mathrm{~mm} /$ day (ca. $2.0 \mathrm{~mm} / \mathrm{month}$ ). Photographs (C) T.M. Rodríguez-Cabrera (left, tripod) and Raimundo López-Silvero (right). 
These results largely coincide with previous observations on other large constrictors (Slip and Shine 1988; Shine and Slip 1990; Harlow and Shine 1992; Shine and Fitzgerald 1996; Luiselli and Angelici 1998; Luiselli et al. 1998, 2001; Shine et al. 1998; Martins and Oliveira 1999; Fearn et al. 2001; Quick et al. 2005; Pizzatto et al. 2009; Reed and Rodda 2009). Other large species of Chilabothrus, especially adult snakes, also seem to follow a similar pattern to that observed in Ch. angulifer (Reagan 1984; Henderson et al. 1987; Wiley 2003; Puente-Rolón et al. 2016; see Henderson and Powell 2009 for a review). A comparable change in diet from mostly native mammals in natural habitats to mostly domestic birds in anthropogenic habitats has been reported in some pythons. Australian Carpet Pythons (Morelia spilota) are large snakes (to $>4.0 \mathrm{~m}, 11 \mathrm{~kg}$ ) that consume a considerable number of domestic and commensal birds and mammals when associated with anthropogenic habitats (Shine and Fitzgerald 1996; Fearn et al. 2001). Shine and Fitzgerald (1996) noted that $89 \%$ of prey items recorded in the diet of M. spilota in a rural area was comprised of commensal and domestic animals. Similarly, in a sample of 97 prey items obtained from 64 pythons associated with urban and suburban habitats, a high proportion consisted of non-native animals, predominantly birds (64\%), followed by mammals (35\%), with reptiles representing only $1 \%$ (Fearn et al. 2001). On the contrary, of 57 prey items identified from gut and fecal contents of Carpet Pythons from a broader geographic context, $49(86 \%)$ were mammals, five $(9 \%)$ were birds, and three (5\%) were reptiles (Slip and Shine 1988). Mammals seem to be the most frequent prey of large constrictors in natural habitats, whereas birds are the most common endothermic prey exploited in human-altered environments. Luiselli et al. (2001) drew similar conclusions from a study of African Rock Pythons (Python sebae).

Desmarest's Hutia (Fig. 8) was the prey species most frequently consumed by $C h$. angulifer in natural habitats. This rodent is the largest native non-volant mammal in Cuba, averaging about $45.0 \mathrm{~cm}$ in body length and $4.0 \mathrm{~kg}$ in weight (Silva et al. 2007; Borroto-Páez 2011b). The two other relatively large species of Cuban hutias (see Silva et al. 2007 for a review) are known prey of Cuban Boas as well, although in considerable smaller numbers (Table 1). Predation by Ch. angulifer on hutias was noticed by the first Europeans arriving in the region. Fernández de Oviedo (1535, officially published in 1851) mentioned snakes as large as 7.6-9.1 $\mathrm{m}$ in length containing 6-7 "guabiniquinax" (= hutias; see Rodríguez-Cabrera et al. 2016a for a review). Despite a lack of details, Oviedo's (1851) comment was the first reference to the feeding habits of Cuban Boas and, for that matter, of any identifiable West Indian snake (Rodríguez-Cabrera et al. 2016a). A number of other authors have listed hutias among the prey of this boa (Appendix 1); for example, P.J. Tolson (in Tolson and Henderson 2006 and Henderson and Powell
2009) noted that the feces of every adult boa examined on the U.S. Naval base at Guantánamo Bay contained hair of Desmarest's Hutias. Our results corroborate previous reports of hutias as prey of Ch. angulifer as well as Oviedo's (1851) description of multiple hutias consumed by a single boa.

In the case of the Cuban Boa preying on an adult Redtailed Hawk, one of the largest living raptors in Cuba (to $1.74 \mathrm{~kg}$ and to $1.41 \mathrm{~m}$ wingspan; Crossley et al. 2013), the means by which the hawk was captured is uncertain. The boa might have approached the roosting bird at night by employing a tactic similar to that used by boas in anthropogenic habitats to prey on domestic fowl. However, an alternative explanation could have been a failed predation attempt by the hawk. The Red-tailed Hawk has been widely documented as a snake predator, including in the West Indies (Guthrie 1932; Fitch et al. 1946; Knight and Erickson 1976; Fitch and Bare 1978; Sherrod 1978; Palmer 1988; Santana and Temple 1988; Global Raptors Information Network 2020). Wenner (2012) reported a case in New Mexico (USA) in which a hawk apparently initiated a predation attempt on a Gopher Snake (Pituophis catenifer, ca. $1.6 \mathrm{~m}$ total length) and instead was captured and constricted by the snake. Similar situations involving Red-tailed Hawks and other raptors, including owls, have been repeatedly observed (Shaw 2017; https://youtube.com). Raptors on occasion may attack snakes that they are unable to subdue. A snake exceeding $2.5 \mathrm{~m} \mathrm{SVL}$, such as the Cuban Boa that consumed the Red-tailed Hawk (P.N. Otero, pers. comm. 2013) certainly does not fall within the range of prey sizes consumed by this raptor (Guthrie 1932; Fitch et al. 1946; Knight and Erickson 1976; Fitch and Bare 1978; Sherrod 1978; Palmer 1988; Santana and Temple 1988; Global Raptors Information Network 2020). However, a small portion of a well camouflaged snake such as the tail might have attracted the hawk's attention, with fatal consequences for the bird. Another boa (ca. $2.6 \mathrm{~m} \mathrm{SVL}$ ) consumed two nestling Turkey Vultures, which it probably found by searching actively. A third boa (ca. $3.0 \mathrm{~m} \mathrm{SVL}$ ) escaped from captivity in the Santa Clara Zoo, entered an aviary containing Caracaras and ate an adult. To the best of our knowledge, these are the first records of snakes preying on raptors in the West Indies and probably among the few cases reported in the world (see Guthrie 1932 for a review). Herrera and Aparicio (2019) reported a Central American Boa Constrictor (Boa imperator; ca. $2.2 \mathrm{~m}$ total length; referred to as B. constrictor, but see Reynolds and Henderson 2018 and references therein) preying on an adult Barn Owl (Tyto alba, referred to as T. furcata; but see Chesser et al. 2019).

Ontogenetic shift in diet.-The frequency of prey types consumed by subadult/small adult and medium-sized adult Cuban Boas differed significantly within and between habitat types. Those results lend support to the hypothesis that an ontogenetic shift in diet occurs. Most medium-sized to large 
boids are relatively small at birth (usually $<500 \mathrm{~mm}$ SVL, $<20$ g) (for reviews see Tolson and Henderson 1993; Pizzato and Marques 2007; Henderson and Powell 2009; Reed and Rodda 2009). Neonatal Ch. angulifer are among the largest within the family (505-646 mm SVL, 80-237 g) (Bloxam and Tonge 1981; Tolson and Henderson 1993; RodríguezCabrera et al. 2015). Only neonatal Boa Constrictors (Boa constrictor) and Green Anacondas (Eunectes murinus) are of comparable sizes (Rivas 2000; Pizzato and Marques 2007; Reed and Rodda 2009). As a consequence, the diets of most neonatal boids are based largely on lizards and other small ectothermic vertebrates before undergoing an ontogenetic shift to endothermic prey (Henderson et al. 1987; Henderson 1993; Pizzatto et al. 2009; Henderson and Pauers 2012; Henderson et al. 2013; Henderson and Powell 2009; YánezMuñoz et al. 2017). The diets of species that have been extensively studied appear to follow a pattern in which juveniles begin to consume endothermic prey as they approach 600 $\mathrm{mm}$ SVL and drop ectothermic prey from their diets after reaching 1.0 m SVL (Henderson et al. 1987; Henderson 1993; Tolson et al. 2007; Pizzatto et al. 2009; Henderson and Powell 2009). The average size of neonatal Ch. angulifer coincides with the size at which other species of boids begin to consume endotherms (Rodríguez-Cabrera et al. 2015). Thus, even though we found support for an ontogenetic shift in the diet in Ch. angulifer, the shift from ectothermic to endothermic prey was not as pronounced as in species of boids with smaller neonates (Henderson et al. 1987; Henderson 1993; Pizzatto et al. 2009; Henderson and Pauers 2012; Henderson et al. 2013; Henderson and Powell 2009; Yánez-Muñoz et al. 2017). Juvenile and even small adult Cuban Boas may consume ectotherms, but they appear to represent only a small portion of their diets. In this review, we included only one case of a subadult/small adult Cuban Boa preying on a juvenile Cuban Iguana (Cyclura nubila) on the U.S. Naval Base at Guantánamo Bay (P.J. Tolson, in litt. 20.iv.2020). Cuban Iguanas are the largest lizard in the West Indies (to $>1.0 \mathrm{~m}$ SVL and $5.5 \mathrm{~kg}$ ) and may occur at high densities in certain areas (Beovides-Casas and Mancina 2006; see Henderson and Powell 2009 for a review). Iguanas certainly represent an important portion in the diet of some $C h$. angulifer populations, including that around Guantánamo Bay (P.J. Tolson, in litt. 22.iv.2020). Due to the large size of this lizard, it might be among the few types of ectothermic prey with a sufficiently high energetic reward for even very large Cuban Boas. Other species of Cyclura have been documented in the diets of Bahamian and Jamaican species of Chilabothrus (see Henderson and Powell 2009 and Reynolds and Gerber 2012 for reviews).

We did find an ontogenetic shift in the diet of Cuban Boas from smaller to larger endothermic prey (Figs. 6 and 12). Our results suggest that boas approaching $2.0 \mathrm{~m} \mathrm{SVL}$ in natural habitats, particularly caves, shift their diet to hutias, rats, and medium-sized to large birds, probably because these prey are more energetically rewarding (Table 1; Figs. 6 and 12; Rodríguez-Cabrera et al. 2015). Consequently, the presence of a very large boa in or around a cave with a large bat colony does not necessarily mean that the boa is feeding on bats (although see foraging strategy below), especially since other larger and easier-to-capture prey such as hutias, rats, and birds can be associated with caves as well (Linares et al. 2009). Using stable isotopes, Puente-Rolón et al. (2016) found no significant differences in the prey types (i.e., bats and rodents) consumed by cave-associated and forest-foraging Puerto Rican Boas. In fact, their results showed that boas in both habitats acquired most of their energy from introduced murid rodents. The situation in Cuban Boas might be similar. Additionally, large boas, especially pregnant females, might exploit bat caves as resting sites to facilitate thermoregulation, and not necessarily as feeding grounds (Rodríguez-Cabrera et al. 2016b; see also Puente-Rolón and Bird-Picó 2004 and Puente-Rolón 2012 for similar observations of Puerto Rican Boas, Ch. inornatus).

The growth rate of cave-associated boas seems to be low compared to other large constrictors (Smith 1999; Madsen and Shine 2000; Reed and Rodda 2009; Rodríguez-Cabrera et al. 2016b). Recaptured boas that were marked as juveniles ( $<700 \mathrm{~mm}$ SVL) showed an average growth rate of $0.5 \mathrm{~mm} /$ day. However, all boas that were marked as mature individuals or approaching sexual maturity $(>1.25 \mathrm{~m} \mathrm{SVL})$, showed an average growth rate of about $0.07 \mathrm{~mm} /$ day (Fig. 18). The growth rates of cave-associated boas with a diet largely based on bats captured on the wing might be low due to energetic constraints (see below). However, Ch. angulifer shows relatively low growth rates even in captivity (Tolson 1992; Tolson and Henderson 1993; Morell et al. 1998; Polo and Moreno 2007). Among large boids, free-ranging Green Anacondas also show relatively low growth rates (Rivas and Corey 2008; Rivas et al. 2016).

Foraging strategy.-We found differences in the frequencies of foraging modes employed by boas in natural habitats and anthropogenic habitats. This lends support to the hypothesis that foraging modes differ between boas in different habitat types. Chilabothrus angulifer relied on both sit-and-wait and active foraging modes in natural habitats, depending on the prey species involved and characteristics of the habitat. Boas in natural habitats foraged almost equally frequently by day and night, whereas predation events in anthropogenic habitats occurred almost exclusively at night, generally before midnight, and the snakes very likely found their prey by searching actively. Also, most if not all the boas found with stomach contents in this type of habitat probably captured their prey using an active foraging strategy. The most frequently taken prey species of $C h$. angulifer in anthropogenic habitats are 
diurnal and aggregate in roosting sites at night or were confined to cages. To access them, the boas necessarily had to search actively for the prey. Also, in anthropogenic habitats the boas are more exposed to human predation during the day. Whether the marked nocturnal activity observed in boas associated with human-altered habitats is a response to the characteristics of the available prey or a recently acquired strategy to avoid human persecution is unknown and deserves further investigation. On only one occasion did a boa capture a domestic chicken by day, and it likely used an ambush strategy (Fig. 16). Similarly, although Carpet Pythons are primarily ambush predators in natural habitats (Slip and Shine 1988; Shine and Fitzgerald 1996; Fearn et al. 2001), Fearn et al. (2001) noted that most Morelia spilota associated with suburban habitats in Australia preyed on domestic animals using an active foraging mode at night. Likewise, African Rock Pythons are primarily diurnal in natural habitats and primarily nocturnal in anthropogenic habitats, with all predation events by Python sebae in suburban habitats in which a time was determined occurring at night (Luiselli et al. 2001). Burmese Pythons (Python bivittatus) introduced in Florida are primarily ambush foragers but may use an active-foraging mode in suburban areas (Reed and Rodda 2009; Reed et al. 2012). Anthropogenic habitats, with their unique structural environments and associated species and threats seem to force large constrictors to adopt a different foraging mode than that most frequently used in natural habitats.

Foraging times of cave-associated Ch. angulifer largely coincided with the exodus of phyllostomid and some mormoopid bats (e.g., Antillean Ghost-faced Bats, Mormoops blainvillei) that leave the caves later in the evening (see Silva 1979 for activity times of bats; H. Vela, pers. comm. 8.v.2020). This is consistent with the proportion of phyllostomid bats (86\%) observed in the diet of Ch. angulifer. When we analyzed the general context of cave-associated species of Chilabothrus (i.e., Ch. angulifer, Ch. inornatus, and Ch. subflavus), we observed a pattern where certain bat groups were better represented than others in the diets of these boas. Of 101 successful predation events by boas on bats, $85 \%$ involved phytophagous phyllostomids (in decreasing order of frequency: i.e., A. jamaicensis $[32.7 \% ; 27-45 \mathrm{~g}]$, E. sezekorni [23.8\%; 13-21 g], P. poeyi [20.8\%; 15-29 g], Leach's Single Leaf Bat, Monophyllus redmani $[3.0 \% ; 8-14 \mathrm{~g}]$, Antillean Fruit-eating Bats, Brachyphylla cavernarum [3.0\%; $35-50 \mathrm{~g}]$, and B. nana [2.0\%; $27-41 \mathrm{~g}]$ ); only a small proportion (5\%) was composed of insectivorous bats (Mormoops blainvillei [6-11 g; Mormoopidae] and Pallas' Mastiff Bats, Molossus molossus [7-15 g; Molossidae]); with unidentified bats accounting for $8 \%$ of those taken (Hardy 1957; Sheplan and Schwartz 1974; Rodríguez and Reagan 1984; RodríguezDurán 1996; Prior and Gibson 1997; Vareschi and Janetzky 1998; Koenig and Schwartz 2003; Dávalos and Erickson
2004; Miersma 2010; Mancina 2011; Rodríguez-Cabrera et al. 2015; Dinets 2017; this paper). Also, in an additional sample of 117 successful bat captures by Ch. inornatus recorded at "Culebrones Cave" in Puerto Rico, most involved one of four species (in decreasing order of frequency: E. sezekorni; $M$. blainvillii; Sooty Mustached Bats, Pteronotus quadridens [3-6 g]; M. redmani, and B. cavernarum) (Puente-Rolón and BirdPicó 2004; A. Puente-Rolón, in litt. 21.v.2020). Insectivorous bats that form large colonies in caves of the region have a relatively low body mass (average ca. $9 \mathrm{~g}$; 3-15 g), large tail membranes, very low wing loading, and a low average aspect ratio, all of which are associated with highly maneuverable flight (Norberg and Rayner 1987; Mancina 2004; Mancina et al. 2012). On the contrary, most West Indian phytophagous phyllostomids are relatively heavy bats (average mass of species in the region ca. $30 \mathrm{~g} ; 8-50 \mathrm{~g}$ ), with reduced tail membranes, high wing loading, and a low aspect ratio, which confer them with limited maneuverability (Norberg and Rayner 1987; Mancina 2004). This suggests that phyllostomids are more vulnerable to predation by snakes while exiting or entering caves than insectivorous bats. In the case of $C h$. angulifer, a more thorough study focused on cave-associated populations might reveal a different composition in the bat species consumed, depending on the relative abundance of the different bat species inhabiting each cave, but we presume phyllostomids will still dominate the diet. In particular, $P h$. poeyi (Fig. 17) and E. sezekorni are the most abundant phyllostomid species in caves where Ch. angulifer forages for bats (Silva 1979). Consistent with our analysis, a compilation by Esbérard and Vrcibradic (2007) showed that more than half of nearly 20 confirmed species of bats taken by Neotropical snakes were phyllostomids. In a sample of 35 bats taken by the colubrid Western Lyre Snake (Trimorphodon biscutatus) at "Los Laguitos Cave" in Chiapas, Mexico, one phyllostomid species (the Lesser Long-nosed Bat, Leptonycteris yerbabuenae) represented $46 \%$ of all prey items, whereas the remaining $54 \%$ was comprised of four insectivorous species (Natalidae, Mormoopidae) (Marínez-Coronel et al. 2009).

Chilabothrus angulifer is the only species in its genus with heat-sensing labial pits at birth (Tolson 1987; Reynolds et al. 2013; Rodríguez-Cabrera et al. 2015). Assuming that they play an important role (infrared detection) when foraging for flying bats in complete darkness is reasonable. However, the foraging behavior of cave-associated $C h$. angulifer very much resembles that reported for other species of Chilabothrus that lack heat-sensing labial pits (Rodríguez and Reagan 1984; Rodríguez-Durán 1996; Prior and Gibson 1997; Vareschi and Janetzky 1998; Koenig and Schwartz 2003; Dávalos and Erickson 2004; Puente-Rolón and Bird-Picó 2004). Chilabothrus inornatus and Ch. subflavus hang from two-thirds to three-fourths of their bodies (>75\%) with the heads slightly elevated and sometimes may adopt a double 
S-shaped striking posture once bats begin to emerge (at least Ch. inornatus also has been observed securing bats in the latter manner; A. Puente-Rolón, in litt. 12.v.2020). Chilabothrus inornatus may even move from side to side while hanging (Rodríguez-Durán, 1996; Puente-Rolón and Bird-Picó 2004). Chilabothrus striatus also has been observed foraging for bats at cave openings on Hispaniola, but detailed studies of its behavior do not exist (J.A. Ottenwalder in Henderson and Powell 2009). In the case of Ch. angulifer, it uses only the anterior third of the body, usually straight but occasionally in a double S-shaped striking posture, either hanging vertically or obliquely down, extended horizontally, or oriented upward (see also Hardy 1957; Mancina 2011), but has never been observed making oscillatory movements with its body. This suggests that the bat-hunting behavior of Puerto Rican Boas, and probably also that of Jamaican boas, is more complex and specialized than that of Cuban Boas.

Snakes are very sensitive to mechanical stimuli (Ford and Burghardt 1993; Lillywhite 2014). The three species of Chilabothrus mentioned above seem to use the suspended portions of their bodies as "tactile antennae," with contact by and collisions with bats serving as triggers for strikes by snakes. The boas we observed did not predict the approach of a flying bat since they never struck unless contacted by a bat, similar to what other authors have described for West Indian boas preying on bats (Rodríguez and Reagan 1984; Rodríguez-Durán 1996; Prior and Gibson 1997; Vareschi and Janetzky 1998; Puente-Rolón and Bird-Picó 2004; Mancina 2011; Dinets 2017). The use of infrared and chemical stimuli by species of Chilabothrus might be more important when actively searching for prey or when employing a sit-and-wait foraging strategy when not hunting for flying bats (e.g., roosting bats, rodents, birds; Silva-Taboada and Koopman 1964). Tactile cues seem more useful when foraging for fast-moving prey such as flying bats (see Ford and Burghardt 1993 for a review on integration of sensory information in snakes), but additional studies are required to corroborate this hypothesis.

Very few of the boas observed preying on bats exceeded $2.0 \mathrm{~m}$ SVL. The 41 boas collected by Hardy (1957) in a cave at Guanayara, near Trinidad, ranged in length from "four to eight feet" (i.e., 1.22-2.44 m total length; ca. 1.1-2.2 m SVL). Berovides and Carbonell (1998) reported a mean SVL of $1.56 \mathrm{~m}$ in 19 individuals measured in "Los Majaes Cave" near Galalón, Pinar del Río Province, with no significant differences between sexes. The estimated total length of nine individuals associated with a sinkhole cave containing a colony of A. jamaicensis at "Desembarco del Granma" National Park ranged from 1.1-2.1 m (ca. 1.0-1.9 m SVL; Dinets 2017). The senior author has observed nearly 150 bat-hunting boas across the Cuban Archipelago and none exceeded $2.0 \mathrm{~m} \mathrm{SVL}$ (mean $1.396 \pm 0.287 \mathrm{~m} \mathrm{SD}, 0.51-1.84, \mathrm{n}=147$ ). We suggest that the cost of foraging for bats becomes too high as the boas approach $2.0 \mathrm{~m} \mathrm{SVL}$, making bats unprofitable prey (see Arnold 1993 for a review). The boas must drop this kind of prey from their diets just before or at the moment the energy gain from them is zero or negative (i.e., the costs of searching, capturing, ingesting, and digesting prey is higher than the energy gain from that particular prey; Arnold 1993) (Fig. 12). As far as we know, the net energy contained in West Indian bats has not been studied, but certainly they constitute relatively small prey (2-87 g) with a considerable area of skin due to wing and tail membranes (Silva 1979). Flying bats seem to represent low-energy or marginal prey, particularly for larger boas that probably incur larger foraging costs than juveniles (Schoener 1971; Arnold 1993; Koenig and Schwartz 2003). We did not quantify successful capture rates of flying bats by Ch. angulifer relative to snake body size, but we have observed many failed capture attempts. Prior and Gibson (1997) recorded $>200$ unsuccessful and no successful strikes during a hunting session (1 h $45 \mathrm{~min}, 1.6-2.5$ attempts/min) of a juvenile Ch. subflavus ( $950 \mathrm{~mm} \mathrm{SVL}, 320 \mathrm{~g}$ ) using a similar foraging strategy. In reference to another type of unprofitable prey (i.e., "hard-to-eat prey"), Feder and Arnold (1982) studied the energy costs involved in staged predation events on Red-cheeked Salamanders (Plethodon jordani) by Western Terrestrial Gartersnakes (Thamnophis elegans). They measured the average energy content of the prey $(\mathrm{ca} .2,000 \mathrm{cal})$, the rate of failed capture attempts (32\%), and the costs involved in the various steps of the predation process (Feder and Arnold 1982; Arnold 1993), concluding that even if only $0.1 \%$ of the capture attempts are successful, salamanders should still be retained in the snake's diet. A similar situation might apply to bats in the diet of Ch. angulifer, at least until they approach $2.0 \mathrm{~m} \mathrm{SVL}$. For example, every individual in a group of nine bat-hunting Cuban Boas studied during an eight-day period in a sinkhole cave succeeded in capturing bats at least twice (maximum four times) during that period (Dinets 2017; in litt. 4.v.2020). Foraging for flying bats should be classified as a special type of sit-and-wait foraging strategy, one in which a considerable amount of time and energy is invested between the phases of encountering and capturing prey (for reviews see Schoener 1971; Arnold 1993). The energetic costs of strikes at flying bats could be equivalent to costs of pursuit in active-foraging strategies (Schoener 1971; Arnold 1993), but additional studies are required to test this assumption. Also, other physical constraints apply. For example, effects of gravity on blood circulation increase as hanging snakes grow larger (Lillywhite and Henderson 1993). The size ranges observed in other species of Chilabothrus that exploit bats as food coincide with our observations (Rodríguez and Reagan 1984; RodríguezDurán 1996; Prior and Gibson 1997; Vareschi and Janetzky 1998; Koenig and Schwartz 2003; Dávalos and Erickson 2004; Puente-Rolón and Bird-Picó 2004). Consequently, the costs of bat hunting seem to be positively correlated with an 
increase in snake size, apparently limiting this resource to boas $<2.0 \mathrm{~m}$ SVL (see also Koenig and Schwartz 2003; PuenteRolón 2012). Exceptions, however, apparently exist. In at least one hot cave with very narrow passages and small openings located north of the Sierra del Rosario in western Cuba, Cuban Boas considerably larger than $2.0 \mathrm{~m} \mathrm{SVL}$ might forage for bats, presumably at a lower energetic cost, by merely opening their mouths in the midst of a dense pack of flying bats exiting the cave (A. Hernández pers. comm. 8.vi.2020; see also Hardy 1957 for relatively large boas associated with a bat cave). Similarly, Angin (2014) observed a Dominica Boa (Boa nebulosa; ca. $3.0 \mathrm{~m}$ total length) using a similar strategy to capture a flying Antillean Fruit-eating Bat at a cave entrance in Dominica.

A common occurrence observed in boas in both natural and human-altered habitats was dropping to the ground, (sometimes from heights $>4 \mathrm{~m}$ ) after capturing relatively large prey (e.g., hutias, adult domestic chickens) in trees. Conversely, relatively small prey (e.g., bats, chicks) captured in trees or from a cave roof were consumed while hanging. Dropping to the ground might reduce energetic costs or facilitate constriction when handling large prey.

Conservation implications.-Estrada (1994) commented that boas surviving habitat loss often acclimatize to life in groves and small forested areas near human houses and rural settlements where they prey on domestic animals like poultry. Our analysis supports that statement. To a certain extent, a high tolerance of human disturbance by $C h$. angulifer could be seen as a positive trait. However, because boas moving into human-altered habitats seem to make no distinction between wild and domestic prey, a move into anthropogenic environments in search of food and shelter increases the likelihood of conflicts between boas and humans. Once a boa arrives on a farm or in a small village, it must undergo a dramatic shift in diet from mostly native species in natural habitats to almost entirely domestic and human-commensal animals. Rural residents have contradictory attitudes toward boas since they are simultaneously beneficial because they prey on introduced murid rodents and harmful because they also prey on domestic animals. However, negative attitudes usually prevail. Interviews of local people in rural areas of Cuba revealed that the first reaction toward a boa in $>90 \%$ of these people is to kill it (T.M. Rodríguez-Cabrera, unpubl. data). In most cases, they argued that the justification was to prevent boas from eating their chickens. Whether domestic animals consumed by $C h$. angulifer in anthropogenic habitats are livestock (i.e., poultry, pigs, goats, sheep) or pets (i.e., dogs, cats, caged birds), the loss of these animals incurs negative consequences that are either economic, emotional, or both. Therefore, that boas become "nuisance" animals that are exterminated without hesitation by most people in rural areas is not surprising (see also Estrada 1994). For example, Barbour and Ramsden
(1919) stated that "The Majá [Ch. angulifer] is very much persecuted by the country folk because of its destruction of domestic fowl, turkeys, and young pigs" (see Appendix I for additional pertinent references). Other large species of Chilabothrus that consume domestic animals also trigger human-wildlife conflicts (see Henderson and Powell 2009 for a review). A number of species of boas and pythons associated with human-altered areas are well known to consume domestic animals, including some of sentimental value such as pet dogs and cats (Shine and Fitzgerald 1996; Murphy and Henderson 1997; Shine et al. 1998; Fearn et al. 2001; Luiselli et al. 2001; Quick et al. 2005; Henderson and Powell 2009; Reed and Rodda 2009).

Ever-increasing habitat loss and ongoing persecution by humans have resulted in Ch. angulifer being listed as Near Threatened on the IUCN Red List of Threatened Species (Day and Tolson 1996). More recently, it was listed in the Red Book of Cuban Vertebrates (Polo and Rodríguez 2012) and included in CITES Appendix II (https://www.cites.org/eng/app/appendices.php). Some national regulations (Ministerio de Justicia 2011) have listed this boa to prevent poaching, but intentional killing remains one of the main threats to this species and is still far from being resolved. Radiotracked Ch. inornatus associated with habitats without concentrated food resources were more likely to move than those associated with foodrich habitats (e.g., bat caves; Puente-Rolón and Bird-Picó 2004). In the case of Ch. angulifer, the combination of habitat loss and decreased sizes of prey populations (e.g., hutias) is increasingly forcing boas into anthropogenic habitats. This species has dominated Cuba's terrestrial ecosystems for millions of years before the first humans arrived in the region just a few thousand years ago (Rodríguez-Cabrera et al. 2016a; Napolitano et al. 2019; Nägele et al. 2020). Those large individuals that we see today preying on domestic animals are merely exploiting the only available food in the remaining accessible habitats.

Considerations for further studies.-This is the first attempt to integrate and analyze the feeding habits and foraging behavior of free-ranging Cuban Boas. The relative importance of various prey taxa in the diet of Ch. angulifer may be biased as a consequence of two main factors: (1) Very small prey items and prey items in very advanced states of digestion can go unnoticed in the stomachs of some snakes, especially large individuals, and (2) smaller snakes are harder to detect (see Reed and Rodda 2009 for a review). Also, we did not assess possible seasonal and regional differences in prey availability relative to its representation in the diets of boas due to a lack of sufficiently large sample sizes from various localities within reasonable periods of time.

Further studies are required to assess local adaptations for exploiting available trophic resources throughout the year 
(e.g., in bat caves) and any possible sex-specific niche partitioning (females may be twice as heavy as males). The use of different techniques such as scat analysis and radiotelemetry to track snakes could reveal new and important information on the ecology and feeding habits of Ch. angulifer (Shine and Fitzgerald 1996; Petersen et al. 2007; Puente-Rolón and Bird-Picó 2004; Wunderle and Mercado 2004; Quick et al. 2005). Also, the use of stable isotopes could provide greater insights into the trophic ecology of this boa and its role in the different ecosystems of the Cuban Archipelago (Rush et al. 2014; Puente-Rolón et al. 2016; Durso and Mullin 2017).

\section{Acknowledgments}

We thank everyone who shared unpublished data (in alphabetic order): Manuel Alonso, Luis F. de Armas, Gerardo Begué, Maikel Cañizares, Maydiel Cañizares, Nelson Capote, Rolando Cardoso, Rubén Chamizo, Alberto Clark, Dennis Denis, Armando Falcón, Osvaldo Fariñas, Ansel Fong, Elier Fonseca, Tomás García, Haydée González, Horacio Grillo, Arturo Hernández, Orestes Hernández, Elsa M. Hiralda, Julio D. León, José L. Linares, Raimundo López-Silvero, Roberto Martínez ("Mil Cumbres" Managed Resource Protected AreaMCPA), Roberto Martínez (Jardín Botánico de Cienfuegos), Mario V. Muñoz, Pedro N. Otero, David Ortiz, Luis B. (“Cuco") Pérez, Rafael A. Pérez, Alberto Puente-Rolón, Rafael Roche, Elsa Rodríguez, Rosa C. Rodríguez, Cándida Sampedro, Rolando Teruel, Peter J. Tolson, Roberto Varela, Leopoldo M. Vasallo, Leosvany Vasallo, Leosveli Vasallo, and Humberto Vela. Some of these and other people also generously assisted us in the field, provided accommodations, and/ or helped during the preparation of the manuscript: Alejandro Abella, C. Sampedro, Francisca ("Pancha") Amador, Aliesky del Río, Rosario ("Charo") Domínguez, T. García and family, Carlos Hernández, J.D. León, Yoana Lisca, Armando R. Longueira, Yaira López, R. López-Silvero, R. Martínez (MCPA), L.B. Pérez, Samuel Reina, Alejandro M. Rodríguez, R.C. Rodríguez, L.M. Vasallo, Leosvany Vasallo, Leosveli Vasallo, and H. Vela. Literature references were provided by Martín Acosta, Seriocha Amaro, Vicente Berovides, R. Chamizo, Luis M. Díaz, A. Fong, Robert W. Henderson, Manuel Iturriaga, Osvaldo Jimenez, Susan E. Koenig, Carlos A. Mancina, Carlos A. Martínez, Rosalina ("Nina") Montes, Lourdes Mugica, Lígia Pizzatto, Robert Powell, A. PuenteRolón, Richard Shine, P.J. Tolson, and Lázaro W. Viñola. Additional information supplementing their pertinent published papers was provided by Rafael Borroto, R. Chamizo, Vladimir Dinets, Esteban Godínez, Veronika Holanova, Jan Hribal, C.A. Mancina, Alcides Sampedro, and P.J. Tolson. Maydiel and Jessica Cañizares helped with English. Photographs were provided by A. Abella, Aslam I. Castellón, A. del Río, H. González, E.M. Hiralda, R. López-Silvero, Carlos A. Pérez, Rafael A. Pérez, and S. Reina. We also thank
R.W. Henderson, P.J. Tolson, and R. Chamizo for their critical reviews that improved the manuscript. The Mohamed bin Zayed Species Conservation Fund (project No. 170515264 to the senior author) provided financial support for some expeditions in central Cuba.

\section{Literature Cited}

Acosta [Cruz], M. and L. Mugica [Valdés]. 2019. A general assessment of Whitecrowned Pigeon (Patagioenas leucocephala) populations in western Cuba. The Journal of Caribbean Ornithology 32: 17-25.

Alberts, A.C., T.D. Grant, G.P. Gerber, K.E. Comer, P.J. Tolson, J.M. Lemm, and D. Boyer. 2001. Critical Reptile Species Management on the U.S. Naval Base, Guantanamo Bay, Cuba. Final Project Report - October, 2001. Agreement No. 62470-00-M-5219. Center for Reproduction of Endangered Species, Zoological Society of San Diego, San Diego, California, USA.

Alfonso Álvarez, E. Morell Savall, R. Díaz Aguiar, R. Carbonell Paneque, F. Morera, and V. Berovides Álvarez. 1998. Epicrates angulifer (Majá de Santa María). In: E. Pérez, E. Osa, Y. Matamoros, and U.S. Seal (eds.), Taller para la Conservación, Análisis y Manejo Planificado de una selección de especies cubanas II. IUCN/SSC Conservation Breeding Specialist Group, Apple Valley, Minnesota, USA.

Alonso, R. and A. Rodríguez [Gómez]. 2003. Insospechados habitantes de las penumbras, pp. 20-29. In: L. Rodríguez[-]Schettino (ed.), Anfibios y Reptiles de Cuba. UPC Print, Vaasa, Finland.

Amaro Valdés, S. 2011. El Majá de Santa María: la mayor boa del Caribe insular. CartaCuba 3: 1-3.

AmphibiaWeb. 2020. University of California, Berkeley, California, USA. <https:// amphibiaweb.org>.

Anderson, M.J., R.N. Gorley, and K.R. Clarke. 2008. PERMANOVA+ for PRIMER: Guide to Software and Statistical Methods. PRIMER-e, Auckland, New Zealand.

Angin, B. 2014. Bat predation by the Dominica Boa (Boa nebulosa). Caribbean Herpetology 51: 1-2.

Anthony, B.P., P. Scott, and A. Antypas. 2010. Sitting on the fence? Policies and practices in managing human-wildlife conflict in Limpopo Province, South Africa. Conservation and Society 8: 225-240.

Arnold, S.J. 1993. Foraging Theory and prey-size-predator-size relationships in snakes, pp. 87-115. In: R.A. Seigel and J.T. Collins (eds.), Snakes: Ecology and Behavior. The Blackburn Press, Caldwell, New Jersey, USA.

Arredondo Antúnez, O. Introducción a los mamíferos extintos, pp. 23-27. In: R. Borroto-Páez and C.A. Mancina (eds.), Mamiferos en Cuba. UPC Print, Vaasa, Finland.

Barbour, T. 1914. A contribution to the zoögeography of the West Indies, with especial reference to amphibians and reptiles. Memoirs of the Museum of Comparative Zoölogy 44: 205-359.

Barbour, T. and C.T. Ramsden. 1919. The herpetology of Cuba. Memoirs of the Museum of Comparative Zoölogy 47: 186-188.

Beaupre, S.J. and C.E. Montgomery. 2007. The meaning and consequences of foraging mode in snakes, pp. 334-367. In: S.M. Reilly, L.D. McBrayer, and D.B. Miles (eds.), Lizard Ecology: The Evolutionary Consequences of Foraging Mode. Cambridge University Press, Cambridge, England.

Beovides-Casas, K. and C.A. Mancina. 2006. Natural history and morphometry of the Cuban Iguana (Cyclura nubila) in Cayo Sijú, Cuba. Animal Biodiversity and Conservation 29: 1-8.

Berovides Álvarez, V. and R. Carbonell Paneque. 1998. Morfometría y abundancia del majá de Santa María Epicrates angulifer (Ophidia, Boidae). In: E. Pérez, E. Osa, Y. Matamoros, and U.S. Seal (eds.), Taller para la Conservación, Análisis y Manejo Planificado de una Selección de Especies Cubanas II. IUCN/SSC Conservation Breeding Specialist Group, Apple Valley, Minnesota, USA.

Berovides Álvarez, V. and A. Comas G[onzález]. 1997a. Densidad y productividad de la jutía conga (Capromys pilorides) en mangles cubanos. Caribbean Journal of Science 33: 121-123.

Berovides Álvarez, V. and A. Comas [González]. 1997b. Abundancia de la jutía conga Capromys pilorides (Rodentia, Capromyidae) en varios hábitats de Cuba. Revista Biología 11: 25-30. 
Bloxam, Q. and S. Tonge. 1981. A comparison of reproduction in three species of Epicrates (Serpentes, Boidae) maintained at the Jersey Wildlife Preservation Trust. Dodo, Journal of the Wildlife Preservation Trust 18: 64-74.

Borroto-Páez, R. 2011a. Los mamíferos invasores o introducidos, pp. 221-241. In: R. Borroto-Páez and C.A. Mancina (eds.), Mamiferos en Cuba. UPC Print, Vaasa, Finland.

Borroto-Páez, R. 2011b. La jutía conga, pp. 73-81. In: R. Borroto-Páez and C.A. Mancina (eds.), Mamiferos en Cuba. UPC Print, Vaasa, Finland.

Borroto-Páez, R. 2013. Nidos y refugios de ratas negras (Rattus rattus) en Cuba (Mammalia, Rodentia). Solenodon 11: 109-119.

Borroto-Páez, R. and C.A. Mancina. 2006. Importancia del mangle rojo (Rizophora [sic] mangle) para la conservación de las jutías (Rodentia: Capromydae), pp. 170-177. In: L. Menéndez Carrera and J.M. Guzmán Menéndez (eds.), Ecosistema de Manglar en el Archipiélago Cubano: Estudios y Experiencias Enfocados a su Gestión. Editorial Academia, La Habana, Cuba.

Borroto-Páez, R., M. Tejeda, F. Lewis, and M. A. Rodríguez. 1990. Fluctuación poblacional de Mus musculus (L) y Rattus rattus $(\mathrm{L})$ en el cultivo de la caña de azúcar. Revista Biología 4: 121-132.

Buide, M.S. 1966. Reptiles de la Península de Hicacos. Poeyana 21: 1-12.

Buide, M.[S.] 1985. Reptiles de Cuba. Editorial Gente Nueva, Ciudad de La Habana, Cuba.

Buide, M.S. 1986. Diccionario de Nombres Vernáculos de Vertebrados Cubanos. Editorial Academia, La Habana, Cuba.

Capote López, R.P., N.E. Ricardo Nápoles, A.V. González Areu, E.E. García Rivera, D. Vilamajó Alberdi, and J. Urbino Rodríguez. 1989. Vegetación actual, X.1.2-3. In: Instituto de Geografía Tropical de la Academia de Ciencias de Cuba and Instituto Cubano de Geodesia y Cartografía (eds.), Nuevo Atlas Nacional de Cuba. Instituto Geográfico Nacional de España, Madrid, Spain.

Chamizo, R., R. Rodríguez, C. Marcos, and E. Godínez. 1983. Aspectos de la reproducción de la Torcaza Cabeciblanca (Columba leucocephala) en cayos Los Indios, Isla de la Juventud. Revista Forestal Baracoa 13: 65-82.

Chamizo Lara, A., L. Rodríguez Schettino, L.V. Moreno García, M. Domínguez Díaz, and L.M. Díaz Beltrán. 2003. Gigantes y enanos, pp. 74-89. In: L. Rodríguez Schettino (ed.), Anfibios y Reptiles de Cuba. UPC Print, Vaasa, Finland.

Chesser, R.T., K. J. Burns, C. Cicero, J.L. Dunn, A.W. Kratter, I.J. Lovette, P.C. Rasmussen, J.V. Remsen, Jr., D.F. Stotz, and K. Winker. 2019. Check-list of North and Middle American Birds. American Ornithological Society, Chicago, Illinois, USA. <http://checklist.americanornithology.org/taxa>.

Clarke, K.R. and Warwick, R.M. 2001. Change in Marine Communities: An Approach to Statistical Analysis and Interpretation. 2nd Edition, PRIMER-e, Ltd., Auckland, New Zealand.

Comas González, A. and V. Berovides Álvarez. 1990. Densidad de la jutía conga (Capromys pilorides) en cayos del grupo insular Jardines de la Reina, Cuba. Revista Biología 4: 15-20.

Comas González, A., G. Cepero, and V. Berovides Álvarez. 1989. Densidad de la jutía conga (Capromys pilorides) (Rodentia: Capromyidae) en el área protegida Sierra del Chorrillo, Camagüey. Ciencias Biológicas 21/22: 115-129.

Comas González, A., F. Rosales Zequeira, R. González Brito, and U. Peláez Martínez. 1994. Ecología trófica de la jutía conga Capromys pilorides (Rodentia: Capromydae), en el área protegida Sierra del Chorrillo; Camagüey, Cuba. Ciencias Biológicas 8: 75-81.

Conover, M.R. 2001. Resolving Human-Wildlife Conflicts: The Science of Wildlife Damage Management. CRC Press, Boca Raton, Florida, USA.

Cox, N.J. 2008. Stata tip 59: Plotting on any transformed scale. Stata Journal 8 : $142-145$.

Crossley, R., H. Liguori, and B. Sullivan. 2013. The Crossley ID Guide: Raptors. Princeton University Press, Princeton, New Jersey, USA.

Cruz, J. de la. 1992. Bioecología de las grutas de calor. Mundos Subterráneos 3: 7-21.

Daniel, J.C. 2002. The Book of Indian Reptiles and Amphibians. Bombay Natural History Society, Oxford University Press, Mumbai, India.

Dávalos, L.M. and R. Eriksson. 2004. Epicrates subflavus. Foraging behavior. Herpetological Review 35: 66.

Day, M. and P.[J.] Tolson. 1996. Epicrates angulifer. The IUCN Red List of Threatened Species 1996: e.T7815A12852846.

Decker, D.J., T.B. Lauber, and W.F. Siemer. 2002. Human-Wildlife Conflict Management. A Practitioners' Guide. Northeast WDM Cooperative, Ithaca,
New York, USA.

del Risco Rodríguez, E. 1989. Vegetación Original, X.1.4. In: Instituto de Geografía Tropical de la Academia de Ciencias de Cuba and Instituto Cubano de Geodesia y Cartografía (eds.), Nuevo Atlas Nacional de Cuba. Instituto Geográfico Nacional de España, Madrid, Spain.

del Risco Rodríguez, E. 1995. Los Bosques de Cuba: Su Historia y Características. Editorial Científico-Técnica, La Habana, Cuba.

Denis Ávila, D. 2001. Dinámica metapoblacional en las colonias de garzas (Aves: Ardeidae) de la ciénaga de Biramas, Cuba. Journal of Caribbean Ornithology 16: $35-44$.

Denis Ávila, D. 2002. Ecología reproductive de siete especies de garzas (Aves: Ardeidae) en la Ciénaga de Biramas, Cuba. Unpublished Ph.D. Thesis, Universidad de La Habana, La Habana, Cuba.

Denis [Ávila], D. 2006a. Humedales en Cuba, pp. 8-25. In: L. Mugica Valdés, D. Denis Ávila, M. Acosta Cruz, A. Jiménez Reyes, and A. Rodríguez Suárez (eds.), Aves Acuáticas en los Humedales de Cuba. Editorial Científico-Técnica, La Habana, Cuba.

Denis [Ávila], D. 2006b. Aves en los manglares: la complejidad de su reproducción, pp. 66-93. In: L. Mugica Valdés, D. Denis Ávila, M. Acosta Cruz, A. Jiménez Reyes, and A. Rodríguez Suárez (eds.), Aves Acuáticas en los Humedales de Cuba. Editorial Científico-Técnica, La Habana, Cuba.

Denis [Ávila], D., A. Rodríguez, P. Rodríguez, and A. Jiménez. 2003. Reproducción de la Garza Ganadera (Bubulcus ibis) en la en la Ciénaga de Biramas, Cuba. Journal of Caribbean Ornithology 16: 45-54.

Dinets, V. 2017. Coordinated hunting by Cuban boas. Animal Behavior and Cognition 4: 24-29.

Durso, A.M. and S.J. Mullin. 2017. Ontogenetic shifts in the diet of plains hog-nosed snakes (Heterodon nasicus) revealed by stable isotope analysis. Zoology 120: 83-91.

Emmons, I.D., E.M. Nowak, and K.K. Lauger. 2016. Prey availability and foraging events of the Northern Mexican Gartersnake (Thamnophis eques megalops) in north-central Arizona. Herpetological Review 47: 555-561.

Esbérard, C.E. and D. Vrcibradic. 2007. Snakes preying on bats: new records from Brazil and a review of recorded cases in the Neotropical Region. Revista Brasileira de Zoología 24: 848-853.

Estrada, A.R. 1994. Herpetofauna de la Cuenca Banao-Higuanojo, Sancti Spíritus, Cuba. Revista de la Academia Colombiana de Ciencias 19: 353-360.

Estrada, A.R. 2012. The Cuban Archipelago, pp. 113-125. In: R. Powell and R.W. Henderson (eds.), Island lists of West Indian amphibians and reptiles. Bulletin of the Florida Museum of Natural History 51: 85-166.

Estrada, A., R. Coates-Estrada, and D.A. Meritt. 1997. Anthropogenic landscape changes and avian diversity at Los Tuxtlas, Mexico. Biodiversity \& Conservation 6: 19-43.

Fearn, S., B. Robinson, J. Sambono, and R. Shine. 2001. Pythons in the pergola: the ecology of 'nuisance' carpet pythons (Morelia spilota) from suburban habitats in south-eastern Queensland. Wildlife Research 28: 573-579.

Feder, M.E. and S.J. Arnold. 1982. Anaerobic metabolism and behavior during predatory encounters between snakes (Thamnophis elegans) and salamanders (Plethodon jordani). Oecologia 53: 93-97.

Fernández de Oviedo y Valdés, G. 1851. De las serpientes ó culebras de la isla de Cuba ó Fernandina, Cap. V., pp. 500-501. In: J. Amador de Los Ríos (ed.), Historia General y Natural de Las Indias, Islas y Tierra-Firme del Mar Océano. Primera parte, Tomo I, Imprenta de la Real Academia de la Historia, Madrid, Spain (printed in 1535).

Ferreto Fiorillo, B. and D. Sifuentes Batista. 2019. Predation on gray tinamou eggs (Tinamus tao, Tinamiformes: Tinamidae) by a rainbow boa (Epicrates cenchria, Serpentes: Boidae). Herpetology Notes 12: 79-81.

Fitch, H.S. and R.O. Bare. 1978. A field study of the Red-tailed Hawk in eastern Texas. Transactions of the Kansas Academy of Science 81: 1-13.

Fitch, H.S., F. Swenson, and D.F. Tillotson. 1946. Behavior and food habits of the Red-tailed Hawk. The Condor 48: 205-237.

Fong G., A., D. Maceira F., W.S. Alverson, and T. Wachter (eds.). 2005. Cuba: Parque Nacional "Alejandro de Humboldt." Rapid Biological Inventories Report 14. The Field Museum, Chicago, Illinois, USA.

Ford, N.B. and G.M. Burghardt. 1993. Perceptual mechanisms and the behavioral ecology of snakes, pp. 117-164. In: R.A. Seigel and J.T. Collins (eds.), Snakes: Ecology and Behavior. The Blackburn Press, Caldwell, New Jersey, USA.

Forsman, A. 1996. Body size and net energy gain in gape-limited predators: a model. Journal of Herpetology 30: 307-319. 
Fredriksson, G.M. 2005. Predation on sun bears by reticulated python in east Kalimantan, Indonesian Borneo. The Raffles Bulletin of Zoology 53: 165-168.

Funes Monzote, R. 2004. "El asiento de su riqueza”. Los bosques y la ocupación del Este de Cuba por el azúcar, 1898-1926. Anuario Instituto de Estudio Histórico Sociales 19: 231-253.

Gamage, S.N., D.K. Weerakoon, and Gunawardena. 2011. Current status of vertebrate diversity in anthropogenic and natural ecosystems in south-western Sri Lanka. Journal of the National Science Foundation of Sri Lanka 39: 383-389.

Global Raptors Information Network. 2020. Species account: Red-tailed Hawk Buteo jamaicensis <https://www.globalraptors.org>.

Godínez, E. 1993. Situación de las Poblaciones de Columba leucocephala (Aves: Columbidae) en Cuba entre 1979 y 1987. Editorial Academia, La Habana, Cuba.

Godínez, E. and L. Vinola. 1988. Comportamiento reproductivo de una colonia de nidificación de Columba leucocephala en Jagüey Grande, Matanzas. Revista Forestal Baracoa 18: 95-102.

Godínez, E., M. Gómez, J.A. Puentes, and S. Vargas. 1987. Características reproductivas de Columba leucocephala en la Península de Guanahacabibes, Cuba. Poeyana 340: 1-8.

Gosse, P.H. 1851. A Naturalist's Sojourn in Jamaica. Longman, Brown, Green \& Longmans, London, England.

Greshko, M. 2017. Watch first-ever video of python swallowing hyena. <http:// news.nationalgeographic.com/2017/03/snakes-pythons-africa-hyena-kill>.

Gundlach, J.C. 1875. Catálogo de los reptiles cubanos. Anales de la Sociedad Española de Historia Natural 4: 347-368.

Gundlach, J.C. 1880. Contribución á la Erpetología Cubana. Imprenta de G. Montiel y Ca, La Habana, Cuba.

Guthrie, J.E. 1932. Snakes versus birds; birds versus snakes. The Wilson Bulletin 44: 88-113.

Gutiérrez-Domech, R. and M. Rivero-Glean. 1997. Minigeografía de Cuba. Editorial Científico-Técnica, La Habana, Cuba.

Hampton, P.M. 2014. Allometry of skull morphology, gape size and ingestion performance in the banded watersnake (Nerodia fasciata) feeding on two types of prey. The Journal of Experimental Biology 217: 472-478

Hardy, J.D., Jr. 1957. Bat predation by the Cuban boa (Epicrates angulifer). Copeia 2: $151-152$.

Hardy, J.D., Jr. 1963. Biology of some Cuban cave fauna (Abstract). National Speleological Society News 21: 159-160.

Harlow, P. and R. Shine. 1992. Food habits and reproductive biology of the Pacific Island Boas (Candoia). Journal of Herpetology 26: 60-66.

Hedges, S.B., R. Powell, R.W. Henderson, S. Hanson, and J.C. Murphy. 2019. Definition of the Caribbean Islands biogeographic region, with checklist and recommendations for standardized common names of amphibians and reptiles. Caribbean Herpetology 67: 1-53.

Henderson, R.W. 1993. Foraging and diet in West Indian Corallus enydris (Serpentes: Boidae). Journal of Herpetology 27: 24-28.

Henderson, R.W. and M.J. Pauers. 2012. On the diets of Neotropical treeboas (Squamata: Boidae: Corallus). South American Journal of Herpetology 7: 172-180.

Henderson, R.W. and R. Powell. 2009. Natural History of West Indian Amphibians and Reptiles. University Press of Florida, Gainesville, Florida, USA.

Henderson, R.W., T.A. Noeske-Hallin, J.A. Ottenwalder, and A. Schwartz. 1987. On the diet of the boa Epicrates striatus on Hispaniola, with notes on E. fordi and E. gracilis. Amphibia-Reptilia 8: 251-258.

Henderson, R.W., M.J. Pauers, and T.J. Colston. 2013. On the congruence of morphology, trophic ecology, and phylogeny in Neotropical treeboas (Squamata: Boidae: Corallus). Biological Journal of the Linnean Society 109: 466-475.

Hernandez Martínez, F.R. and O. Pimentel Pimentel. 2005. Enfermedades, parásitos y depredadores de la jutía conga (Capromys pilorides Say) en el macizo forestal central de la cordillera de Guaniguanico. Revista Electrónica de Veterinaria REDVET 6: 7 pp. (not numbered).

Herrera R., J.M. and K. Aparicio U. 2019. Reporte de un ataque de Boa constrictor (Serpentes: Boidae) a un individuo de Tyto furcata (Aves: Tytonidae) en Pacora, Panamá. Huitzil, Revista Mexicana de Ornitología 20: e-519.

Holanova, V. and J. Hribal, 2004. Dos anolis cubanos: Anolis bartschi y Anolis lucius. Reptilia 47: 62-68.

Huey, R.B. and E.R. Pianka. 1981. Ecological consequences of foraging mode. Ecology 62: 991-999.

Hurlbert, S.H. 1978. The measurement of niche overlap and some relatives. Ecology
59: 67-77.

IUCN (International Union for Conservation of Nature and Natural Resources). 2020. The IUCN Red List of Threatened Species. <https://www.iucnredlist.org>.

Jiménez, A., I. García-Lau, A. González, L. Mugica, and M. Acosta. 2014. Valores de masa corporal de 183 espcies de aves cubanas. Revista Cubana de Ciencias Biológicas 3: 22-42.

Koenig, S.E. and M. Schwartz. 2003. Epicrates subflavus. Diet. Herpetological Review 34: 374-375.

Koenig, S.E., J.M. Wunderle Jr, and E.C. Enkerlin-Hoeflich. 2007. Vines and canopy contact: a route for snake predation on parrot nests. Bird Conservation International 17: 79-91.

Knight, R.L. and A.W. Erickson. 1976. High incidence of snakes in the diet of nesting Red-tailed Hawks. Journal of Raptor Research 10: 108-111.

Krebs, C.J. 1998. Ecological Methodology. Second Edition. Addison Wesley Longman, Menlo Park, California.

Legón Boada, D. 1998. El almiquí, Solenodon cubanus Peters, 1861. Torreia (Nueva Serie) 43: 3-13.

Levins, R. 1968. Evolution in Changing Environments: Some Theoretical Explorations. Princeton University Press, Princeton, New Jersey, USA.

Lillywhite, H.B. 2014. How Snakes Work. Structure, Function and Behavior of the World's Snakes. Oxford University Press, New York, New York, USA.

Lillywhite, H.W. and R.W. Henderson. 1993. Behavioral and functional ecology of arboreal snakes, pp. 1-48. In: R.A. Siegel and J.T. Collins (eds.), Snakes: Ecology and Behavior. McGraw-Hill, New York, New York, USA.

Linares Rodríguez, J.L., V. Berovides Álvarez, J.A. Camejo Lamas, L. Márquez Llauger, A. Rojas Valdez, and O. Borrego Fernández. 2011. Estudio de las características del hábitat, distribución geográfica y uso de la especie majá de Santa María (Epicrates angulifer) en la Reserva de La Biosfera Península de Guanahacabibes. Cubazoo 23: 27-32.

Lind, A.J. and H.H. Welsh Jr. 1994. Ontogenetic changes in foraging behavior and habitat use by the Oregon garter snake, Thamnophis atratus hydrophilus. Animal Behavior 48: 1261-1273.

Luiselli, L. and G. Amori. 2016. Chapter 8: Diet, pp. 97-109. In: C. Kenneth Dodd, Jr. (ed.), Reptile Ecology and Conservation: A Handbook of Techniques. Oxford University Press, London, England.

Luiselli, L. and F.M. Angelici. 1998. Sexual size dimorphism and natural history traits are correlated with intersexual dietary divergence in royal pythons (Python regius) from the rainforests of southeastern Nigeria. Italian Journal of Zoology 65: 183-185.

Luiselli, L., G.C. Akani, and D. Capizzi. 1998. Food resource partitioning of a community of snakes in a swamp rainforest of south-eastern Nigeria. Journal of Zoology (London) 246: 125-133.

Luiselli, L., F.M. Angelici, and G.C. Akani. 2001. Food habits of Python sebae in suburban and natural habitats. African Journal of Ecology 39: 116-118.

Madsen, T. and R. Shine. 2000. Silver spoons and snake body sizes: prey availability early in life influences long-term growth rates of free-ranging pythons. Journal of Animal Ecology 69: 952-958.

Mammal Diversity Database. 2020. American Society of Mammalogists. <http:// mammaldiversity.org>.

Mancina, C.A. 2004. Bat community structure in an evergreen forest in western Cuba. Poeyana 491: 8-12.

Mancina, C.A. 2011. Introducción a los murciélagos, pp. 122-133. In: R. BorrotoPáez and C.A. Mancina (eds.), Mamiferos en Cuba. UPC Print, Vaasa, Finland.

Mancina, C.A. and A. Llanes Sosa. 1997. Indicios de depredación de huevos de Hirundo fulva (Passeriformes: Hirundinidae) por Epicrates angulifer (Serpentes: Boidae). El Pitirre 10: 95-96.

Mancina, C.A., L. García-Rivera, and B.W. Miller. 2012. Wing morphology, echolocation, and resource partitioning in syntopic Cuban mormoopid bats. Journal of Mammalogy 93: 1308-1317.

Manral, U., S. Sengupta, S.A. Hussain, S. Rana, and R. Badola. 2016. Human wildlife conflict in India: a review of economic implication of loss and preventive measures. Indian Forester 142: 928-940.

Marichal Arbona, E. 2016. El majá de Santa María, Chilabothrus angulifer (Squamata: Boidae), en el Archipiélago Jardines de la Reina: nuevo registro de distribución. Poeyana 503: 64-65.

Marínez-Coronel, M., X. Morales-Medina, and C. Müdespacher-Ziehl. 2009. Depredadores de murciélagos en la cueva de los Laguitos, Chiapas, México. 
Revista Mexicana de Mastozoología 13: 82-91.

Martins, M. and M.E. Oliveira. 1999. Natural history of snakes in forests of the Manaus region, Central Amazonia, Brazil. Herpetological Natural History 6: $78-150$.

Meeks, M.K. 2018. Herpetologist dedicated to Cuban Boa research at Naval Station Guantánamo Bay. Navy News Service, Story Number: NNS18051118. <https://www.navy.mil/submit/display.asp?story_id=105557>.

Miersma, E.E. 2010. Movements, activity range, habitat use, and conservation of the Jamaican (Yellow) Boa, Epicrates subflavus. Unpublished M.Sc. Thesis, The University of Montana, Missoula, Montana, USA.

Miller, G.S. Jr. 1904. Notes on the bats collected by William Palmer in Cuba. Procceedings of the U.S. National Museum 27: 337-348.

Ministerio de Justicia. 2011. Resolución No. 160. Regulaciones para el control y la protección de especies de especial significación para la diversidad biológica en el país. Gaceta Oficial de la República de Cuba 26: 723-745.

Monroy-Vilchis, O., O. Sánchez, and V. Urios. 2011. Consumption of an adult Puma yagouaroundi (Felidae) by the snake Boa constrictor (Boidae) in Central México. Revista Mexicana de Biodiversidad 82: 319-321.

Morell Savall, E., R. Díaz Aguiar, and O. Alfonso Álvarez. 1998. El majá de Santa María (Epicrates angulifer): la boa de la mayor de las Antillas. Flora y Fauna 1: 40-42.

Mullin, S.J. and R.J. Cooper. 2000. The foraging ecology of the gray rat snake (Elaphe obsolete spiloides). II. Influence of habitat structural complexity when searching for arboreal avian prey. Amphibia-Reptilia 21: 211-222.

Murphy, J.C. and Henderson, R.W. 1997. Tales of Giant Snakes: A Natural History of Anacondas and Pythons. Krieger Publishing Co., Malabar, Florida, USA.

Mushinsky, H.R. 1987. Foraging ecology, pp. 302-334. In: R.A. Seigel, J.T. Collins, and S.S. Novak (eds.), Snakes: Ecology and Evolutionary Biology. MacMillan, New York, New York, USA.

Nägele, K., C. Posth, M.I. Orbegozo, Y. Chinique de Armas, S.T. Hernández Godoy, U.M. González Herrera, M.A. Nieves-Colón, M. SandovalVelasco, D. Mylopotamitaki, R. Radzeviciute, J. Laffoon, W.J. Pestle, J. Ramos-Madrigal, T.C. Lamnidis, W.C. Schaffer, R.S. Carr, J.S. Day, C. Arredondo Antúnez, A. Rangel Rivero, A.J. Martínez-Fuentes, E. CrespoTorres, I. Roksandic, A.C. Stone, C. Lalueza-Fox, M. Hoogland, M. Roksandic, C.L. Hofman, J. Krause, and H. Schroeder. 2020. Genomic insights into the early peopling of the Caribbean. Science DOI: 10.1126/ science.aba8697.

Napolitano, M.F., R.J. DiNapoli, J.H. Stone, M.J. Levin, N.P. Jew, B.G. Lane, J.T. O'Connor, and S.M. Fitzpatrick. 2019. Reevaluating human colonization of the Caribbean using chronometric hygiene and Bayesian modeling. Science Advances 5: eaar7806.

Navarro Pacheco, N. 2020. Annotated Checklist of the Birds of Cuba. Edition No. 3. Ediciones Nuevos Mundos, St. Augustine, Florida, USA.

Norberg, U.M. and J.M.V. Rayner. 1987. Ecological morphology and flight in bats (Mammalia; Chiroptera): wing adaptations, flight performance, foraging strategy and echolocation. Philosophical Transactions of the Royal Society of London. Series B, Biological Sciences 316: 335-427.

Ottenwalder, J.A. 1980. Epicrates striatus como predador de aves. Naturalista Postal 21: $1-2$.

Palmer, R.S. 1988. Handbook of North American Birds. Yale University Press, New Haven, Connecticut, USA.

Pearson, D., R. Shine, and A. Williams. 2005. Spatial ecology of a threatened python (Morelia spilota imbricata) and the effects of anthropogenic habitat change. Austral Ecology 30: 261-274.

Petersen, C., F. Burns, and P.[J.] Tolson. 2007. Toledo Zoo and Navy partner to study Cuban boa: researchers use GIS and other technology to collect biological data. Currents Winter 2007: 46-49.

Petersen, C., P.JJ.] Tolson, and J. Jackson. 2015. Cuban Boa helps to maintain ecosystem balance at Guantánamo Bay. Currents Summer 2015: 38-41.

Pizzatto, L. and O.A.V. Marques. 2007. Reproductive ecology of boine snakes with emphasis on Brazilian species and a comparison to pythons. South American Journal of Herpetology 2: 107-122

Pizzatto, L., O.A.V. Marques, and K. Facure. 2009. Food habits of Brazilian boid snakes: overview and new data, with special reference to Corallus hortulanus. Amphibia-Reptilia 30: 533-544.

Poey, F. 1866. Repertorio Físico-Natural de la Isla de Cuba. Tomo II. Imprenta de la viuda de Barcina y Comp., La Habana, Cuba.
Polo Leal, J. L. and L.V. Moreno [García]. 2007. Reproducción y cría del majá de Santa María la boa de Cuba Epicrates angulifer (Bibron, 1843) en el Parque Zoológico Nacional de Cuba. Cubazoo 17: 33-38.

Polo Leal, J.L. and T.M. Rodríguez[-]Cabrera. 2012. Epicrates angulifer Cocteau y Bibron, 1843, pp. 160-164. In: H. González Alonso, L. Rodríguez Schettino, A. Rodríguez [Gómez], C.A. Mancina, and I. Ramos García (eds.), Libro Rojo de los Vertebrados de Cuba. Editorial Academia, La Habana, Cuba.

Prior, K.A. and R.C. Gibson. 1997. Observations on the foraging behavior of the Jamaican Boa, Epicrates subflavus. Herpetological Review 28: 72-73.

Puente-Rolón, A.R. 2012. Reproductive Ecology, Fitness and Management of the Puerto Rican Boa (Epicrates inornatus, Boidae). Unpublished Ph.D. Thesis, University of Puerto Rico, Río Piedras, Puerto Rico.

Puente-Rolón, A.R. and F.J. Bird-Picó. 2004. Foraging behavior, home range, movements and activity patterns of Epicrates inornatus (Boidae) at Mata de Plátano Reserve in Arecibo, Puerto Rico. Caribbean Journal of Science 40: 343-352.

Puente-Rolón, A.R., S.I. Vega-Castillo, L. Stemberg, and E. Cuevas. 2016. Diet comparison of free-ranging and cave-associated Puerto Rican Boas, Chilabothrus inornatus (Reinhardt, 1843) (Reptilia: Boidae), using stable carbon and nitrogen isotopes. Life: The Excitement of Biology 4: 88-99.

Quick, J.S., H.K. Reinert, E.R. de Cuba, and R.A. Odum. 2005. Recent occurrence and dietary habits of Boa constrictor on Aruba, Dutch West Indies. Journal of Herpetology 39: 304-307.

R Core Team. 2018. R: A language and environment for statistical computing. R Foundation for Statistical Computing, Vienna, Austria. <http://www.Rproject.org>.

Rams, A., R.M. Abreu, and J. de la Cruz. 1989. Almiquí (Solenodon cubanus) depredado por perros jíbaros (Canis familiaris). Garciana 21: 1-2.

Reagan, D.P. 1984. Ecology of the Puerto Rican Boa (Epicrates inornatus) in the Luquillo Mountains of Puerto Rico. Caribbean Journal of Science 20: 119127.

Reed, R.N. and G.H. Rodda. 2009. Giant constrictors: Biological and management profiles and an establishment risk assessment for nine large species of pythons, anacondas, and the Boa Constrictor. U.S. Geological Survey OpenFile Report 2009-1202, Reston, Virginia, USA.

Reed, R.N., J.D. Willson, G.H. Rodda, and M.E. Dorcas. 2012. Ecological correlates of invasion impact for Burmese pythons in Florida. Integrative Zoology 7: $254-270$

Regalado Ruiz, P. 1981. Especies llamadas dañinas. Juventud Técnica 162: 28-33.

Reynolds, R.G. and G.P. Gerber. 2012. Ecology and conservation of the Turks Island Boa (Epicrates chrysogaster chrysogaster: Squamata: Boidae) on Big Ambergris Cay. Journal of Herpetology 46: 578-586.

Reynolds, R.G. and R.W. Henderson. 2018. Boas of the world (Superfamily Booidae): A checklist with systematic, taxonomic, and conservation assessments. Bulletin of the Museum of Comparative Zoology 162: 1-58.

Reynolds, R.G., M.L. Niemiller, S.B. Hedges, A. Dornburg, A.R. Puente-Rolón, and L.J. Revell. 2013. Molecular phylogeny and historical biogeography of West Indian boid snakes (Chilabothrus). Molecular Phylogenetics and Evolution 68: 461-470.

Rivas, J.A. 2000. Life History of the Green Anaconda (Eunectes murinus), with Emphasis on its Reproductive Biology. Unpublished Ph.D. Thesis, The University of Tennessee, Knoxville, Tennessee, USA.

Rivas, J.A. and S.J. Corey. 2008. Eunectes murinus (Green Anaconda). Longevity. Herpetological Review 39: 469.

Rivas, J.A., R.A. Ascanio, and M.D.C. Muñoz. 2008. What is the length of a snake. Contemporary Herpetology 2008: 1-3.

Rivas, J.A., C.R. Molina, S.J. Corey, and G.M. Burghardt. 2016. Natural history of neonatal green anacondas (Eunectes murinus): A chip off the old block. Copeia 104: 402-410.

Rivero, J.A. 1978. Los Anfibios y Reptiles de Puerto Rico. The Amphibians and Reptiles of Puerto Rico. Editorial Universitaria, University of Puerto Rico, Rio Piedras, Puerto Rico.

Rodríguez, G. and D.P. Reagan. 1984. Bat predation by the Puerto Rican Boa (Epicrates inornatus). Copeia 1984: 219-220.

Rodríguez-Cabrera, T.M., J. Torres [López], and R. Marrero. 2015. At the lower size limit of snakes preying on bats in the West Indies: The Cuban Boa, Chilabothrus angulifer (Boidae). Reptiles \& Amphibians 22: 8-15.

Rodríguez-Cabrera, T.M., R. Marrero, and J. Torres [López]. 2016a. An over- 
view of the past, present and future of the Cuban boa, Chilabothrus angulifer (Squamata: Boidae): A top terrestrial predator on an oceanic island. Reptiles \& Amphibians 23: 152-168.

Rodríguez-Cabrera, T.M., J. Torres López, R. Marrero, E. Morell Savall, and A. Sanz Ochotorena. 2016b. Sexual maturation in free-ranging Chilabothrus angulifer (Serpentes: Boidae). Phyllomedusa 15: 163-174.

Rodríguez-Durán, A. 1996. Foraging ecology of the Puerto Rican Boa (Epicrates inornatus): Bat predation, carrion feeding and piracy. Journal of Herpetology 30: $533-536$.

Rodríguez Ferrer, M. 1876. Naturaleza y Civilización de la Grandiosa Isla de Cuba, Parte Primera: Naturaleza. Imprenta de J. Noguera a cargo de M. Martínez, Madrid, Spain.

Rodríguez-Robles, J.A., C.J. Bell, and H.W. Greene 1999. Gape size and evolution of diet in snakes: feeding ecology of erycine boas. Journal of Zoology (London) 248: 49-58.

Rodríguez Schettino, L. and A. Rodríguez Gómez. 2003. Especies en peligro y su conservación, pp. 156-161. In: L. Rodríguez Schettino (ed.), Anfibios y Reptiles de Cuba. UPC Print, Vaasa, Finland.

Rodríguez Schettino, L., V. Rivalta González, and E. Pérez Rodríguez. 2010. Distribución regional y altitudinal de los reptiles de Cuba. Poeyana 498: 11-20.

Rodríguez Schettino, L., C.A. Mancina, and V. Rivalta González. 2013. Reptiles of Cuba: Checklist and geographic distribution. Smithsonian Herpetological Information Service 144: 1-96.

Rodríguez-S[chettino]., L., V. Rivalta-G[onzález]., and A. González-C. 2014. Colección herpetológica del Instituto de Ecología y Sistemática, La Habana, Cuba. Familia Dipsadidae, géneros Arrhyton y Cubophis; familia Boidae, género Chilabothrus. Revista Colombiana de Ciencia Animal 6: 14-37.

Rush, S.A., K. Sash, J. Carroll, B. Palmer, and A.T. Fisk. 2014. Feeding ecology of the snake community of the Red Hills region relative to management for Northern Bobwhite: assessing the diet of snakes using stable isotopes. Copeia 2014: 288-296.

Sampedro Marín, A. 1998. Adaptaciones Morfométricas y Conductuales de Trachemys decussata decussata (Chelonia: Emydidae). Unpublished Ph.D. Thesis, Universidad de La Habana, La Habana, Cuba.

Sampedro Marín, A. and L. Montañez Huguez. 1989. Estrategia Reproductiva de la Jicotea Cubana (Pseudemys decussata) en la Ciénaga de Zapata. Editorial Academia, La Habana.

Santana, E.C. and S.A. Temple. 1988. Breeding biology and diet of Red-tailed Hawks in Puerto Rico. Biotropica 20: 151-160.

Schoener, T.W. 1971. Theory of feeding strategies. Annual Review of Ecology and Systematics 2: 369-404.

Schwartz, A. and L.H. Ogren.1956. A collection of reptiles and amphibians from Cuba, with the descriptions of two new forms. Herpetologica 12: 91-110.

Schwartz, A. and R.W. Henderson. 1991. Amphibians and Reptiles of the West Indies: Descriptions, Distributions, and Natural History. University of Florida Press, Gainesville, Florida, USA.

Secor, S.M. 1995. Ecological aspects of foraging mode for the snakes Crotalus cerastes and Masticophis flagellum. Herpetological Monographs 9: 169-186.

Segovia Vega, Y., A.E. Reyes Vázquez, and A. Fong G. 2013. Epicrates angulifer. Diet. Herpetological Review 44: 153-154.

Shaw, E. 2017. 'Great horned owl vs gopher snake' produces a surprising victor (video). Earth Touch News Network. <https://www.earthtouchnews.com/ natural-world/predator-vs-prey/great-horned-owl-vs-gopher-snake-producesa-surprising-victor-video $>$.

Sheplan, B.R. and A. Schwartz. 1974. Hispaniolan boas of the genus Epicrates (Serpentes, Boidae) and their Antillean relationships. Annals of Carnegie Museum 45: 57-143.

Sherrod, S.K. 1978. Diets of North American Falconiformes. Raptor Research 12: 49-121.

Shine, R. 1991. Why do larger snakes eat larger prey items? Functional Ecology 5: 493-502.

Shine, R. and M. Fitzgerald. 1996. Large snakes in a mosaic rural landscape: the ecology of carpet pythons, Morelia spilota (Serpentes: Pythonidae), in coastal eastern Australia. Biological Conservation 76: 113-122.

Shine, R. and D.J. Slip. 1990. Biological aspects of the adaptive radiation of Australasian pythons (Serpentes: Boidae). Herpetologica 46: 283-290.

Shine, R., P.S. Harlow, J.S. Keogh, and Boeadi. 1998. The influence of sex and body size on food habits of a giant tropical snake, Python reticulatus. Functional Ecology 12: 248-258.

Sibley, D.A. 2017. Sibley Birds East. Field Guide to Birds of Eastern North America. Second edition. Alfred A. Knopf, New York, New York, USA.

Silva Lee, A. 1996. Natural Cuba/Cuba Natural. PANGAEA, Saint Paul, Minneapolis, Minnesota, USA.

Silva[-]Taboada, G. 1979. Los Murciélagos de Cuba. Editorial Academia, La Habana, Cuba.

Silva-Taboada, G. and K.F. Koopman. 1964. Notes on the occurrence and ecology of Tadarida laticaudata yucatanica in Eastern Cuba. American Museum Novitates 2174: 1-6.

Silva[-]Taboada, G., W. Suárez Duque, and S. Díaz Franco. 2007. Compendio de los Mamiferos Terrestres Autóctonos de Cuba Vivientes y Extinguidos. Ediciones Boloña, La Habana, Cuba.

Slip, D.J. and R. Shine. 1988. Feeding habits of the Diamond Python, Morelia s. spilota: Ambush predation by a boid snake. Journal of Herpetology 22: 323-330.

Smith, C.R. 1999. Boa Constrictors (Boa constrictor). Siar Anthranir Reptiles, Austin, Texas, USA.

Tews, J., U. Brose, V. Grimm, K. Tielbörger, M.C., M Schwager, and F. Jeltsch. 2004. Animal species diversity driven by habitat heterogeneity/diversity: the importance of keystone structures. Journal of Biogeography 31: 79-92.

Tolson, P.J. 1987. Phylogenetics of the boid snake genus Epicrates and Caribbean vicariance theory. Occasional Papers of the Museum of Zoology, The University of Michigan 715: 1-59.

Tolson, P. J. 1992. The reproductive biology of the Neotropical boid genus Epicrates (Serpentes: Boidae), pp. 167-178. In: W.C. Hamlett (ed.), Reproductive Biology of South American Vertebrates. Springer-Verlag, New York, New York.

Tolson, P.J. 2012. Battle to the death in the Graffiti Hill arroyo: Cuban anole and boa fight to the end. Anole Annals <http://www.anoleannals.org/2012/11/22/ battle-to-the-death-in-the-graffiti-hill-arroyo/>.

Tolson, P.J. and R.W. Henderson. 1993. The Natural History of West Indian Boas. R\&A Publishing Ltd., Somerset, England.

Tolson, P.J. and R.W. Henderson. 2006. An overview of snake conservation in the West Indies. Applied Herpetology 3: 345-356.

Tolson, P.J. and C. Petersen. 2008. Homing in on hutias at Gtmo: The Navy \& The Toledo Zoo partner to study a leónle-known rodent. Currents Summer 2008: 8-15.

Tolson, P.J., M.A., García, and C.L. Ellsworth. 2007. Habitat use of the Mona Boa (Epicrates monensis monensis) on Isla Mona, West Indies, pp. 118-126. In: R.W. Henderson and P. Powell (eds.), Biology of the Boas and Pythons. Eagle Mountain Publishing, LC, Eagle Mountain, Utah, USA.

Uetz, P., P. Freed, and J. Hošek (eds.). 2020. The Reptile Database. <http://www. reptile-database.org>.

Vareschi, E. and W. Janetzky. 1998. Bat predation by the Yellow Snake or Jamaican Boa, Epicrates subflavus. Jamaica Naturalist 5: 34-35.

Vázquez Milian, A. and E. Nieves Lorenzo. 1980. Aspectos de la Reproducción de la Torcaza Cabeciblanca (Columba leucocephala Linneo) en la EFI "Playa Larga." Unpublished B.Sc. Thesis, Centro Universitario de Pinar del Río, Pinar del Río, Cuba.

Vincent, S.E., A. Herrel, and D.J. Irschick. 2004. Ontogeny of intersexual head shape and prey selection in the pitviper Agkistrodon piscivorus. Biological Journal of the Linnean Society 81: 151-159.

Vincent, S.E., P.-D. Vincent, D.J. Irschick, and J.M. Rossell. 2005. Do juvenile gape-limited predators compensate for their small size when feeding? Journal of Zoology 268: 279-284.

Viña Dávila, N. and L.F. de Armas. 1989. Depredación de Tropidophis melanurus (Serpentes: Tropidophiidae) por Epicrates angulifer (Serpentes: Boidae). Miscelánea Zoológica 41: 2-3.

Vogel, Z. 1965. Herpetologische Beobachtungen auf Kuba (III). Aquarium Terrarium 12: 340-343 (reprinted in Dutch as Herpetologische waarnemingen op Cuba IV. Lacerta 24: 75-77).

Wenner, T.J. 2012. Observation of a Gopher Snake (Pituophis catenifer) constricting a Red-tailed Hawk (Buteo jamaicensis). Journal of Raptor Research 46: 323-324.

Wickham, H. 2016. ggplot2: Elegant Graphics for Data Analysis. Springer-Verlag New York, New York, USA. <https://ggplot2.tidyverse.org>.

Wiley, J.W. 2003. Habitat association, size, stomach content, and reproductive condition of Puerto Rican boas (Epicrates inornatus). Caribbean Journal of 
Science 39: 189-194.

Witmer, G.W. and M. Lowney. 2007. Population biology and monitoring of the Cuban hutia at Guantánamo Bay, Cuba. Mammalia 2007: 115-121.

Wunderle, J.M., Jr. and J.E. Mercado. 2004. Spatial ecology of Puerto Rican Boas
(Epicrates inornatus) in a hurricane impacted forest. Biotropica 36: 555-571.

Yánez-Muñoz, M.H., G.M. Pozo-Zamora, F. Sornoza-Molina, and J. Brito M. 2017. Dos nuevos registros de vertebrados en la dieta de Corallus hortulanus (Squamata: Boidae) en el noroeste de la Amazonia. Cuadernos de Herpetología 31: 41-47.

Appendix I. Summary of the most significant references on the feeding habits of free-ranging Cuban Boas (Chilabothrus angulifer). Asterisks $\left(^{*}\right)$ mark those included in our analyses.

\section{Reference}

Fernández de Oviedo (1851)

Poey (1866)

Gundlach (1875)

Rodríguez (1876)

Gundlach (1880)

Miller (1904)

Barbour (1914)

Barbour and Ramsden (1919)

Schwartz and Ogren (1956)

Hardy (1957)

Silva-Taboada and Koopman (1964)

Vogel (1965)

Sheplan and Schwartz (1974)

Buide (1966)

Silva (1979)

Vázquez and Nieves (1980)

Regalado (1981)
Prey species (number of prey items and growth states)

Stated that as many as 6-7 "guabiniquinax" (= hutias) were frequently found in the stomachs of very large "culebras ó sierpes" (= Ch. angulifer).

Commented on the damage caused by $C h$. angulifer to henhouses and dovecotes; the largest individuals also may prey on piglets; useful when associated with barns because it controls rats; in natural habitats, it consumes hutias and birds.

Ibid.

Ibid.

Ibid.; also commented on the benefits of boas in sugarcane plantations because of the elimination of rodents; recounted the folk story of boas capturing hutias in midair while falling to the ground where they end up coiled around their prey.

Referenced field notes of W. Palmer, who stated that boas were said by the country folk to forage for bats at a cave mouth near Baracoa in eastern Cuba; he did not confirm bat predation.

Ibid.

Made reference to the strong persecution of boas by humans because they prey on chickens, turkeys, and young pigs; referenced Palmer and Riley, who commented on boas that were said by the country folk to forage for bats at the openings of bat caves near Guanajay in western Cuba; also referred to observations of V.J. Rodriguez on a boa foraging for bats in a cave near Maisí in eastern Cuba; they did not confirm bat predation. Observed a boa laying in a low and narrow passage connecting with a chamber containing a large colony of Jamaican Fruit-eating Bats (Artibeus jamaicensis) in a cave at Guajimico, Cienfuegos Province; they did not confirm bat predation.

Reported three boas constricting or swallowing Cuban Flower Bats (Phyllonycteris poeyi) and another two that regurgitated three and nine bats, respectively (same species), from a hot cave at Guanayara, west of Trinidad in central Cuba*; the snakes he studied in that cave $(n=41)$ ranged from four to eight feet in total length (i.e., 1.2-2.4 m), but he did not specify the size of the five snakes he found consuming bats; he was the first to confirm bat predation by Ch. angulifer and by any species of Chilabothrus. Ibid.

"The senior author was assured by local farmers that Cuban boas (Epicrates angulifer) often crawled up to the foliage [of the 'Jata' palm tree, Copernicia x vespertilionum] to eat the bats [Little Goblin Bats, Mormopterus minutus, Broad-eared Bats, Nyctinomops laticaudatus]"; the foliage of this palm tree is frequently used as roosting sites by these two species of bats; the authors did not confirm bat predation.

Mentioned that Ch. angulifer preys on Desmarest's Hutias (Capromys pilorides), bats, bird nests, and domestic fowl.

Reported a boa containing six bats (1 Cuban Fruit-eating Bat, Brachyphylla nana; 2 Antillean Ghost-faced Bats, Mormoops blainvillei; 2 Cuban Flower Bats, Phyllonycteris poeyi; 1 unidentified bat)*; mentioned that the gastrointestinal tracts of other boas examined contained rats (Rattus sp.) or domestic chickens (pullets and half-grown adults) but provided no quantitative data on the latter.

Reported a large boa (3.35 m total length) killed on the Hicacos Peninsula, north of Matanzas Province, which contained a young domestic goat, Capra hircus (ca. 7 lbs.)*; commented on the abundance of Desmarest's Hutias (Capromys pilorides) in the area as potential prey.

Same as Hardy (1957) and Silva-Taboada and Koopman (1964); also mentioned finding boas in the foliage of the "Jata" palm tree where two bat species (Little Goblin Bat and Broad-eared Bat) roost and presented a photograph of several boas presumably moving to assume foraging positions in a cave at Guanayara (see Hardy 1957) prior to the bat exodus.

Mentioned Ch. angulifer as a predator of White-crowned Pigeon (Patagioenas leucocephala) chicks in nesting colonies located east of Jagüey Grande, Matanzas Province.*

Listed $C h$. angulifer among what he considered occasionally harmful native species, since it preys on domestic animals. 
Reference

Buide (1985)

Buide (1986)

Godínez et al. (1987)

Viña and Armas (1988)

Rams et al. (1989)

Sampedro and Motañez (1989)

Schwartz and Henderson (1991)

Cruz (1992)

Godínez (1993)

Tolson and Henderson (1993)

Estrada (1994)

Silva (1996)

Mancina and Llanes (1997)

Sampedro (1998)

Legón (1998)

Alberts et al. (2001)

Alonso and Rodríguez (2003)

Chamizo et al. (2003)

Rodríguez and Rodríguez (2003)

Holanova and Hribal (2004)

Fong et al. (2005)

Hernandez and Pimentel (2005)

P.J. Tolson in Tolson and Henderson (2006)

Petersen et al. (2007)

Witmer and Lowney (2007)

Tolson and Petersen (2008)
Prey species (number of prey items and growth states)

Made reference to hutias, rats, birds, and bats as prey of $C h$. angulifer.

Ibid.

Mentioned Ch. angulifer as a predator of White-crowned Pigeon (Patagioenas leucocephala) chicks and eggs in a nesting colony on the Guanahacabibes Peninsula, Pinar del Río Province.*

Reported a boa slightly in excess of $1.0 \mathrm{~m}$ total length swallowing a Giant Trope (Tropidophis melanurus), $0.42 \mathrm{~m}$ in total length, tail-first, in Santiago de Cuba Province.*

Listed Ch. angulifer among the potential predators of the Cuban Solenodon (Solenodon cubanus).

Reported a boa preying on a Cuban Slider (Trachemys decussata) nest in the Zapata Swamp, Matanzas Province.

Stated that $C h$. angulifer is a sit-and-wait forager as an adult; diet includes domestic fowl, a number of bat species (probably based on Hardy 1957; Sheplan and Schwartz 1974), and rodents (Capromys, Rattus); mentioned anoles and native birds as potential prey.

Mentioned Ch. angulifer as a bat predator in hot caves and briefly described foraging behavior, stating that boas take advantage of concentrations of bats, capturing them on the wing as they emerge from or return to caves.

Same as Godínez et al. (1987) (in litt. 4.iv.2020).

Reported a boa (ca. $1.5 \mathrm{~m} \mathrm{SVL}$ ) constricting a House Rat (Rattus rattus) by day in a sewer (in complete darkness) in an old fort on the U.S. Naval Base at Guantánamo Bay (P.J. Tolson in litt. 23.iii.2020); noted that neonates of most other species of Chilabothrus prefer lizards as food, whereas neonatal Cuban Boas readily accept small rodents.

Commented that those boas that survive for any length of time in human-altered habitats feed mostly on domestic animals such as poultry, for which they are seen as nuisance animals by most country people, who kill them whenever encountered.

Same as Buide (1985).

Provided compelling evidence of predation by a boa $(<2.0 \mathrm{~m} \mathrm{SVL})$ on two Cave Swallow (Petrochelidon fulva) eggs (C.A. Mancina, pers. comm. 19.v.2020).*

Same as Sampedro and Motañez (1989); also noted that, when first seen, the boa (ca. $2.0 \mathrm{~m}$ total length) had a live hatchling turtle in its mouth (in litt. 6.xii.2015).*

Same as Rams et al. (1989).

Mentioned Ch. angulifer as potential predator of birds, bats, lizards, and hutias (Capromys pilorides), emphasizing predation on hutias.

Listed Ch. angulifer among the potential predators of cave-dwelling frogs of the genus Eleutherodactylus. Same as Poey (1866) and Buide (1985).

Stated that $C h$. angulifer is persecuted and killed because it occasionally preys on poultry.

Stated that the smaller Cuban Boas prey on sleeping anoles in a context suggesting that they might be among the predators of the Pinar del Rio Cliff Anole (Anolis bartschi); this record by J. Hribal was based on a young boa observed at night preying on an undetermined species of anole near a cave in the area of Viñales, Pinar del Río Province (V. Holanova, in litt. 6.iv.2020).*

Same as Rodríguez and Rodríguez (2003).

Reported a boa (1.7 m total length) containing a Desmarest's Hutia (Capromys pilorides) (1.9 kg) in the region of "Mil Cumbres," Pinar del Río Province.*

Stated that every adult Ch. angulifer examined (on the US Naval Base at Guantánamo Bay) contained Desmarest's Hutia (Capromys pilorides) hair in its feces.

Mentioned Ch. angulifer as predator of birds, bats, lizards, and Desmarest's Hutias (Capromys pilorides), emphasizing predation on hutias.

Mentioned Ch. angulifer as a predator of Desmarest's Hutias (Capromys pilorides).

Presented a photograph of a large boa constricting a Desmarest's Hutia (Capromys pilorides) at Cuzco Beach on the U.S. Naval Base at Guantánamo Bay; the predation event was observed in a grassy area early in the morning (P.J. Tolson, in litt. 28.iii.2020).*

P.J. Tolson in Henderson and Powell (2009)

Same as P.J. Tolson in Tolson and Henderson (2006).

Arredondo (2011)

Borroto-Páez (2011a)
Mentioned Ch. angulifer as a potential predator of hutias, solenodons, small sloths, and primates in the past.

Presented a photograph of a boa $(<2.0 \mathrm{~m} \mathrm{SVL})$ constricting a House Rat $(R$. rattus) by day in "La Barca Cave”, Guanahacabibes Peninsula, Pinar del Río Province (in litt. 25.v.2020)*; also mentioned Ch. angulifer among predators of House Mice (Mus musculus). 


\section{Reference}

Mancina (2011)
Prey species (number of prey items and growth states)

Presented a photograph of a boa $(<2.0 \mathrm{~m} \mathrm{SVL})$ constricting a Cuban Fruit-eating Bat (Brachyphylla nana) by day in "La Barca Cave", Guanahacabibes Peninsula, Pinar del Río Province (pers. comm. 19.v.2020)*; briefly described foraging behavior in cave-associated Ch. angulifer, stated that boas may use two basic foraging modes, either hanging down from rock projections or crevices and taking a position on the ground close to the hot chambers.

Amaro (2011) Summarized previous records from the literature.

Polo and Rodríguez (2012) Summarized previous records from the literature.

Tolson (2012)

Segovia et al. (2013)

Rodríguez-Cabrera et al. (2015)

Reported entwined skeletons of a juvenile boa and a Green-blotched Giant Anole (Anolis smallwoodi) suggesting that the encounter was lethal for both participants.*

Reported a boa (ca. $2.0 \mathrm{~m}$ total length) preying upon a nestling Gray Kingbird (Tyrannus dominicensis) over one hour before sunrise in the "Siboney-Jutici" Ecological Reserve, Santiago de Cuba Province.*

Reported predation on six bats (three juvenile Buffy Flower Bats [Erophylla sezekorni] and three adult Cuban Flower Bats [Phyllonycteris poeyi]) by four juvenile boas*; one of these boas, the smallest ever reported, had captured an adult Cuban Flower Bat on the wing; three other small boas were observed foraging for bats in caves; four of these boas had visible umbilical scars.

Rodríguez-Cabrera et al. (2016a)

Reviewed on the role of Ch. angulifer and other large species of Chilabothrus as top predators in the West Indies; also presented photographs of a large boa containing a Desmarest's Hutia (Capromys pilorides), which is included in this report as Fig. 8 (left).

Dinets (2017) Reported predation on 31 Jamaican Fruit-eating Bats (Artibeus jamaicensis) by nine boas (1.1-2.1 m total length, visually estimated) in a sinkhole cave in "Desembarco del Granma" National Park, Granma Province; five boas captured four bats each, three boas got three bats each, and one boa got two bats (in litt. 4.v.2020)*; he observed foraging activity both after sunset and before dawn and noted that boas tended to aggregate during foraging periods and that this apparently increased capture success, which suggested coordinated hunting. 